Earth Syst. Sci. Data Discuss., https://doi.org/10.5194/essd-2018-64

Manuscript under review for journal Earth Syst. Sci. Data

Discussion started: 27 July 2018

(c) Author(s) 2018. CC BY 4.0 License.

(c) (i)

\title{
GMED: Global Marine Environment Datasets for environment visualisation and
} species distribution modelling

Zeenatul Basher ${ }^{1 *}$ David A. Bowden ${ }^{2}$, and Mark J. Costello ${ }^{1}$

${ }^{1}$ Institute of Marine Science, The University of Auckland, Auckland 1142, New Zealand

${ }^{2}$ Coasts and Oceans Centre, National Institute of Water and Atmospheric Research (NIWA), Private Bag

14901, Wellington, New Zealand

${ }^{*}$ Corresponding author:

Zeenatul Basher

Email address: z.basher@auckland.ac.nz 
Earth Syst. Sci. Data Discuss., https://doi.org/10.5194/essd-2018-64

Manuscript under review for journal Earth Syst. Sci. Data

Discussion started: 27 July 2018

(c) Author(s) 2018. CC BY 4.0 License.

(c) (i)

\section{Abstract}

23 The Global Marine Environment Datasets (GMED) is a compilation of publicly available

24 climatic, biological and geophysical environmental layers featuring present, past and future

25 environmental conditions. Marine biologists increasingly utilize geo-spatial techniques with

26 modelling algorithms to visualize and predict species biodiversity at a global scale. Marine

27 environmental datasets available for species distribution modelling (SDM) have different

28 spatial resolutions and are frequently provided in assorted file formats. This makes data

29 assembly one of the most time-consuming parts of any study using multiple environmental

30 layers for biogeography visualization or SDM applications. GMED covers the widest available

31 range of environmental layers from a variety of sources and depths from the surface to the

32 deepest part of the ocean. It has a uniform spatial extent, high-resolution land mask (to

33 eliminate land areas in the marine regions), and high spatial resolution (5 arc-minute, c. $9.2 \mathrm{~km}$

34 near equator). The free public online availability of GMED enables rapid map overlay of

35 species of interest (e.g. endangered or invasive) against different environmental conditions of

36 the past, present and the future, and expedites mapping distribution ranges of species using

37 popular SDM algorithms. GMED can be found at http://gmed.auckland.ac.nz/ (DOI: https://

38 10.6084/m9.figshare.5937268) 


\section{Introduction}

Understanding how species distributions are related to environmental gradients is important for assessing the impacts of, for instance, threats to habitats from species invasions, and climate change (Millennium Ecosystem Assessment, 2005). Because sampled data on species’ distributions are spatially biased (Phillips et al., 2009), species distribution models (Anderson et al., 2003), which predict the occurrence of suitable habitat based on correlations between species' records and environmental parameters (Elith and Leathwick, 2009), are used increasingly to predict distributions in un-sampled areas based on environmental variables. SDM's have a wide variety of uses in biogeography, ecology and conservation biology (Elith and Leathwick, 2009). Successful prediction of species ecological niche preference using SDM algorithms depends on both high-quality species occurrence records and related environmental information (Elith and Leathwick, 2009). In contrast to the wide adoption of SDM in terrestrial ecosystem studies, there are relatively fewer studies of marine species (Robinson et al., 2011). Predictions of geographic distributions of marine organisms using SDM include studies on fish (Guinotte et al., 2006; Wiley et al., 2003), coral reefs (Bridge and Guinotte, 2013; Davies and Guinotte, 2011; Rinne et al., 2014; Tittensor et al., 2009; Tong et al., 2013), jellyfish (Bentlage et al., 2013), crabs (Compton et al., 2010), benthic invertebrates (Basher et al., 2014; Basher and Costello, 2016; Compton et al., 2013; Dambach et al., 2012; Reiss et al., 2011; Saeedi et al., 2016), and algae (Downie et al., 2013; Graham et al., 2007; Tyberghein et al., 2012; Verbruggen et al., 2009). Application of SDM in the marine realm were restricted by issues compared with the terrestrial environment are the fewer marine species observation records (Kaschner et al., 2006), extensive spatio-thermal variability characterizing the ocean environment (Franklin and Miller, 2009; Valavanis et al., 2008), and complexities involved in processing environmental data for SDM applications (Tyberghein et al., 2012).

Marine environmental data are derived from direct measurement, remote-sensing, and numerical modelling for a range of variables associated with the ocean surface (e.g. currents, wave height), water column (e.g. temperature, salinity, nutrients), and sea floor (e.g. depth, slope, distance to shore) (Valavanis et al., 2008). Because available marine environmental datasets occur in assorted file formats and differ in their accuracy, and temporal and spatial resolution, it is common for a large portion of time in SDM studies to be spent on assembling compatible environmental data (Tyberghein et al., 2012). Among the commonly available marine environmental datasets, sea surface temperature observations are relatively consistent, accurate, well spatially resolved and have a long global time series. Chlorophyll-a 
73 concentration has similarly good consistency apart from data gaps in the polar-regions, but has

74 only been available at global scales since 1997. In contrast, most of the deep-sea (i.e., below 75 surface layers) and less well sampled variables (e.g. dissolved oxygen and nutrient 76 concentrations) are patchy in their spatial distribution and cannot be measured from satellite

77 imagery. Generally, data accuracy will be poorer from more remote areas, which have less

78 primary data. Hence, continuous, global, layers for such variables are predicted from ocean

79 circulation models and by extrapolation of in situ sample data. Ocean circulation models

80 generally have relatively coarse resolution, primarily because of computational capacity, and

81 thus are often inadequate to gather environmental conditions on finer time and spatial scales

82 (Redfern et al., 2006). However, when available at finer resolution, ocean circulation models

83 can simulate realistic features and dynamics, such as variability in frontal and eddy structures and its effect on biogeochemical fields (McGillicuddy et al., 2003).

WorldClim (http://www.worldclim.org), a global terrestrial climate environment dataset is a freely available and widely accessible online repository that has served the need for terrestrial SDM researchers. Initiatives to establish equivalent marine environment data repositories include (1) the KGS mapper environmental dataset (Hexacoral project, Fautin and Buddemeier, 2011), (2) Aquamaps (Kaschner et al., 2008), (3) the human impact on marine ecosystems layers (Halpern et al., 2008), (4) Bio-Oracle (Tyberghein et al., 2012), and (5) MARSPEC: Ocean climate layers for marine spatial ecology (Sbrocco and Barber, 2013). However, except for Bio-Oracle, other datasets have not been widely adopted due to the complexity of processing the data for modelling applications. Although Bio-Oracle has the greater number of independent variables among the datasets, it lacks bathymetry and other ecologically significant layers (e.g. slope) (Table 3). The accuracy and resolution of various ocean circulation models and survey data are continually increasing, particularly through assimilation of observations from global ocean observing programmes. Millions of marine species observation records are available from the Global Biodiversity Information Facility (GBIF, http://www.gbif.org) and Ocean Biogeographic Information Systems (OBIS, http://www.iobis.org). A need for easier access to marine species occurrence records and environmental data prompted the science community to launch the Group on Earth BON, https://www.earthobservations.org/geobon.shtml (Andrefouet et al., 2008), which aims to consolidate biodiversity and earth observation data in a more readily accessible form. 
considerable work is needed to collate and match environmental data layers from disparate sources. Based on this experience, we have developed an extensive on-line repository of marine environmental data layers with consistent resolution and global coverage that are ready to use in SDM and other spatial analyses. The repository is called the Global Marine Environment Dataset (GMED). This paper describes the source data and procedures used to generate GMED.

\section{Methods}

Development of the GMED layers followed three main steps: (1) compilation, quality control, and land-masking of source data; (2) interpolation and projection to generate continuous data surfaces at uniform resolution; and (3) evaluation of derived data layers against source data (Fig. 1).

\subsection{Source data}

We compiled data from in situ measured, remote-sensed, and modelled datasets for a broad range of quantitative environmental variables (Table 1). We extracted spatially interpolated in situ measured and remotely sensed data from Aquamaps (Kaschner et al., 2008), KGS mapper environmental data (Hexacoral project, Fautin and Buddemeier, 2011), NOAA Ocean Color (Feldman and McClain, 2009), and World Ocean Database 2009 (Boyer et al., 2009). Modelled datasets were sourced from Bio-Oracle (Tyberghein et al., 2012), paleoclimatic reconstructions from Peltier (1993) and Paul \& Schafer-Neth (2003) and IPCC future climatology layers from Jungclaus (2006), Tyberghein et al. (2012), and Kaschner et al.(2013). All compiled datasets were converted into ESRI grid format before adding into ArcMap workspace for further processing. Several of the deep-sea variables (e.g., bottom salinity, nutrients) had marine pixels with 'no data' value. We calculated these missing pixel values using the 'raster calculator' in ArcGIS, as the average value of the 12 surrounding (ocean) cells. Variable values were then extracted from each raster grid into a single, global, five arc-minute point geo database. A uniform land mask was then applied by extracting high-resolution land area from GEBCO 30 arc-second bathymetry (IOC et al., 2003) (Fig. 1).

\subsection{Interpolation and projection}

Methods used to produce smooth interpolated environmental surfaces may combine regression analyses and distance-based weighted averages (Hartkamp et al., 1999). Such approaches 
141 include: Gaussian weighting filter (Thornton et al., 1997), PRISM method (Daly et al., 2002),

142 Spline (Hijmans et al., 2005; New et al., 2002) and Inverse Distance Weighting and Kriging

143 (see Hartkamp et al., 1999, for an overview). We used Inverse Distance Weighting (IDW)

144 multivariate interpolation (Daly, 2006; Shepard, 1968) to generate environmental surfaces

145 using the "Spatial Analyst" extension in ArcGIS 10. We selected IDW instead of other

146 interpolation techniques because it is computationally efficient and its ability to interpolate

147 equal distance points has been demonstrated in other studies (Dirks et al., 1998; Joseph and

148 Kang, 2011; Lu and Wong, 2008). IDW interpolates environmental surfaces based on

149 surrounding measured values that determine the smoothness of the resulting surface

150 (interpolated values are decreased by distance weighting). In contrast, kriging, the other

151 commonly used method produces environmental surface based on statistical models and is

152 more suitable for capturing fine-scale local variability (Gong et al., 2014). IDW interpolation

153 was used with the default smoothing option in Spatial Analyst $(p=2)$, which assigns the final

154 interpolated cell values as weighted averages of the values of 12 surrounding points.

155 Most currently-available datasets are provided in equidistant projections (same distance

156 from north to south in any pixel of the map). This may be suitable for some mapping

157 applications, however to measure species richness, abundance and density estimate in a

158 particular region, an equal-area projected (same area in any pixel of the map) dataset is

159 preferred (Elith et al., 2010; Tittensor et al., 2009). Following Tyberghein et al (2012), GMED

160 environmental rasters were interpolated into Behrmann equal area projection as well as WGS84

161 world geographic equidistant projection. Both equal area and geographically projected data

162 layers were converted into ASCII grid format before making them available for downloading

163 from the GMED website (Fig. 1). A spatially cropped version of the dataset is also generated

164 by cropping the northern extent of the dataset at $70^{\circ} \mathrm{N}$ because of limited sample data in the

165 Arctic.

\subsection{Descriptive statistics}

In ArcGIS, the "band statistics" tool was used to measure the standard deviation, standard error, and coefficient of variation of each dataset. The same tool was used to calculate Pearson

170 correlation coefficients $(r)$ for all pairwise comparisons between pixels in the datasets. To

171 compare GMED with other available datasets we calculated the range of values for depth,

172 temperature, salinity, and chlorophyll- $a$ annual mean based on a $0.5^{\circ}$ resolution grid. We

173 compared mean values of the above variables with KGS Environment Dataset (Fautin and

174 Buddemeier, 2011) and AquaMaps dataset (Kaschner et al., 2008). 
Earth Syst. Sci. Data Discuss., https://doi.org/10.5194/essd-2018-64

Manuscript under review for journal Earth Syst. Sci. Data

Discussion started: 27 July 2018

(c) Author(s) 2018. CC BY 4.0 License.

(c) (i)

\subsection{Quality assurance of interpolated data layers}

177 All of the primary datasets used in the GMED compilation had undergone quality control

178 checks by the primary data collectors and processors (Table 1). Here, we checked the

179 interpolation quality of the generated layers to ensure that no errors were introduced during

180

181

182

183

184

185

186

187

188

189

190

191 the re-interpolation process. We tested the interpolation quality for all of the data layers by extracting interpolated values from 10,000 randomly generated evaluation points over the global ocean area using the 'extract to points' tool in the ArcGIS 'Spatial Analyst' extension. Coefficient of variations and standard errors of individual data layers were then calculated from this point grid using the 'pastecs’ package in R v2.15 (R Core Team, 2014) and compared with values for these statistics derived from the original source layers (Table 1) to ensure no significant error was introduced with the interpolation process.

\section{Results}

After initial data cleaning, the primary GMED point grid had ca. 5.7 million data points. Sixty global marine environment rasters were generated from these point records (Table 1). A detailed description of the data layers, their sources and interpolated surface images are available in the supporting materials sections (Table S2 and Appendix A).

\subsection{Comparison with other datasets}

Differences were observed in extreme values by comparison with the source datasets. For instance, the GMED depth layer has maximum values of $10,415 \mathrm{~m}$, compared to $8,672 \mathrm{~m}$ in KGS Mapper and 8,586 m in AquaMaps (Fig. 2), and 10,977 m in a statistical analysis of marine bathymetry (Costello et al., 2010; Costello et al., 2015). The sea surface temperature (mean) layer has values ranging between -1 and $31^{\circ} \mathrm{C}$, compared to KGS Mapper (-1.9 to 29.9 ${ }^{\circ} \mathrm{C}$ ) and AquaMaps (-1.79 to $29.57^{\circ} \mathrm{C}$ ). Maximum values were also higher in GMED than other two datasets for Salinity (41 versus 40.3 and 40.02 PSS). In contrast, the maximum value of chlorophyll-a in GMED was between the values of other two datasets (60.3 versus 64.5 and 56.7 mg.m ${ }^{-3}$ ) (Fig. 3).

\subsection{Interpolation quality validation with source data}

Interpolation error of GMED's environment surface by comparison with the source data layers was minimal, as assessed by consistent standard errors and coefficients of variation across most 
209 of the datasets when verified using the random evaluation points (See Fig. S1 for details).

210 Depth, LGM depth, and primary productivity datasets showed higher standard error in the

211 GMED evaluation data than in the source datasets. These increases were probably due to

212 downgrading the spatial resolution of the interpolated surface into GMED's standard five arc-

213 minute resolution from their primary data resolution of 30 arc-second. Visual inspection of the

214 original source data layers revealed that the Arctic had more data gaps compared to the

215 Antarctic, which caused interpolation errors to be more visible in the higher latitudes of

216 northern hemisphere, especially above $70^{\circ} \mathrm{N}$ latitude (Appendix A Visualizations).

\section{Discussion}

219 GMED has 6 to 12 times higher spatial resolution than most previously available major marine environment datasets, with the exception of Bio-Oracle, which is at the same resolution. However, GMED has 30 more data layers than Bio-Oracle (Table 1 and Table 3). GMED environmental surfaces were also derived from a more diverse set of sources than any other publicly available data. Applications such as analyses of species’ population densities will benefit from equal-area projected dataset while rapid mapping of species will benefit from more the commonly-used geographically projected equidistant dataset. The inclusion of depth, slope, and several deep-sea variables with past and future climatic scenario layers in GMED will enable researchers to model distributions of species across broad spatial and temporal scales. We will integrate more data layers with GMED from climatic, anthropogenic variables and modelled datasets as they become available in the future.

\subsection{Comparison with other datasets}

Existing marine environment datasets were compiled for specific objectives. For example, AquaMaps, datasets represented long-term average of temporally varying environmental variables (Ready et al., 2010). The KGS mapper marine datasets were developed to enable environmental classification and to understand spatial and temporal patterns in biogeochemistry and biogeography (Guinotte et al., 2006). The Bio-Oracle dataset was developed to facilitate modelling the distribution of shallow water marine species (Tyberghein et al., 2012). Differences were observed in extreme values of GMED variables by comparison with the source datasets. These effects were likely the result of the source data of these layers being at higher spatial resolution than the source data of other datasets. As SDM results tend to be influenced by correlated environmental factors (Jiménez-Valverde et al., 2009), depending on the research questions researchers could use the Table S2 to decide on which 
variables to use for their study to minimize this confounding correlation effect. GMED provides the most comprehensive environmental dataset resource to date for support of SDM applications. Table 3 gives a comparison of strengths and weaknesses of GMED by comparison with other freely available marine environment datasets.

\subsection{Dataset extent and quality}

The comparatively high spatial resolution of GMED does not indicate that data quality is necessarily high in all locations. The quality of the interpolated environmental surfaces is, therefore, spatially variable and depends on local environmental variability and the quality and density of the underlying raw observation datasets. GMED environmental surfaces may not capture all the variation that occur at a resolution of $9 \mathrm{~km}$ considering the overall low density of real-time ocean observations for most variables, and thus not capturing locally important drivers such as fine scale bathymetric or environmental conditions.

The data layers derived from remotely sensed data included only information with the highest available quality (from Level-3 processed data products, see Hooker and McClain, 2000 for details). However, even here, data gaps exist due to patchy temporal sampling of ocean colour by MODIS and SeaWiFS sensors, sparse observational networks in the polar regions (IPCC Climate Change, 2007), clouds, thick aerosols, inter-orbit gaps, sun glint, and high solar zenith angles (Gregg and Casey, 2007). Filling these data gaps by interpolation makes them disappear but may lead to unpredictable errors. The overall interpolation error was small (Fig. S1), and the highest uncertainty (i.e. the highest predicted error) was in regions with low data coverage at high latitudes in the Arctic, and some regions of Antarctica (Fig. S2) (Kennedy, 2014). For example, chlorophyll-a, photosynthetically available radiation, and diffuse attenuation, which are measured at relatively short wavelengths (in the visible spectrum), cannot be accurately measured during the winter season at high latitudes due to high solar zenith angles (Gregg and Casey, 2007). Surface temperature data do not suffer from this effect because they are measured in longer wavelengths (the thermal infrared part of the spectrum). Errors are also visible in some non-sampled areas in the middle of the oceans, particularly for the less commonly reported variables e.g. the deep-sea and nutrient variables (see layer visualization on Appendix A). Although interpolation and extrapolation of data for pixels with missing data could create bias affecting the quality of interpolation with layers created using remotely sensed data, our verification data indicates that the GMED layers are reliable representations of the source data (Fig. S1). 
The extent to which missing data could create a problem in analyses depends on the application. The larger uncertainty in the prediction of areas with missing pixels may be offset by a stronger gradient of dominant variables. We provide a cropped version $\left(70^{\circ} \mathrm{N}\right.$ top extent) of the GMED dataset as well as a full version of dataset covering all latitudinal ranges. We advise use of the cropped version of the dataset for any modelling exercise; the full extent dataset should only be used with careful consideration of possible potential model anomalies in the Polar Regions.

Although there was an overall agreement between all marine datasets in the tropical and sub-tropical regions, differences shown in interpolated surface near the polar and coastal areas were still large. This clearly indicates that some uncertainty exists about the true values of any particular grid cell in these areas. The differences we found likely reflect the difference between a pure statistical and a more mechanistic expert-driven approach in interpolation. Future work focusing on model comparison in these geographic areas would be useful because in our comparison the effects of interpolation method may be confounded with differences in primary dataset resolution, used climate and depth data sources, and the temporal resolution of datasets.

Marine species distribution models are susceptible to faulty predictions into land areas when the underlying environmental data does not have a uniform land area. As we masked the GMED datasets using land areas extracted from the very high-resolution (30 arc-second, ca. $930 \mathrm{~m}$ in equator) GEBCO data, model prediction in coastal areas should minimise such errors. We made all data available ASCII Grid format, frequently used by common SDM algorithms (e.g. MaxEnt, Random Forest, GARP). GMED is published in 5 arc-min (c. 9.2 km near equator) resolution affording, (1) convenience of managing the rasters in common desktop computing environments, (2) having sufficient resolution to model near-shore environments, and (3) resolution fine enough to address species distribution questions at a global scale for implementing management decisions.

\section{Data availability}

Full dataset in individual data layers with most recent updates are always available at:

http://gmed.auckland.ac.nz/

A snapshot associated with this manuscript stored at

DOI: https://doi.org/10.6084/m9.figshare.5937268 
Earth Syst. Sci. Data Discuss., https://doi.org/10.5194/essd-2018-64

Manuscript under review for journal Earth Syst. Sci. Data

Discussion started: 27 July 2018

(c) Author(s) 2018. CC BY 4.0 License.

(c) (i)

\section{Versions}

312

313

3142.0 Six new data layers added to the repository (Aspects, Port Distance, Euphotic Layer

315 Bottom Depth, Total Suspended Matter, Particulate Organic Carbon, and Particulate

316 Inorganic Carbon)

317

318

319

320

321

322

323

324

325

326

327

328

329

330

331

332

333

334

\section{Conclusions}

We have compiled a comprehensive collection of 60 high-resolution marine environmental data rasters, including layers representing the present, the Last Glacial Maximum, and future climate scenario of year 2100. It is a freely available resource for marine species distribution modelling and visualization applications. Its spatial resolution is 5 arc-min latitude-longitude, which approximates to about $9.2 \mathrm{~km} \times 9.2 \mathrm{~km}$ at equator. The gridded rasters are available for download from the GMED website (http://gmed.auckland.ac.nz/). As more data become available the collection should be expanded. GMED represents significant progress towards the compilation of global scale marine environment data for users, particularly non-specialists in such data such as biologists and ecologists. It enables users to rapidly overlay maps of past, present and future environmental data on the distribution of species, and to use SDM to predict potential distributions of vulnerable, endangered or invasive species. We welcome any potential collaboration and contribution of new global data layers to GMED in future from other researchers. 
Earth Syst. Sci. Data Discuss., https://doi.org/10.5194/essd-2018-64

Manuscript under review for journal Earth Syst. Sci. Data

Discussion started: 27 July 2018

(c) Author(s) 2018. CC BY 4.0 License.

(c) (i)

\section{Author Contributions}

336

337 ZB conceptualized the idea, compiled the data and created the figures. ZB prepared the 338 manuscript with contribution from DB and MC. All authors contributed to the database

339 compilation, analysis and editing of the manuscript.

340

341

342

343 The research was funded by the New Zealand Government under the New Zealand

344 International Polar Year-Census of Antarctic Marine Life Project (IPY2007-01), a University

345

346

347

348

349

350

351

352

353

354

\section{Acknowledgements} of Auckland Doctoral Scholarship, and New Zealand Ministry of Business Innovation and Employment project CO1X1226. We gratefully acknowledge project governance during IPY200701 by the Ministry of Primary Industries Science Team and the Ocean Survey 20/20 CAML Advisory Group (Land Information New Zealand, Ministry of Primary Industries, Antarctica New Zealand, Ministry of Foreign Affairs and Trade, and National Institute of Water and Atmosphere Ltd). This is publication is a contribution to Group on Earth Observations - Biodiversity Observations Network. 


\section{References}

Anderson, R. P., Lew, D., and Peterson, A. T.: Evaluating predictive models of species' distributions: criteria for selecting optimal models, Ecol Model, 162, 211-232, 2003.

Andrefouet, S., Costello, M. J., Faith, D. P., Ferrier, S., Geller, G. N., Höft, R., Jürgens, N., Lane, M. A., Larigauderie, A., Mace, G. M., Miazza, S., Muchoney, D., Parr, T., Pereira, H. M., Sayre, R., Scholes, R. J., Stiassny, M. L. J., Turner, W., Walther, B. A., and Yahara, T.: The GEO Biodiversity Observation Network Concept Document. GEO - Group on Earth Observations, Geneva, Switzerland, 45 pp., 2008.

Balch, W. M., Gordon, H. R., Bowler, B. C., Drapeau, D. T., and Booth, E. S.: Calcium carbonate measurements in the surface global ocean based on Moderate-Resolution Imaging Spectroradiometer data, Journal of Geophysical Research: Oceans, 110, 2005.

Basher, Z., Bowden, D. A., and Costello, M. J.: Diversity and distribution of deep-sea shrimps in the Ross Sea region of Antarctica, PLoS ONE, 9, e103195, 2014.

Basher, Z. and Costello, M. J.: The past, present and future distribution of a deep-sea shrimp in the Southern Ocean, PeerJ, 4, e1713, 2016.

Becker, J., Sandwell, D., Smith, W., Braud, J., Binder, B., Depner, J., Fabre, D., Factor, J., Ingalls, S., and Kim, S.: Global bathymetry and elevation data at 30 arc seconds resolution: SRTM30_PLUS, Marine Geodesy, 32, 355-371, 2009.

Bentlage, B., Peterson, A. T., Barve, N., and Cartwright, P.: Plumbing the depths: extending ecological niche modelling and species distribution modelling in three dimensions, Global Ecol Biogeogr, 22, 952-961, 2013.

Bintanja, R., van de Wal, R. S. W., and Oerlemans, J.: Modelled atmospheric temperatures and global sea levels over the past million years, Nature, 437, 125-128, 2005.

Bouvet, M., Hoepffner, N., and Dowell, M. D.: Parameterization of a spectral solar irradiance model for the global ocean using multiple satellite sensors, J Geophys Res-Oceans, 107, 8-18, 2002.

Boyer, T. P., Antonov, J. I., Baranova, O. K., Garcia, H. E., Johnson, D. R., Locarnini, R. A., Mishonov, A. V., O’Brien, T. D., Seidov, D., Smolyar, I. V., and Zweng, M. M.: World Ocean Database 2009. WOD2009, U.S. Government Printing Office, Washington D.C., 2009.

Bridge, T. and Guinotte, J.: Mesophotic coral reef ecosystems in the Great Barrier Reef World Heritage Area: their potential distribution and possible role as refugia from disturbance, Great Barrier Reef Marine Park Authority, Townsville, Australia1921682760, 41 pp., 2013.

Cavalieri, D. J., Parkinson, C. L., and Vinnikov, K. Y.: 30-Year satellite record reveals contrasting Arctic and Antarctic decadal sea ice variability, Geophys Res Lett, 30, 2003.

Compton, T. J., Bowden, D. A., Roland Pitcher, C., Hewitt, J. E., and Ellis, N.: Biophysical patterns in benthic assemblage composition across contrasting continental margins off New Zealand, $\mathrm{J}$ Biogeogr, 40, 75-89, 2013.

Compton, T. J., Leathwick, J. R., and Inglis, G. J.: Thermogeography predicts the potential global range of the invasive European green crab (Carcinus maenas), Diversity and Distributions, 16, 243255, 2010. 
Earth Syst. Sci. Data Discuss., https://doi.org/10.5194/essd-2018-64

Manuscript under review for journal Earth Syst. Sci. Data

Discussion started: 27 July 2018

(c) Author(s) 2018. CC BY 4.0 License.

Conkright, M. E., Locarnini, R. A., Garcia, H. E., O’Brien, T. D., Boyer, T. P., Stephens, C., and Antonov, J. I.: World Ocean Atlas 2001: Online Edition at http://www.nodc.noaa.gov/OC5/WOA01/pr_woa01.html. World Ocean Atlas 2001, NOAA Oceanographic Data Center, Silver Spring, MD, 2002.

Costello, M. J., Cheung, A., and De Hauwere, N.: Topography statistics for the surface and seabed area, volume, depth and slope, of the world's seas, oceans and countries, Environmental Science and Technology, 44, 8821-8828, 2010.

Costello, M. J., Smith, M., and Fraczek, W.: Correction to surface area and the seabed area, volume, depth, slope, and topographic variation for the world's seas, oceans, and countries, Environmental science \& technology, 49, 7071-7072, 2015.

Da Silva, A., Young, A. C., and Levitus, S.: Atlas of Surface Marine Data Volume 1: Algorithms and Procedures, number 6, 1994. Available at: http://iridl.ldeo.columbia.edu/SOURCES/.DASILVA/.SMD94/.halfbyhalf/, 1994.

Daly, C.: Guidelines for assessing the suitability of spatial climate data sets, International Journal of Climatology, 26, 707-721, 2006.

Daly, C., Gibson, W. P., Taylor, G. H., Johnson, G. L., and Pasteris, P.: A knowledge-based approach to the statistical mapping of climate, Clim Res, 22, 99-113, 2002.

Dambach, J., Thatje, S., Rödder, D., Basher, Z., and Raupach, M. J.: Effects of Late-Cenozoic glaciation on habitat availability in Antarctic benthic shrimps (Crustacea: Decapoda: Caridea), PLoS ONE, 7, e46283, 2012.

Davies, A. J. and Guinotte, J. M.: Global Habitat Suitability for Framework-Forming Cold-Water Corals, PLoS ONE, 6, e18483, 2011.

Dirks, K. N., Hay, J. E., Stow, C. D., and Harris, D.: High-resolution studies of rainfall on Norfolk Island: Part II: Interpolation of rainfall data, J Hydrol, 208, 187-193, 1998.

Doerffer, R. and Schiller, H.: The MERIS Case 2 water algorithm, Int J Remote Sens, 28, 517-535, 2007.

Downie, A.-L., von Numers, M., and Boström, C.: Influence of model selection on the predicted distribution of the seagrass Zostera marina, Estuarine, Coastal and Shelf Science, 121-122, 8-19, 2013.

Elith, J., Kearney, M., and Phillips, S.: The art of modelling range-shifting species, Methods in Ecology and Evolution, 1, 330-342, 2010.

Elith, J. and Leathwick, J. R.: Species Distribution Models: Ecological explanation and prediction across space and time, Annu Rev Ecol Evol S, 40, 677-697, 2009.

Fanton d'Andon, O., Mangin, A., Lavender, S., Antoine, D., Maritorena, S., Morel, A., Barrot, G., Demaria, J., and Pinnock, S.: http://globcolour.info, last access: 8-Dec 2015.

Fautin, D. G. and Buddemeier, R.

W.: http://drysdale.kgs.ku.edu/website/Specimen_Mapper/datadownload.cfm, last access: 20-Jan 2011. 
Earth Syst. Sci. Data Discuss., https://doi.org/10.5194/essd-2018-64

Manuscript under review for journal Earth Syst. Sci. Data

Discussion started: 27 July 2018

(c) Author(s) 2018. CC BY 4.0 License.

Feldman, G. C. and McClain, C. R.: Ocean Color Web, SEAWiFS. Kuring, N., Bailey, S. W., Franz, B. A., Meister, G., Werdell, P. J., Eplee, R. E. (Ed.), October, http://oceancolor.gsfc.nasa.gov/, NASA Goddard Space Flight Center, 2010.

Feldman, G. C. and McClain, C. R.: Ocean Color Web, SeaWIFS Products. Kuring, N., Bailey, S. W., Franz, B. A., Meister, G., Werdell, P. J., Eplee, R. E. (Ed.), July, http://oceancolor.gsfc.nasa.gov/, NASA Goddard Space Flight Center, 2009.

Feldman, G. C. and McClain, C. R.: Ocean Color Web, SeaWIFS Reprocessing 5.1. Kuring, N. and Bailey, S. W. (Eds.), 24 Feb, http://oceancolor.gsfc.nasa.gov/, NASA Goddard Space Flight Center, 2006.

Franklin, J. and Miller, J. A.: Mapping Species Distributions: Spatial Inference and Prediction, Cambridge University Press, New York, 2009.

Gong, G., Mattevada, S., and O'Bryant, S. E.: Comparison of the accuracy of kriging and IDW interpolations in estimating groundwater arsenic concentrations in Texas, Environmental research, 130, 59-69, 2014.

Gordon, H. R., Boynton, G. C., Balch, W. M., Groom, S. B., Harbour, D. S., and Smyth, T. J.: Retrieval of coccolithophore calcite concentration from SeaWiFS Imagery, Geophys Res Lett, 28, 1587-1590, 2001.

Graham, M. H., Kinlan, B. P., Druehl, L. D., Garske, L. E., and Banks, S.: Deep-water kelp refugia as potential hotspots of tropical marine diversity and productivity, P Natl Acad Sci USA, 104, 1657616580, 2007.

Gregg, W. W. and Casey, N. W.: Sampling biases in MODIS and SeaWiFS ocean chlorophyll data, Remote Sensing of Environment, 111, 25-35, 2007.

Guinotte, J. M., Bartley, J. D., Iqbal, A., Fautin, D. G., and Buddemeier, R. W.: Modeling habitat distribution from organism occurrences and environmental data: case study using anemonefishes and their sea anemone hosts, Marine Ecology Progress Series, 316, 269-283, 2006.

Halpern, B. S., Walbridge, S., Selkoe, K. A., Kappel, C. V., Micheli, F., D'Agrosa, C., Bruno, J. F., Casey, K. S., Ebert, C., Fox, H. E., Fujita, R., Heinemann, D., Lenihan, H. S., Madin, E. M. P., Perry, M. T., Selig, E. R., Spalding, M., Steneck, R., and Watson, R.: A global map of human impact on marine ecosystems, Science, 319, 948-952, 2008.

Hartkamp, A. D., De Beurs, K., Stein, A., and White, J. W.: Interpolation techniques for climate variables, CIMMYT, Mexico, DF, 1999.

Hijmans, R. J., Cameron, S. E., Parra, J. L., Jones, P. G., and Jarvis, A.: Very high resolution interpolated climate surfaces for global land areas, International Journal of Climatology, 25, 19651978, 2005.

Hoepffner, N., Sturm, B., Finenko, Z., and Larkin, D.: Depth-integrated primary production in the eastern tropical and subtropical North Atlantic basin from ocean colour imagery, Int J Remote Sens, 20, 1435-1456, 1999.

Hooker, S. B. and McClain, C. R.: The calibration and validation of SeaWiFS data, Progress in Oceanography, 45, 427-465, 2000.

IOC, IHO, and BODC: Centenary edition of the GEBCO digital atlas,published on CD-ROM on behalf of the Intergovernmental Oceanographic Commission and the International Hydrographic 
Earth Syst. Sci. Data Discuss., https://doi.org/10.5194/essd-2018-64

Manuscript under review for journal Earth Syst. Sci. Data

Discussion started: 27 July 2018

(c) Author(s) 2018. CC BY 4.0 License.

474 Organization as part of the General Bathymetric Chart of the Oceans. British Oceanographic Data

475 Centre, Liverpool, UK, 2003.

476 IPCC Climate Change: Working Group II Report "Impacts, Adaptation and Vulnerability",

477 Cambridge University Press, Cambridge, United Kingdom and New York, NY, USA., 976 pp., 2007.

478 Jiménez-Valverde, A., Nakazawa, Y., Lira-Noriega, A., and Peterson, A. T.: Environmental

479 correlation structure and ecological niche model projections, Biodiversity Informatics, 6, 28-35, 2009.

480 Joseph, V. R. and Kang, L.: Regression-Based Inverse Distance Weighting With Applications to

481 Computer Experiments, Technometrics, 53, 254-265, 2011.

Jungclaus, J.: IPCC-AR4 MPI-ECHAM5_T63L31 MPI-OM_GR1.5L40 SRESA1B run no.1: ocean monthly mean values MPImet/MaD Germany. In: World Data Center for Climate. CERA-DB "OMGR1.5L40_EH5-T63L31_A1B_1_MM" http://cera-

485 www.dkrz.de/WDCC/ui/Compact.jsp?acronym=OM-GR1.5L40 EH5-T63L31 A1B 1 MM, Max-

486 Planck-Institut fuer Meteorologie, Hamburg, Germany, 2006.

487 Kaschner, K., Ready, J. S., Agbayani, E., Rius, J., Kesner-Reyes, K., Eastwood, P. D., South, A. B., 488 Kullander, S., Rees, T., Close, C. H., Watson, R., Pauly, D., and Froese, R.: www.aquamaps.org/data, 489 last access: 1 Mar 2011.

490 Kaschner, K., Schneider, B., Garilao, C., Kesner-Reyes, K., Rius-Barlie, J., and Froese,

491 R.: www.aquamaps.org/envdata/main.php, last access: 8 Oct 2013.

Kaschner, K., Watson, R., Trites, A. W., and Pauly, D.: Mapping world-wide distributions of marine mammal species using a relative environmental suitability (RES) model, Mar Ecol-Prog Ser, 316, 285-310, 2006.

Kennedy, J. J.: A review of uncertainty in in situ measurements and data sets of sea surface temperature, Reviews of Geophysics, doi: 10.1002/2013RG000434, 2014. 2013RG000434, 2014.

Longhurst, A., Sathyendranath, S., Platt, T., and Caverhill, C.: An estimate of global primary production in the ocean from satellite radiometer data, J Plankton Res, 17, 1245-1271, 1995.

Lu, G. Y. and Wong, D. W.: An adaptive inverse-distance weighting spatial interpolation technique, Computers \& Geosciences, 34, 1044-1055, 2008.

Maritorena, S., d'Andon, O. H. F., Mangin, A., and Siegel, D. A.: Merged satellite ocean color data products using a bio-optical model: Characteristics, benefits and issues, Remote Sensing of Environment, 114, 1791-1804, 2010.

McGillicuddy, D. J., Anderson, L. A., Doney, S. C., and Maltrud, M. E.: Eddy-driven sources and sinks of nutrients in the upper ocean: Results from a 0.1 degrees resolution model of the North Atlantic, Global Biogeochem Cy, 17, 2003.

Millennium Ecosystem Assessment: Ecosystems and human well-being: biodiversity synthesis, World Resources Institute, Washington, DC., 85 pp., 2005.

Morel, A., Huot, Y., Gentili, B., Werdell, P. J., Hooker, S. B., and Franz, B. A.: Examining the consistency of products derived from various ocean color sensors in open ocean (Case 1) waters in the perspective of a multi-sensor approach, Remote Sensing of Environment, 111, 69-88, 2007.

New, M., Lister, D., Hulme, M., and Makin, I.: A high-resolution data set of surface climate over global land areas, Clim Res, 21, 1-25, 2002. 
NGIA: http://msi.nga.mil/NGAPortal/MSI.portal? nfpb=true\& pageLabel=msi portal page 62\&pub Code=0015, last access: 28-Feb-14 2014.

Paul, A. and Schäfer-Neth, C.: Gridded global LGM SST and salinity reconstruction, IGBP PAGES/World Data Center for Paleoclimatology, Boulder Data Contribution Series. NOAA/NGDC Paleoclimatology Program, Boulder CO, USA, 46, 2003.

Peltier, W.: Time dependent topography through the glacial cycle, IGBP PAGES/World Data CenterA for Paleoclimatology Data Contribution Series \# 93-015. NOAA/NGDC Paleoclimatology Program, Boulder CO, USA., 1993. 1993.

R Core Team: R: A language and environment for statistical computing. Vienna, Austria: R Foundation for Statistical Computing; 2013, Open access available at: http://cran.r-project.org, 2014. 2014.

Ready, J., Kaschner, K., South, A. B., Eastwood, P. D., Rees, T., Rius, J., Agbayani, E., Kullander, S., and Froese, R.: Predicting the distributions of marine organisms at the global scale, Ecol Model, 221, 467-478, 2010.

Redfern, J. V., Ferguson, M. C., Becker, E. A., Hyrenbach, K. D., Good, C., Barlow, J., Kaschner, K., Baumgartner, M. F., Forney, K. A., Ballance, L. T., Fauchald, P., Halpin, P., Hamazaki, T., Pershing, A. J., Qian, S. S., Read, A., Reilly, S. B., Torres, L., and Werner, F.: Techniques for cetacean-habitat modeling, Marine Ecology Progress Series, 310, 271-295, 2006.

Reiss, H., Cunze, S., Konig, K., Neumann, H., and Kroncke, I.: Species distribution modelling of marine benthos: a North Sea case study, Marine Ecology Progress Series, 442, 71-86, 2011.

Rinne, H., Kaskela, A., Downie, A.-L., Tolvanen, H., von Numers, M., and Mattila, J.: Predicting the occurrence of rocky reefs in a heterogeneous archipelago area with limited data, Estuarine, Coastal and Shelf Science, 138, 90-100, 2014.

Robinson, L. M., Elith, J., Hobday, A. J., Pearson, R. G., Kendall, B. E., Possingham, H. P., and Richardson, A. J.: Pushing the limits in marine species distribution modelling: lessons from the land present challenges and opportunities, Global Ecol Biogeogr, 20, 789-802, 2011.

Saeedi, H., Basher, Z., and Costello, M. J.: Modelling present and future global distributions of razor clams (Bivalvia: Solenidae), Helgoland Marine Research, 70, 23, 2016.

Saving, S. C.: Half-degree Ocean Floor Analyzed Annual Means from 2001. In: World Ocean Atlas, v06_1, Kansas Geological Survey, University of Kansas., 2006.

Sbrocco, E. J. and Barber, P. H.: MARSPEC: ocean climate layers for marine spatial ecology, Ecology, 94, 979-979, 2013.

Shepard, D.: A two-dimensional interpolation function for irregularly-spaced data, Proceedings of the 1968 23rd ACM national conference, ACM New York, NY, US, 517-524, 1968.

Stephens, C., Antonov, J. I., Boyer, T. P., Conkright, M. E., Locarnini, R. A., O’Brien, T. D., and Garcia, H. E.: World Ocean Atlas 2001, Volume 1: Temperature. S. Levitus, Ed. (CD-ROM). In: NOAA Atlas NESDIS 49, World Ocean Atlas 2001, U.S. Government Printing Office, Washington D.C., 2002.

Stewart, J. S.: Tidal Energetics: Studies with a Barotropic Model, Ph.D. Thesis, University of Colorado, Boulder, CO., 2000. 
Earth Syst. Sci. Data Discuss., https://doi.org/10.5194/essd-2018-64

Manuscript under review for journal Earth Syst. Sci. Data

Discussion started: 27 July 2018

(c) Author(s) 2018. CC BY 4.0 License.

Stramski, D., Reynolds, R. A., Babin, M., Kaczmarek, S., Lewis, M. R., Röttgers, R., Sciandra, A., Stramska, M., Twardowski, M., and Franz, B.: Relationships between the surface concentration of particulate organic carbon and optical properties in the eastern South Pacific and eastern Atlantic Oceans, Biogeosciences, 5, 171-201, 2008.

Thornton, P. E., Running, S. W., and White, M. A.: Generating surfaces of daily meteorological variables over large regions of complex terrain, J Hydrol, 190, 214-251, 1997.

Tittensor, D. P., Baco, A. R., Brewin, P. E., Clark, M. R., Consalvey, M., Hall-Spencer, J., Rowden, A. A., Schlacher, T., Stocks, K. I., and Rogers, A. D.: Predicting global habitat suitability for stony corals on seamounts, J Biogeogr, 36, 1111-1128, 2009.

Tong, R., Purser, A., Guinan, J., and Unnithan, V.: Modeling the habitat suitability for deep-water gorgonian corals based on terrain variables, Ecological Informatics, 13, 123-132, 2013.

Tyberghein, L., Verbruggen, H., Pauly, K., Troupin, C., Mineur, F., and De Clerck, O.: BioORACLE: a global environmental dataset for marine species distribution modelling, Global Ecol Biogeogr, 21, 272-281, 2012.

Valavanis, V., Pierce, G., Zuur, A., Palialexis, A., Saveliev, A., Katara, I., and Wang, J.: Modelling of essential fish habitat based on remote sensing, spatial analysis and GIS. In: Essential Fish Habitat Mapping in the Mediterranean, Valavanis, V. (Ed.), Developments in Hydrobiology, Springer Netherlands, 2008.

Verbruggen, H., Tyberghein, L., Pauly, K., Vlaeminck, C., Van Nieuwenhuyze, K., Kooistra, W. H. C. F., Leliaert, F., and De Clerck, O.: Macroecology meets macroevolution: evolutionary niche dynamics in the seaweed Halimeda, Global Ecol Biogeogr, 18, 393-405, 2009.

Wiley, E. O., McNyset, K. M., Peterson, A. T., C.R. Robins, a., and Stewart, A. M.: Niche modeling perspective on geographic range predictions in the marine environment using a machine-learning algorithm., Oceanography, 16, 120-127, 2003. 
Earth Syst. Sci. Data Discuss., https://doi.org/10.5194/essd-2018-64

Manuscript under review for journal Earth Syst. Sci. Data

Discussion started: 27 July 2018

(c) Author(s) 2018. CC BY 4.0 License.

579 Table 1. Source and description of data in GMED.

\begin{tabular}{|c|c|c|c|c|c|c|}
\hline Layer & Description & Unit & $\begin{array}{l}\text { Original } \\
\text { Spatial } \\
\text { Resolution } \\
\end{array}$ & $\begin{array}{l}\text { Temporal } \\
\text { Range }\end{array}$ & Derivatives & $\begin{array}{l}\text { Primary } \\
\text { Data } \\
\text { Source } \\
\end{array}$ \\
\hline \multicolumn{7}{|l|}{ Physical } \\
\hline Depth & $\begin{array}{l}\text { Water depth taken from } \\
\text { GEBCO } 08 \text { Digital } \\
\text { Atlas. }\end{array}$ & $\mathrm{m}$ & $\begin{array}{l}30 \text { arc- } \\
\text { second }\end{array}$ & - & Mean & 1 \\
\hline Slope & $\begin{array}{l}\text { Slope derived from } \\
\text { GEBCO } 08 \text { using } \\
\text { ArcGIS Spatial Analyst. }\end{array}$ & degree & $\begin{array}{l}5 \text { arc-min } \\
(9.2 \mathrm{~km})\end{array}$ & - & - & - \\
\hline $\begin{array}{l}\text { Aspect } \\
\text { (EW) }\end{array}$ & $\begin{array}{l}\text { East/West Aspect of } \\
\text { seafloor (sin(aspect in } \\
\text { radians)) }\end{array}$ & radians & $\begin{array}{l}5 \text { arc-min } \\
(9.2 \mathrm{~km})\end{array}$ & - & - & 2,3 \\
\hline Aspect (NS) & $\begin{array}{l}\text { North/South Aspect of } \\
\text { seafloor (cos(aspect in } \\
\text { radians)) }\end{array}$ & radians & $\begin{array}{l}5 \text { arc-min } \\
(9.2 \mathrm{~km})\end{array}$ & - & - & 2,3 \\
\hline $\begin{array}{l}\text { Land } \\
\text { distance }\end{array}$ & $\begin{array}{l}\text { Distance to the nearest } \\
\text { shoreline (water cells } \\
\text { only) calculated using } \\
\text { Euclidean distance } \\
\text { formula in ArcGIS. }\end{array}$ & Kilometers & $\begin{array}{l}5 \text { arc-min } \\
(9.2 \mathrm{~km})\end{array}$ & - & - & 3 \\
\hline $\begin{array}{l}\text { Port } \\
\text { Distance }\end{array}$ & $\begin{array}{l}\text { Distance to nearest } \\
\text { seaport, calculated using } \\
\text { Euclidian distance } \\
\text { formula in ArcGIS. }\end{array}$ & $\begin{array}{r}\text { Euclidean } \\
\text { distance }\end{array}$ & $\begin{array}{l}5 \text { arc-min } \\
(9.2 \mathrm{~km})\end{array}$ & - & - & 4 \\
\hline Ice cover & $\begin{array}{l}\text { Mean annual ice cover in } \\
\text { percent as derived from } \\
\text { the National Snow and } \\
\text { Ice Data Centre. Missing } \\
\text { cell values were } \\
\text { interpolated and values } \\
\text { for the ice shelves in the } \\
\text { Antarctic were set to 1.5. }\end{array}$ & $\%(0-1.0)$ & $0.5^{\circ} \times 0.5^{\circ}$ & $1979-2002$ & $\begin{array}{l}\text { Mean, } \\
\text { Summer, } \\
\text { Winter }\end{array}$ & 5 \\
\hline $\begin{array}{l}\text { Tide } \\
\text { average }\end{array}$ & $\begin{array}{l}\text { Tides, average of } \\
\text { maximum amplitude. } \\
\text { These tide model results } \\
\text { are from a global } 0.25^{\circ} \\
\text { tide model, which } \\
\text { assimilated tide estimates } \\
\text { derived from the } \\
\text { TOPEX/Poseidon } \\
\text { altimeter. }\end{array}$ & $\mathrm{m}$ & $\begin{array}{l}0.25^{\circ} \mathrm{x} \\
0.25^{\circ}\end{array}$ & - & Mean & 6 \\
\hline Wave height & $\begin{array}{l}\text { Height of waves in } \\
\text { scaled discrete classes as } \\
\text { provided by the Original } \\
\text { LOICZ Database, for all } \\
\text { coastal and oceanic cells. }\end{array}$ & $\mathrm{m}$ & $0.5^{\circ} \times 0.5^{\circ}$ & - & Mean & 7 \\
\hline Wind speed & $\begin{array}{l}\text { Yearly variations of the } \\
\text { surface marine } \\
\text { atmosphere over the } \\
\text { global oceans. }\end{array}$ & $\mathrm{m} \cdot \mathrm{s}^{-1}$ & $0.5^{\circ} \times 0.5^{\circ}$ & $1945-1989$ & Mean & 8 \\
\hline $\begin{array}{l}\text { Surface } \\
\text { current }\end{array}$ & $\begin{array}{l}\text { Monthly average of } \\
\text { Zonal velocity } \\
\text { (UVEL), meridional } \\
\text { velocity (VVEL) values } \\
\text { in the ocean surface. }\end{array}$ & $\mathrm{m} \cdot \mathrm{s}^{-1}$ & $\begin{array}{l}0.25^{\circ} \mathrm{x} \\
0.25^{\circ}\end{array}$ & 2009-2010 & Mean & 9 \\
\hline $\begin{array}{l}\text { Euphotic } \\
\text { Layer }\end{array}$ & $\begin{array}{l}\text { Depth of the bottom of } \\
\text { the Euphotic Layer i.e. }\end{array}$ & $\mathrm{m}$ & $\begin{array}{l}2.5 \text { arc- } \\
\min (4 \mathrm{~km})\end{array}$ & $1998-2013$ & Mean & $10,11,12$ \\
\hline
\end{tabular}


Earth Syst. Sci. Data Discuss., https://doi.org/10.5194/essd-2018-64

Manuscript under review for journal Earth Syst. Sci. Data

Discussion started: 27 July 2018

(c) Author(s) 2018. CC BY 4.0 License.

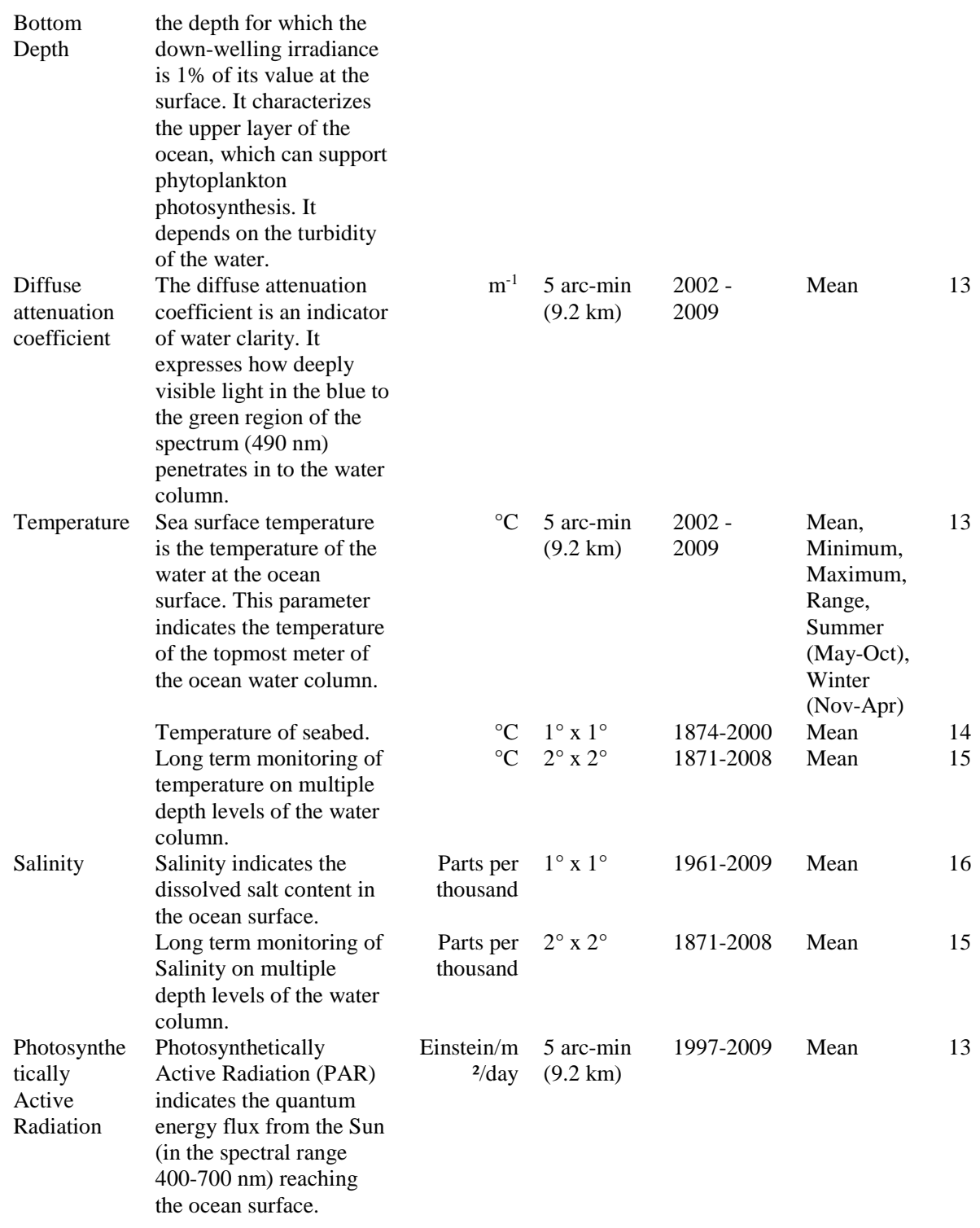


Earth Syst. Sci. Data Discuss., https://doi.org/10.5194/essd-2018-64

Manuscript under review for journal Earth Syst. Sci. Data

Discussion started: 27 July 2018

(c) Author(s) 2018. CC BY 4.0 License.

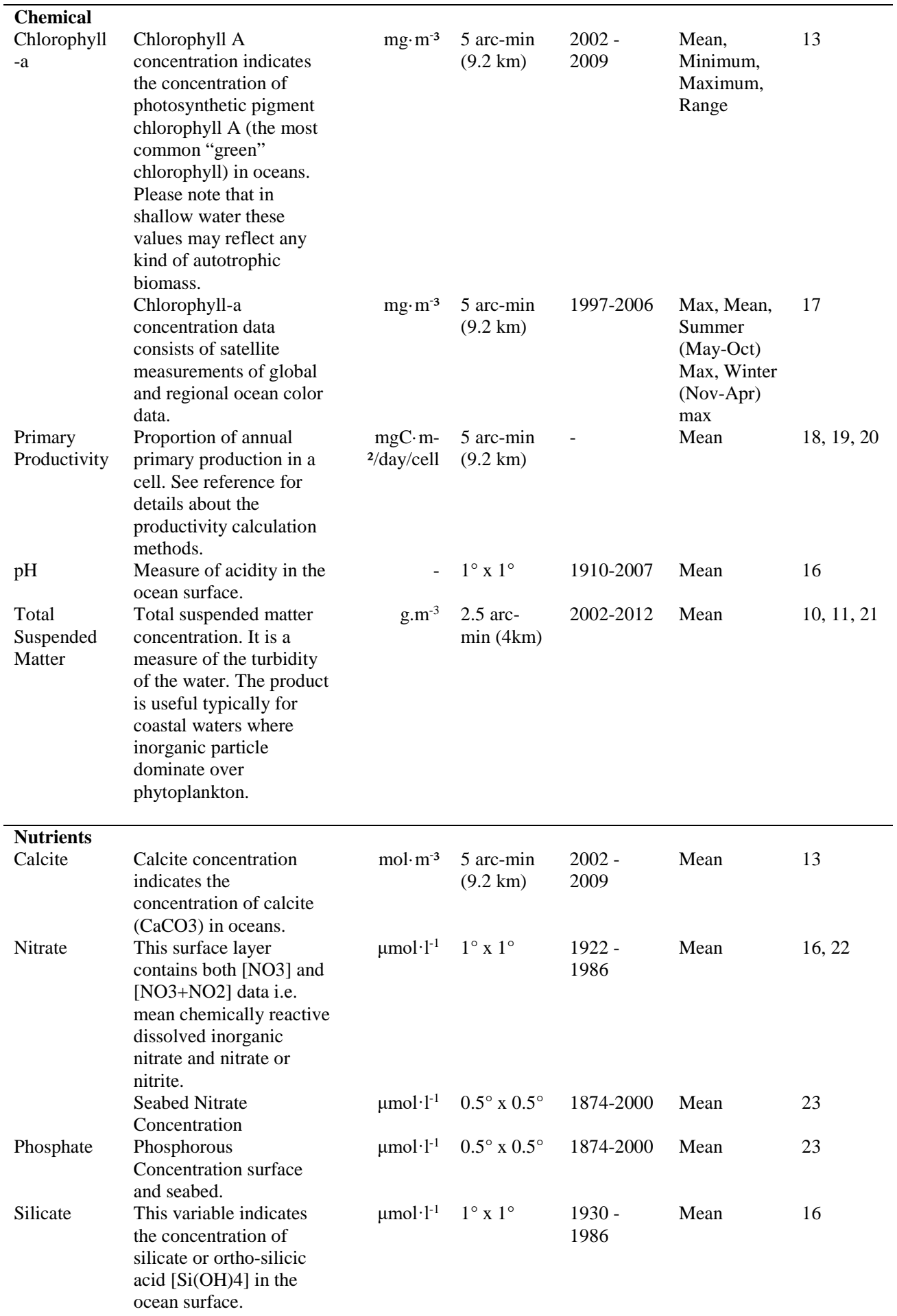


Earth Syst. Sci. Data Discuss., https://doi.org/10.5194/essd-2018-64

Manuscript under review for journal Earth Syst. Sci. Data

Discussion started: 27 July 2018

(c) Author(s) 2018. CC BY 4.0 License.
Seabed Silicate

Concentration.

Dissolved Dissolved oxygen

Oxygen concentration [O2] in the

surface.

Seabed Dissolved

Oxygen Concentration

Saturated

Oxygen

Utilized

Oxygen

POC

PIC
Amount of dissolved

oxygen as a percentage

of maximum potential

oxygen amount that

could be present for the

given temperature and

salinity at standard

atmospheric pressure

(760 $\mathrm{mmHg}$ ) (i.e., sea

level).

Apparent oxygen

utilization (AOU) in $\mathrm{ml} / \mathrm{l}$

- oxygen saturation

concentration minus

measured dissolved

oxygen concentration.

Both for surface and

seabed.

Particulate Organic

Carbon is an important

component in the carbon

cycle and serves as a

primary food sources for aquatic food webs.

Particulate Inorganic

Carbon or suspended

calcium carbonate

concentration

$\begin{array}{cllll}\mu \mathrm{mol} \cdot \mathrm{l}^{-1} & 0.5^{\circ} \times 0.5^{\circ} & 1874-2000 & \text { Mean } & 23 \\ \mathrm{ml} \cdot \mathrm{l}^{-1} & 1^{\circ} \times 1^{\circ} & \begin{array}{l}1898- \\ 2009\end{array} & \text { Mean } & 16 \\ \mathrm{ml} \cdot \mathrm{l}^{-1} & 0.5^{\circ} \times 0.5^{\circ} & 1874-2000 & \text { Mean } & 24 \\ \mathrm{ml} \cdot \mathrm{l}^{-1} & 0.5^{\circ} \times 0.5^{\circ} & 1874-2000 & \text { Mean } & 24\end{array}$

$\mathrm{ml} \cdot \mathrm{l}^{-1} \quad 0.5^{\circ} \times 0.5^{\circ}$

1874-2000 Mean

16

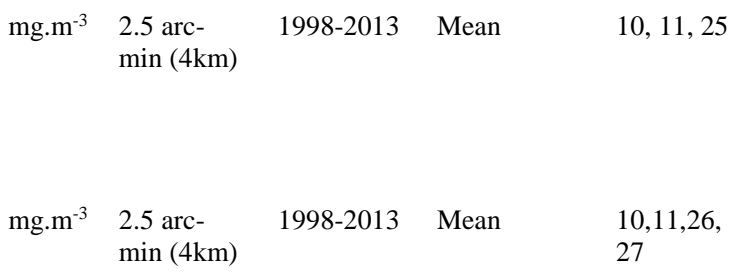

23

16

4

24
Past

Last Glacial Water depth calculated

Maxima

Depth

Last Glacial

Maxima

Temperature

Last Glacial

Maxima

Salinity

Last Glacial

Maxima Ice

Thickness from GEBCO 08 (using

formula current depth$130 \mathrm{~m}$; the average depth decrease mentioned in literature).

Sea surface temperature during last glacial

maxima (22 thousand years ago)

Sea surface salinity

during last glacial

maxima (22 thousand

years ago)

Thickness of ice sheets

during last glacial

maxima (22 thousand

years ago) m 30 arc-

second

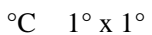

19-22

Mean

cal.KYrBP

Parts per $1^{\circ} \times 1^{\circ}$

19-22

Mean

thousand $\quad$ cal.KYrBP

$\mathrm{km} \quad 1^{\circ} \times 1^{\circ}$

19-22

Mean

cal.KYrBP

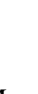

1, 28

Mean

30 
Earth Syst. Sci. Data Discuss., https://doi.org/10.5194/essd-2018-64

Manuscript under review for journal Earth Syst. Sci. Data

Discussion started: 27 July 2018

(c) Author(s) 2018. CC BY 4.0 License.

\begin{tabular}{|c|c|c|c|c|c|c|}
\hline \multicolumn{7}{|l|}{$\begin{array}{l}\text { Future } \\
\end{array}$} \\
\hline \multirow[t]{2}{*}{$\begin{array}{l}\text { Temperature } \\
\text { at } 2100\end{array}$} & $\begin{array}{l}\text { Future grids of monthly } \\
\text { mean sea surface } \\
\text { temperature, A1B ( } 720 \\
\text { ppm stabilization) } \\
\text { scenario. }\end{array}$ & ${ }^{\circ} \mathrm{C}$ & $\begin{array}{l}1.25^{\circ} \mathrm{x} \\
1.25^{\circ}\end{array}$ & 2087-2096 & Mean & 31 \\
\hline & $\begin{array}{l}\text { Predicted seabed } \\
\text { temperature for year } \\
2100 \text {. }\end{array}$ & ${ }^{\circ} \mathrm{C}$ & $0.5^{\circ} \times 0.5^{\circ}$ & 2090-2099 & Mean & 32 \\
\hline \multirow[t]{2}{*}{$\begin{array}{l}\text { Salinity at } \\
2100\end{array}$} & $\begin{array}{l}\text { Future grid of average } \\
\text { monthly mean sea } \\
\text { surface salinity }\end{array}$ & $\begin{array}{l}\text { Parts per } \\
\text { thousand }\end{array}$ & $\begin{array}{l}2.75^{\circ} \mathrm{x} \\
3.75^{\circ}\end{array}$ & 2087-2096 & Mean & 31 \\
\hline & $\begin{array}{l}\text { Predicted seabed salinity } \\
\text { for year } 2100 .\end{array}$ & $\begin{array}{l}\text { Parts per } \\
\text { thousand }\end{array}$ & $0.5^{\circ} \times 0.5^{\circ}$ & 2090-2099 & Mean & 32 \\
\hline $\begin{array}{l}\text { Primary } \\
\text { productivity } \\
\text { at } 2100\end{array}$ & $\begin{array}{l}\text { Predicted primary } \\
\text { productivity for year } \\
2100 .\end{array}$ & $\begin{array}{r}\mathrm{mgC} \cdot \mathrm{m}^{-2} . \mathrm{d} \\
\mathrm{ay}^{-1}\end{array}$ & $0.5^{\circ} \times 0.5^{\circ}$ & 2090-2099 & Mean & 32 \\
\hline $\begin{array}{l}\text { Ice } \\
\text { Concentrati } \\
\text { on at } 2100\end{array}$ & $\begin{array}{l}\text { Predicted ice cover (area } \\
\text { proportion) for year } \\
2100 .\end{array}$ & $\%(0-1)$ & $0.5^{\circ} \times 0.5^{\circ}$ & 2090-2099 & Mean & 32 \\
\hline \multicolumn{7}{|c|}{$\begin{array}{l}\text { 1. (IOC et al., 2003) ; 2.(Becker et al., 2009) ; 3. (Sbrocco and Barber, 2013); 4. (NGIA, 2014); 5. U.S. National } \\
\text { Snow and Ice Data Centre; (Cavalieri et al., 2003); 6. (Stewart, 2000); 7. KGS (Fautin and Buddemeier, 2011); } \\
\text { 8. (Da Silva et al., 1994); 9. NASA JPL Laboratory; 10.(Fanton d'Andon et al., 2009); 11. (Maritorena et al., } \\
\text { 2010); 12. (Morel et al., 2007); 13. (Feldman and McClain, 2010); 14. (Stephens et al., 2002); 15. 20th Century } \\
\text { Reanalysis V2 data provided by the NOAA/OAR/ESRL PSD, Boulder, Colorado, USA; 16. (Boyer et al., 2009) } \\
\text { 17. (Feldman and McClain, 2006); 18.(Bouvet et al., 2002); 19. (Hoepffner et al., 1999); 20. (Longhurst et al., } \\
\text { 1995); 21. (Doerffer and Schiller, 2007); 22. NOAA/NGDC Paleoclimatology Program, Boulder CO, USA. ; } 23 . \\
\text { (Saving, 2006); 24. (Conkright et al., 2002); 25. (Stramski et al., 2008); 26. (Balch et al., 2005); 27. (Gordon et } \\
\text { al., 2001); 28. (Bintanja et al., 2005); 29. (Paul and Schäfer-Neth, 2003); 30. (Peltier, 1993); 31. Based on IPCC } \\
\text { (WCRP CMIP3) multi-model database (http://esg.llnl.gov:8080/index.jsp).UKMO-HadCM3 model. 32. IPSL } \\
\text { model, A2 scenario (http://icmc.ipsl.fr/) }\end{array}$} \\
\hline
\end{tabular}


Earth Syst. Sci. Data Discuss., https://doi.org/10.5194/essd-2018-64

Manuscript under review for journal Earth Syst. Sci. Data

Discussion started: 27 July 2018

(c) Author(s) 2018. CC BY 4.0 License.

594 Table 2. Descriptive statistics for the GMED environmental layers. All values are in annual means

595 and refer the ocean surface unless noted otherwise (see Table 1 for detailed layer descriptions).

596

\begin{tabular}{|c|c|c|c|c|c|c|}
\hline Layers & Minimum & Maximum & Mean & $\begin{array}{r}\text { Std. } \\
\text { Deviation }\end{array}$ & $\begin{array}{l}\text { Std. } \\
\text { Error }\end{array}$ & $\begin{array}{r}\text { Co. } \\
\text { Variation }\end{array}$ \\
\hline \multicolumn{7}{|l|}{ Physical } \\
\hline Depth & -10293.65 & 0.00 & -3440.20 & 1738.53 & 0.72 & -0.51 \\
\hline Slope & 0.00 & 21.65 & 0.98 & 1.22 & 0.00 & 1.24 \\
\hline Aspect (East-West) & -98.94 & 99.94 & -0.03 & 34.27 & 0.01 & -1112.77 \\
\hline Aspect (North-South) & -99.34 & 100.00 & 3.00 & 41.93 & 0.02 & 14.00 \\
\hline Land Distance & 1.00 & 2774.45 & 665.51 & 554.33 & 0.23 & 0.83 \\
\hline Port Distance & 0.00 & 64.16 & 15.63 & 12.36 & 0.01 & 0.79 \\
\hline Ice Cover (Annual) & 0.00 & 1.50 & 0.12 & 0.27 & 0.00 & 2.18 \\
\hline Ice Cover (May-Oct) & 0.00 & 1.50 & 0.12 & 0.28 & 0.00 & 2.29 \\
\hline Ice Cover (Nov-Apr) & 0.00 & 1.50 & 0.11 & 0.28 & 0.00 & 2.56 \\
\hline Wave Height & 0.00 & 7.00 & 0.28 & 0.99 & 0.00 & 3.51 \\
\hline Wind Speed & 0.00 & 12.07 & 7.27 & 1.96 & 0.00 & 0.27 \\
\hline Tide average & 0.00 & 6.40 & 0.46 & 0.45 & 0.00 & 0.97 \\
\hline Current & -0.93 & 1.00 & 0.00 & 0.07 & 0.00 & 16.16 \\
\hline Euphotic Layer Bottom Depth & 7.38 & 142.40 & 72.05 & 23.87 & 0.01 & 0.33 \\
\hline Diffuse Attenuation Coefficient & 0.02 & 0.90 & 0.06 & 0.04 & 0.00 & 0.79 \\
\hline Temperature & -1.00 & 31.54 & 14.40 & 10.94 & 0.00 & 0.76 \\
\hline Temperature Maximum & -1.00 & 35.19 & 16.82 & 11.18 & 0.00 & 0.66 \\
\hline Temperature Minimum & -2.00 & 30.76 & 12.47 & 10.68 & 0.00 & 0.86 \\
\hline Temperature Range & 0.00 & 27.81 & 4.06 & 3.02 & 0.00 & 0.74 \\
\hline Temperature (May-Oct) & -2.10 & 30.72 & 14.44 & 11.33 & 0.00 & 0.78 \\
\hline Temperature (Nov-Apr) & -2.10 & 30.73 & 14.40 & 11.12 & 0.00 & 0.77 \\
\hline Water Column Temperature & -2.30 & 26.03 & 5.55 & 3.63 & 0.00 & 0.65 \\
\hline Seabed Temperature & -2.08 & 29.46 & 1.96 & 3.86 & 0.00 & 1.97 \\
\hline Salinity & 0.00 & 41.00 & 33.60 & 2.50 & 0.00 & 0.07 \\
\hline Water Column Salinity & 6.36 & 40.62 & 34.52 & 1.91 & 0.00 & 0.06 \\
\hline $\begin{array}{l}\text { Photosynthetically Active } \\
\text { Radiation }\end{array}$ & 0.00 & 64.82 & 34.13 & 9.06 & 0.00 & 0.27 \\
\hline \multicolumn{7}{|l|}{ Chemical } \\
\hline Chlorophyll-a & 0.00 & 60.38 & 0.19 & 1.31 & 0.00 & 6.94 \\
\hline Chlorophyll-a Max & 0.00 & 64.00 & 0.47 & 2.23 & 0.00 & 4.75 \\
\hline Chlorophyll-a Min & 0.00 & 57.80 & 0.08 & 0.82 & 0.00 & 10.77 \\
\hline Chlorophyll-a Range & 0.00 & 62.16 & 0.33 & 1.67 & 0.00 & 5.01 \\
\hline $\begin{array}{l}\text { Chlorophyll-a (May-Oct) } \\
\text { Maximum }\end{array}$ & 0.03 & 64.57 & 0.67 & 2.08 & 0.00 & 3.12 \\
\hline $\begin{array}{l}\text { Chlorophyll-a (Nov-Apr) } \\
\text { Maximum }\end{array}$ & 0.02 & 64.57 & 0.42 & 1.31 & 0.00 & 3.16 \\
\hline Primary Productivity & 0.00 & 4875.00 & 370.03 & 277.80 & 0.11 & 0.75 \\
\hline $\mathrm{pH}$ & 6.73 & 8.62 & 8.19 & 0.06 & 0.00 & 0.01 \\
\hline Total Suspended Matter & 0.03 & 48.49 & 0.93 & 2.37 & 0.00 & 2.54 \\
\hline
\end{tabular}


Earth Syst. Sci. Data Discuss., https://doi.org/10.5194/essd-2018-64

Manuscript under review for journal Earth Syst. Sci. Data

Discussion started: 27 July 2018

(c) Author(s) 2018. CC BY 4.0 License.

\begin{tabular}{|c|c|c|c|c|c|c|}
\hline \multicolumn{7}{|l|}{ Nutrient } \\
\hline Calcite & 0.00 & 9.00 & 2.70 & 3.14 & 0.00 & 1.17 \\
\hline Nitrate & 0.00 & 45.96 & 5.23 & 5.91 & 0.00 & 1.13 \\
\hline Seabed Nitrate & 0.00 & 55.78 & 28.58 & 9.85 & 0.00 & 0.34 \\
\hline Phosphate & 0.00 & 2.43 & 0.65 & 0.59 & 0.00 & 0.91 \\
\hline Seabed Phosphate & 0.00 & 4.50 & 2.01 & 0.65 & 0.00 & 0.32 \\
\hline Silicate & 0.00 & 69.00 & 9.59 & 13.26 & 0.01 & 1.38 \\
\hline Seabed Silicate & 0.32 & 267.50 & 98.41 & 52.51 & 0.02 & 0.53 \\
\hline Dissolved $\mathrm{O}_{2}$ & 2.00 & 9.86 & 5.54 & 1.45 & 0.00 & 0.26 \\
\hline Seabed Dissolved $\mathrm{O}_{2}$ & 0.00 & 10.19 & 4.82 & 1.27 & 0.00 & 0.26 \\
\hline Saturated $\mathrm{O}_{2}$ & 76.05 & 113.11 & 100.08 & 3.25 & 0.00 & 0.03 \\
\hline Seabed Utilized $\mathrm{O}_{2}$ & -2.40 & 7.69 & 2.90 & 1.21 & 0.00 & 0.42 \\
\hline Particulate Organic Carbon & 18.49 & 12898.87 & 89.23 & 118.74 & 0.05 & 1.33 \\
\hline Particulate In-organic Carbon & 0.00 & 10808.54 & 142.70 & 212.35 & 0.09 & 1.49 \\
\hline \multicolumn{7}{|l|}{ Past } \\
\hline Depth & -10411.84 & 0.49 & -3836.29 & 1571.24 & 0.68 & -0.41 \\
\hline Temperature & -1.56 & 28.59 & 14.76 & 10.47 & 0.00 & 0.71 \\
\hline Salinity & 4.65 & 41.32 & 35.63 & 1.75 & 0.00 & 0.05 \\
\hline Ice Thickness & 0.00 & 4735.79 & 31.25 & 262.76 & 0.11 & 8.41 \\
\hline \multicolumn{7}{|l|}{ Future } \\
\hline Temperature (A1B Scenario) & -1.61 & 35.05 & 18.04 & 10.91 & 0.00 & 0.60 \\
\hline Temperature (A2 Scenario) & -2.19 & 31.91 & 17.58 & 11.12 & 0.00 & 0.63 \\
\hline Seabed Temp & -2.08 & 31.33 & 2.43 & 4.25 & 0.00 & 1.75 \\
\hline Salinity (A1B Scenario) & 3.37 & 40.05 & 34.37 & 1.99 & 0.00 & 0.06 \\
\hline Salinity (A2 Scenario) & 3.37 & 40.05 & 34.37 & 1.99 & 0.00 & 0.06 \\
\hline Seabed Salinity & 3.38 & 41.07 & 34.60 & 1.44 & 0.00 & 0.04 \\
\hline Primary Productivity & 0.00 & 5004.00 & 354.76 & 277.07 & 0.12 & 0.78 \\
\hline Ice Concentration & 0.00 & 1.50 & 0.05 & 0.16 & 0.00 & 3.16 \\
\hline
\end{tabular}


Earth Syst. Sci. Data Discuss., https://doi.org/10.5194/essd-2018-64

Manuscript under review for journal Earth Syst. Sci. Data

Discussion started: 27 July 2018

(c) Author(s) 2018. CC BY 4.0 License.

Table 3. Comparison of features of freely-available online marine environment datasets. $\sqrt{ }=$ Present,

\begin{tabular}{|c|c|c|c|c|c|c|}
\hline & AQUAMAPS $^{1}$ & $\mathrm{KGS}^{2}$ & HALPERN ${ }^{3}$ & MARSPEC $^{4}$ & $\begin{array}{c}\text { BIO- } \\
\text { ORACLE }^{5}\end{array}$ & GMED \\
\hline $\begin{array}{r}\text { Resolution } \\
\text { arc minute }\end{array}$ & $30^{\prime}$ & $15-30 '$ & $0.5^{\prime}$ & $0.5^{\prime}-10^{\prime}$ & $5^{\prime}$ & $5^{\prime}$ \\
\hline ca. km & 55 & $22-55$ & 1 & $1-20$ & 9 & 9 \\
\hline Uniform file format & $\sqrt{ }$ & $\sqrt{ }$ & $\sqrt{ }$ & $\sqrt{ }$ & $\sqrt{ }$ & $\sqrt{ }$ \\
\hline $\begin{array}{l}\text { Uniform land area } \\
\text { mask }\end{array}$ & $x$ & $\sqrt{ }$ & $x$ & $\sqrt{ }$ & $\sqrt{ }$ & $\sqrt{ }$ \\
\hline $\begin{array}{l}\text { GIS-ready Format } \\
\text { (ASCII Grid or Raster) }\end{array}$ & $x$ & $x$ & $\sqrt{ }$ & $\sqrt{ }$ & $\sqrt{ }$ & $\sqrt{ }$ \\
\hline $\begin{array}{l}\text { Common geographic } \\
\text { extent }\end{array}$ & $\sqrt{ }$ & $x$ & $x$ & $\sqrt{ }$ & $\sqrt{ }$ & $\sqrt{ }$ \\
\hline $\begin{array}{l}\text { Suitable for coastal } \\
\text { studies }\end{array}$ & $x$ & $x$ & $\sqrt{ }$ & $\sqrt{ }$ & $\sqrt{ }$ & $\sqrt{ }$ \\
\hline $\begin{array}{l}\text { High Resolution } \\
\text { Land Mask }\end{array}$ & $x$ & $x$ & $x$ & $\sqrt{ }$ & $x$ & $\sqrt{ }$ \\
\hline Bathymetry & $\sqrt{ }$ & $\sqrt{ }$ & $x$ & $\sqrt{ }$ & $x$ & $\sqrt{ }$ \\
\hline Deep-Sea datasets & $\sqrt{ }$ & $\sqrt{ }$ & $x$ & $x$ & $x$ & $\sqrt{ }$ \\
\hline $\begin{array}{l}\text { Equal-area grids } \\
\text { available }\end{array}$ & $x$ & $x$ & $x$ & $x$ & $\sqrt{ }$ & $\sqrt{ }$ \\
\hline $\begin{array}{l}\text { Future climate } \\
\text { scenario }\end{array}$ & $\sqrt{ }$ & $x$ & $x$ & $x$ & $\sqrt{ }$ & $\sqrt{ }$ \\
\hline $\begin{array}{l}\text { Past climate } \\
\text { condition }\end{array}$ & $x$ & $x$ & $x$ & $\sqrt{ }$ & $x$ & $\sqrt{ }$ \\
\hline $\begin{array}{l}\text { Descriptive statistics } \\
\text { of dataset }\end{array}$ & $x$ & $x$ & $x$ & $x$ & $x$ & $\sqrt{ }$ \\
\hline $\begin{array}{l}\text { Individual dataset } \\
\text { download option }\end{array}$ & $x$ & $x$ & $x$ & $x$ & $x$ & $\sqrt{ }$ \\
\hline
\end{tabular}

${ }^{1}$ AquaMaps (Kaschner et al., 2008), ${ }^{2}$ KGS Hexacoral Project (Fautin and Buddemeier, 2011), ${ }^{3}$ Global Map of Human Impact on Marine Ecosystems (Halpern et al., 2008), ${ }^{4}$ MARSPEC Ocean Climate Layers for Marine Spatial Ecology (Sbrocco et al., 2013), ${ }^{5}$ Bio-Oracle Marine SDM Raster (Tyberghein et al., 2012) 
Earth Syst. Sci. Data Discuss., https://doi.org/10.5194/essd-2018-64

Manuscript under review for journal Earth Syst. Sci. Data

Discussion started: 27 July 2018

(c) Author(s) 2018. CC BY 4.0 License.

(c) (i)

606

Figure 1. Data processing steps used to produce GMED.

611

612
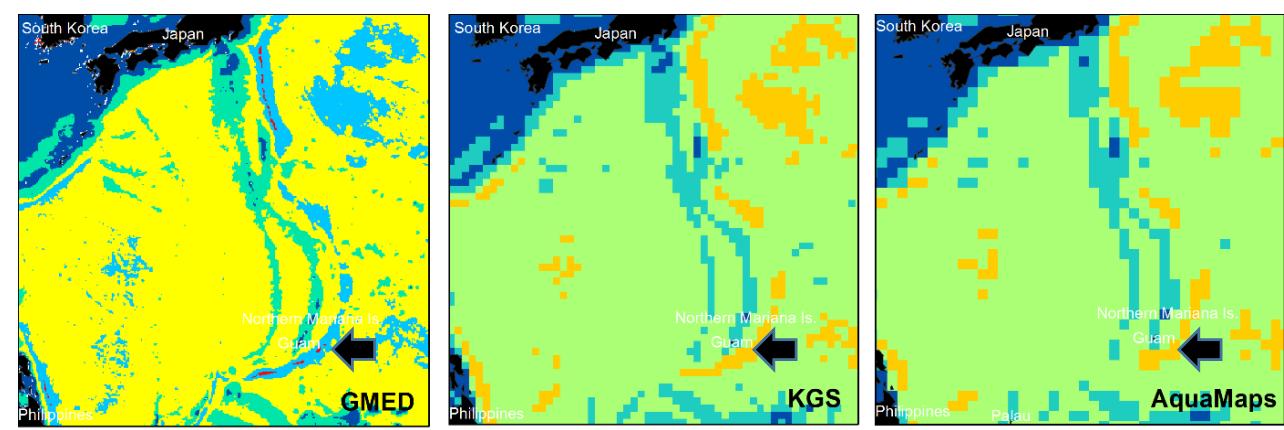

Figure 2. Comparison of Depth layers in GMED (left), KGS Mapper (middle) and AquaMaps (right). The Mariana Trench near the east coast of Japan is more visible (black arrow) in GMED but barely visible in both KGS Mapper and AquaMaps dataset. 
Earth Syst. Sci. Data Discuss., https://doi.org/10.5194/essd-2018-64

Manuscript under review for journal Earth Syst. Sci. Data

Discussion started: 27 July 2018

(c) Author(s) 2018. CC BY 4.0 License.
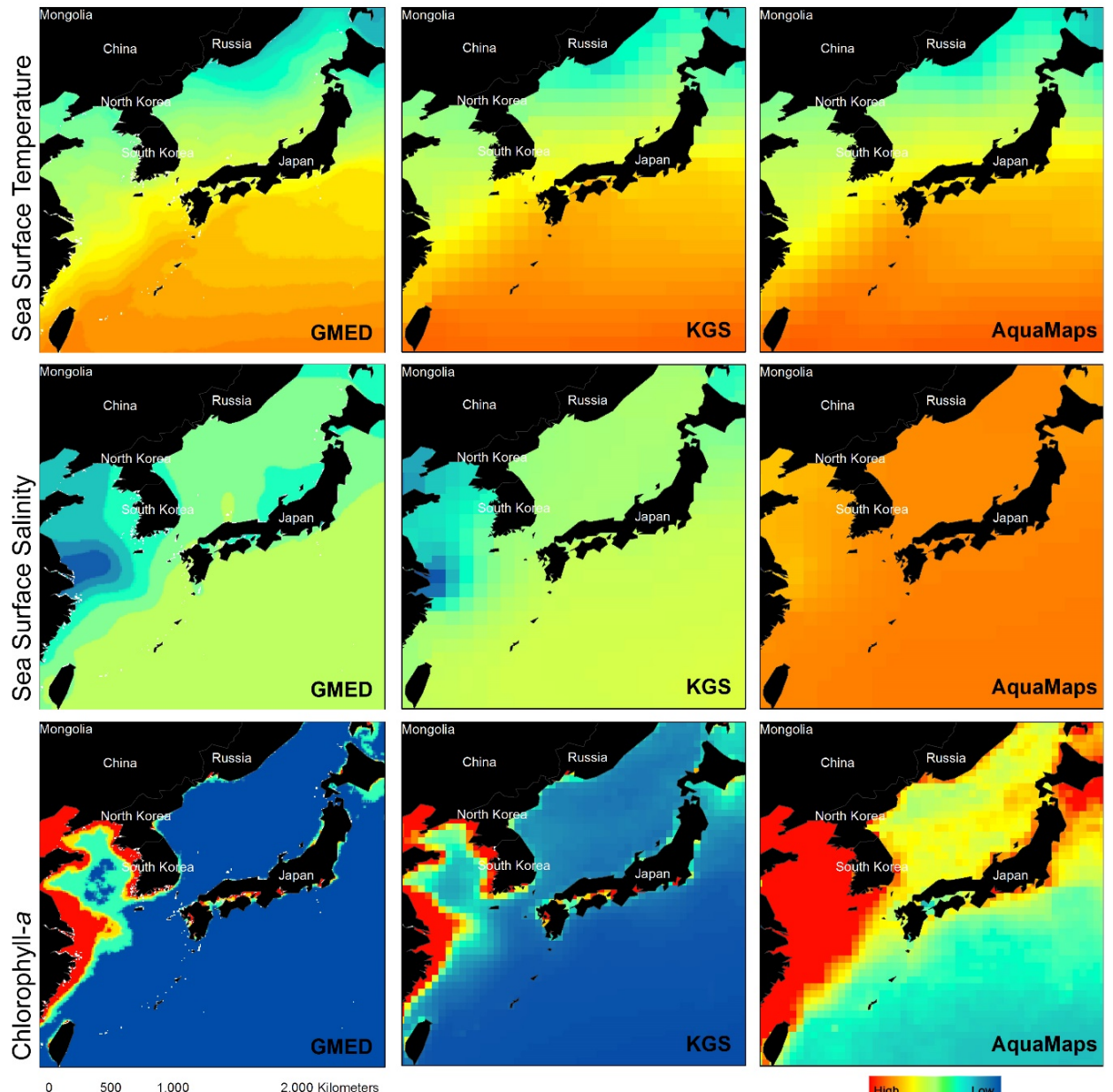

Hith Low

Figure 3. Comparison of mean surface temperature, salinity and chlorophyll-a of GMED with the KGS Mapper and AquaMaps dataset. Data range high (red) to low (blue). 
Earth Syst. Sci. Data Discuss., https://doi.org/10.5194/essd-2018-64

Manuscript under review for journal Earth Syst. Sci. Data

Discussion started: 27 July 2018

(c) Author(s) 2018. CC BY 4.0 License.

(c) (1)

\section{Appendix A: Visualization of GMED Data Layers}

\section{Physical}

Figure A1. Depth

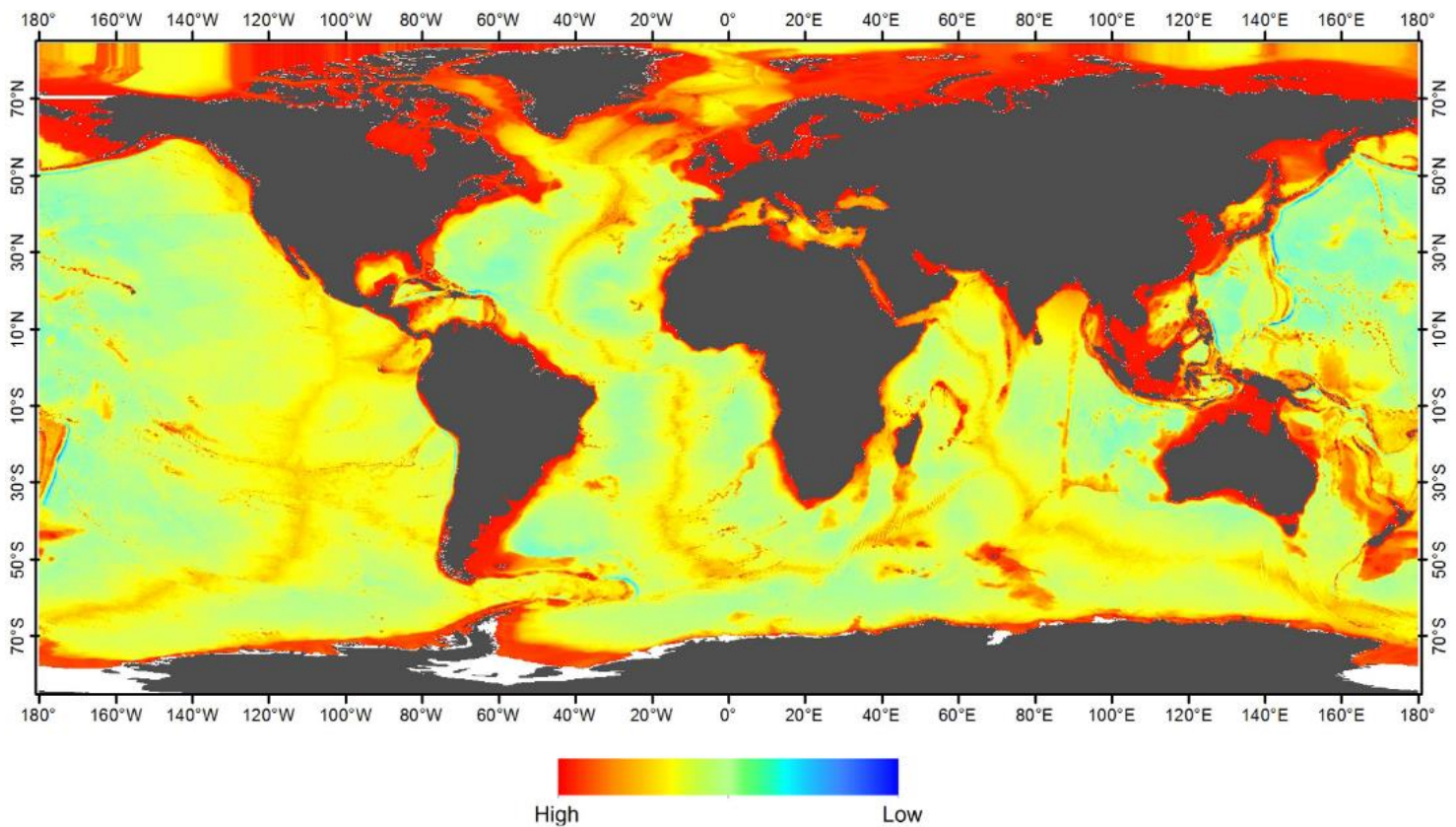

Figure A2. Slope

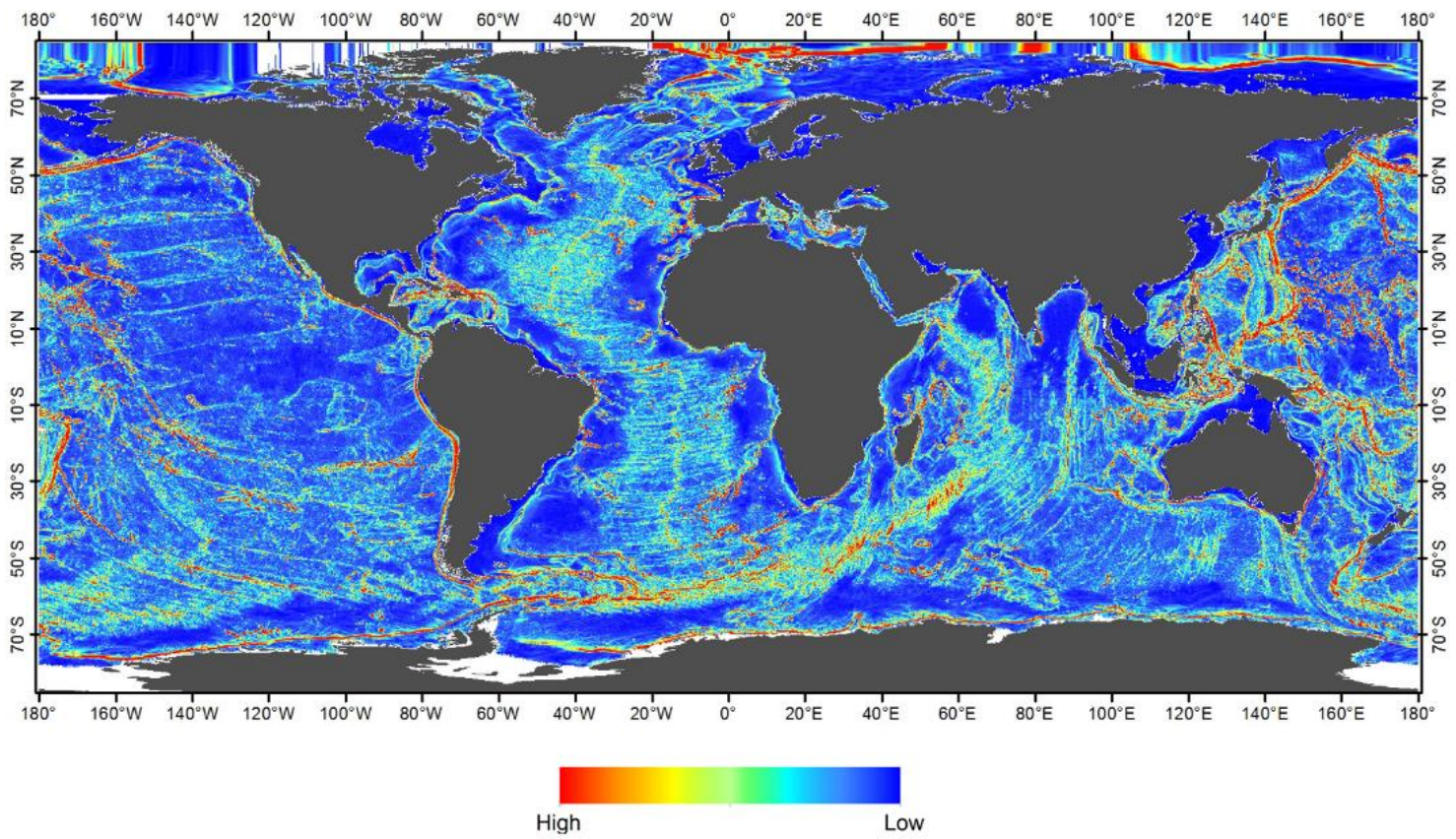


Earth Syst. Sci. Data Discuss., https://doi.org/10.5194/essd-2018-64

Manuscript under review for journal Earth Syst. Sci. Data

Discussion started: 27 July 2018

(c) Author(s) 2018. CC BY 4.0 License.

Figure A3. Aspect (East-West)

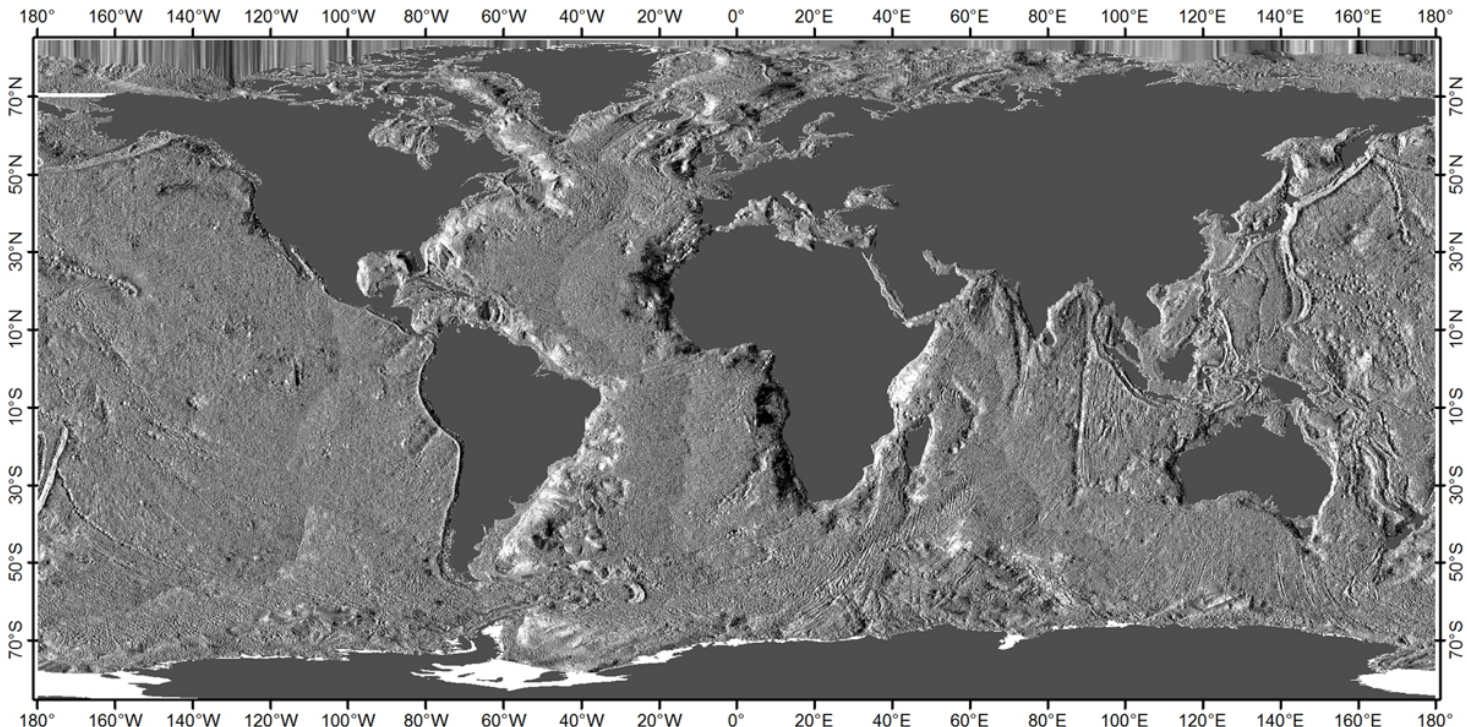

High

Figure A4. Aspect (North-South)

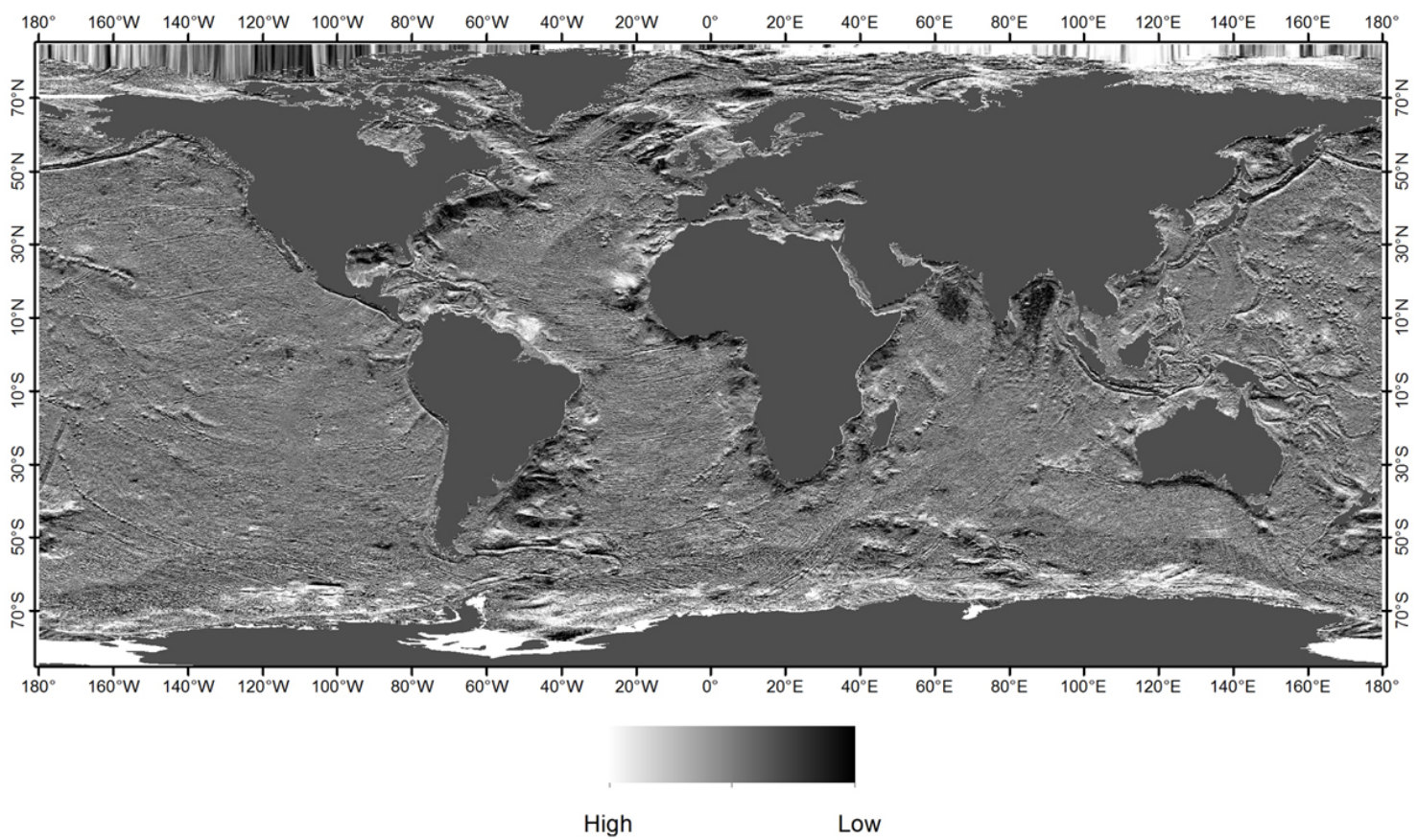


Earth Syst. Sci. Data Discuss., https://doi.org/10.5194/essd-2018-64

Manuscript under review for journal Earth Syst. Sci. Data

Discussion started: 27 July 2018

(c) Author(s) 2018. CC BY 4.0 License.

(c) (i)

Figure A5. Land Distance

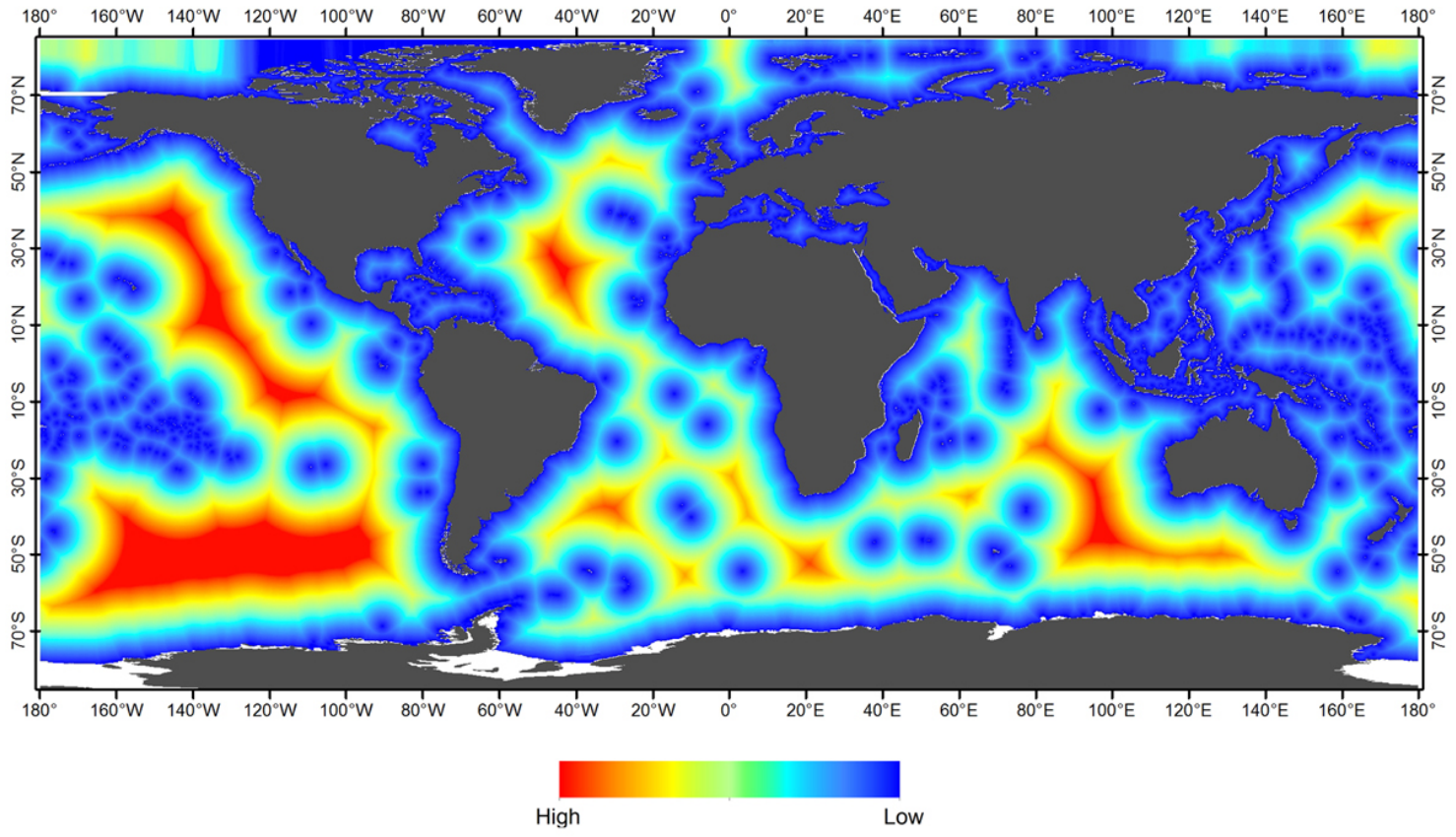

Figure A6. Port Distance 
Earth Syst. Sci. Data Discuss., https://doi.org/10.5194/essd-2018-64

Manuscript under review for journal Earth Syst. Sci. Data

Discussion started: 27 July 2018

(c) Author(s) 2018. CC BY 4.0 License.

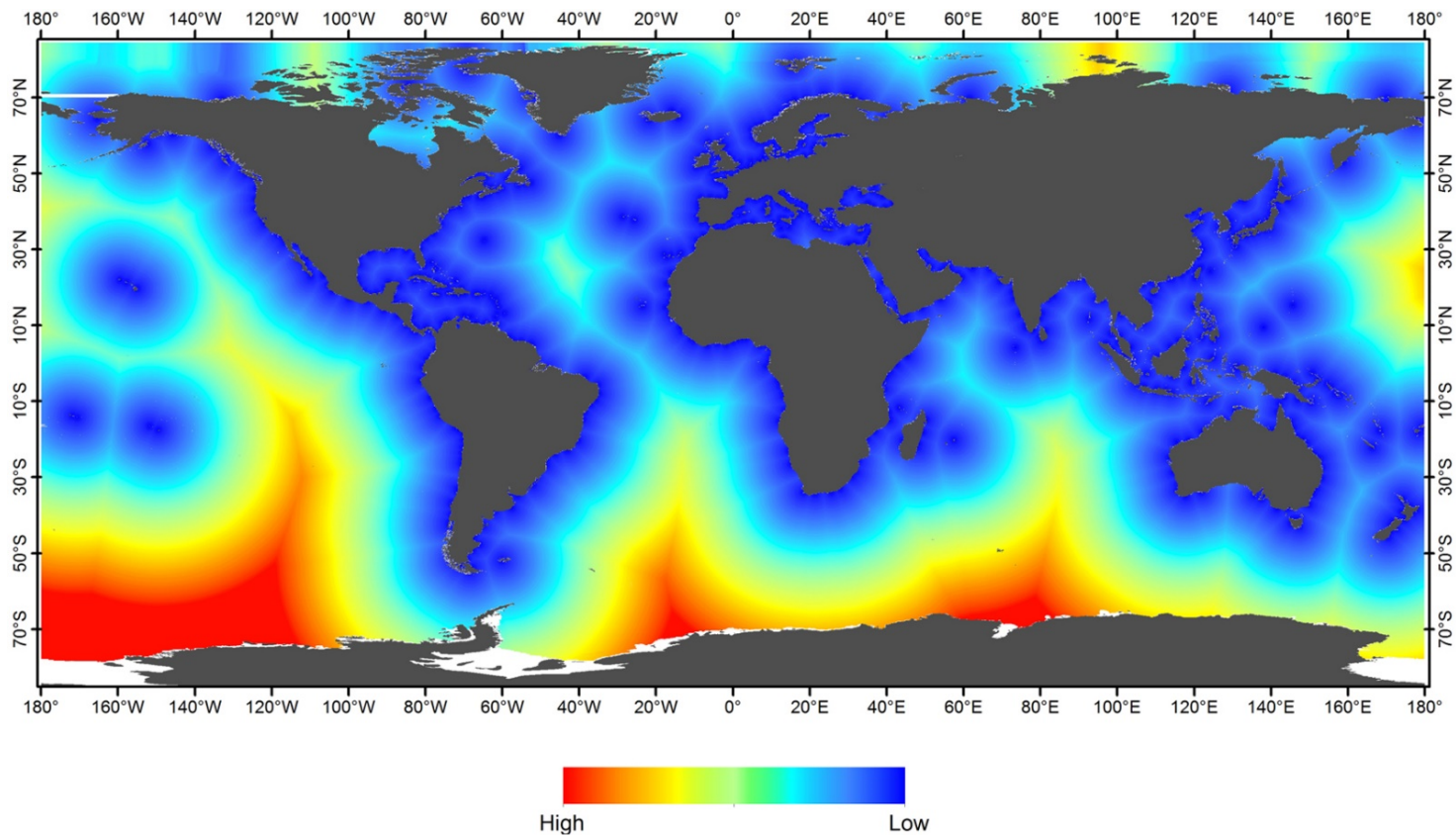

Figure A7. Ice cover (Annual Mean)

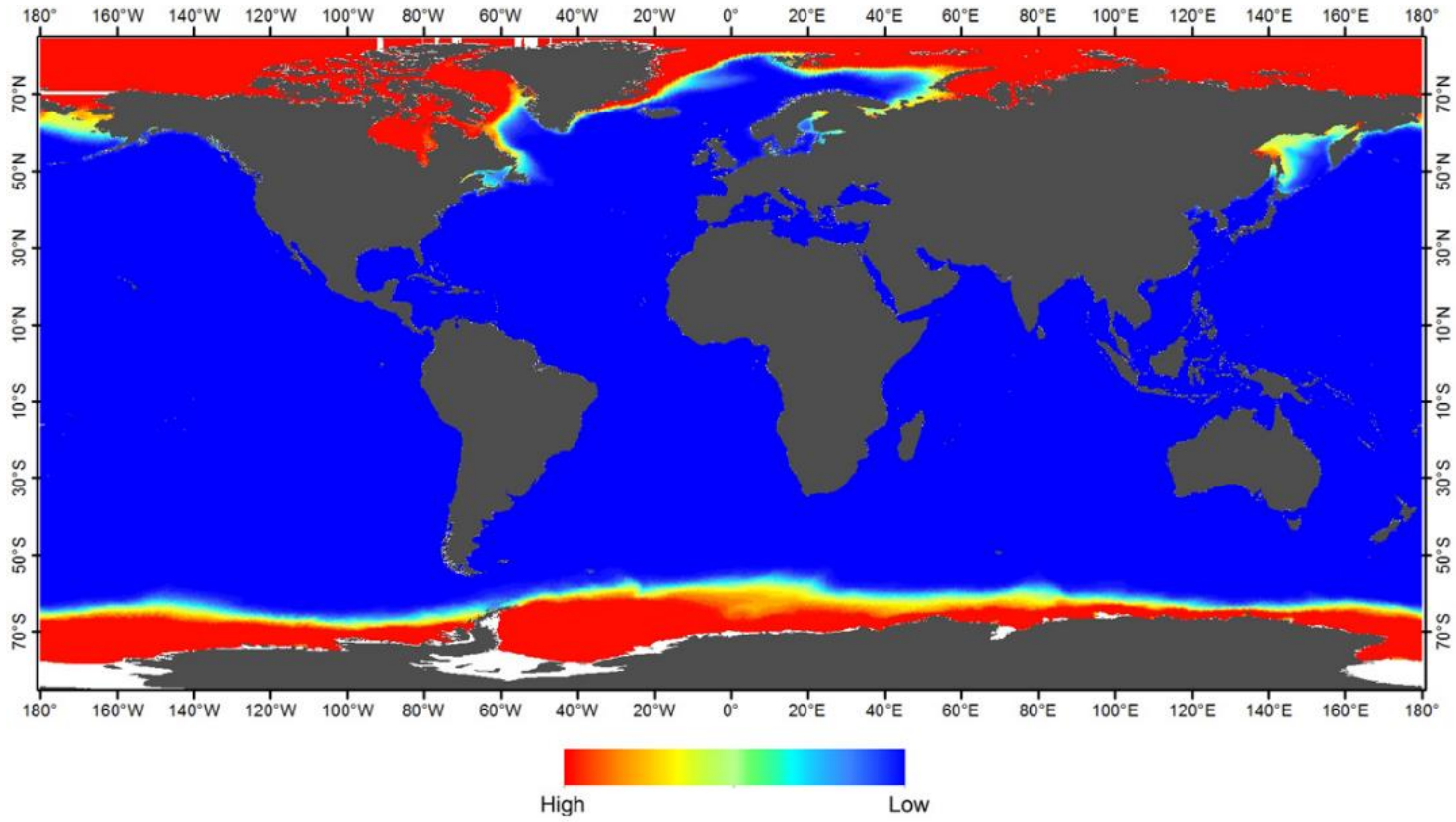

Figure A8. Ice Cover(May-Oct) 
Earth Syst. Sci. Data Discuss., https://doi.org/10.5194/essd-2018-64

Manuscript under review for journal Earth Syst. Sci. Data

Discussion started: 27 July 2018

(c) Author(s) 2018. CC BY 4.0 License.

(c) (i)

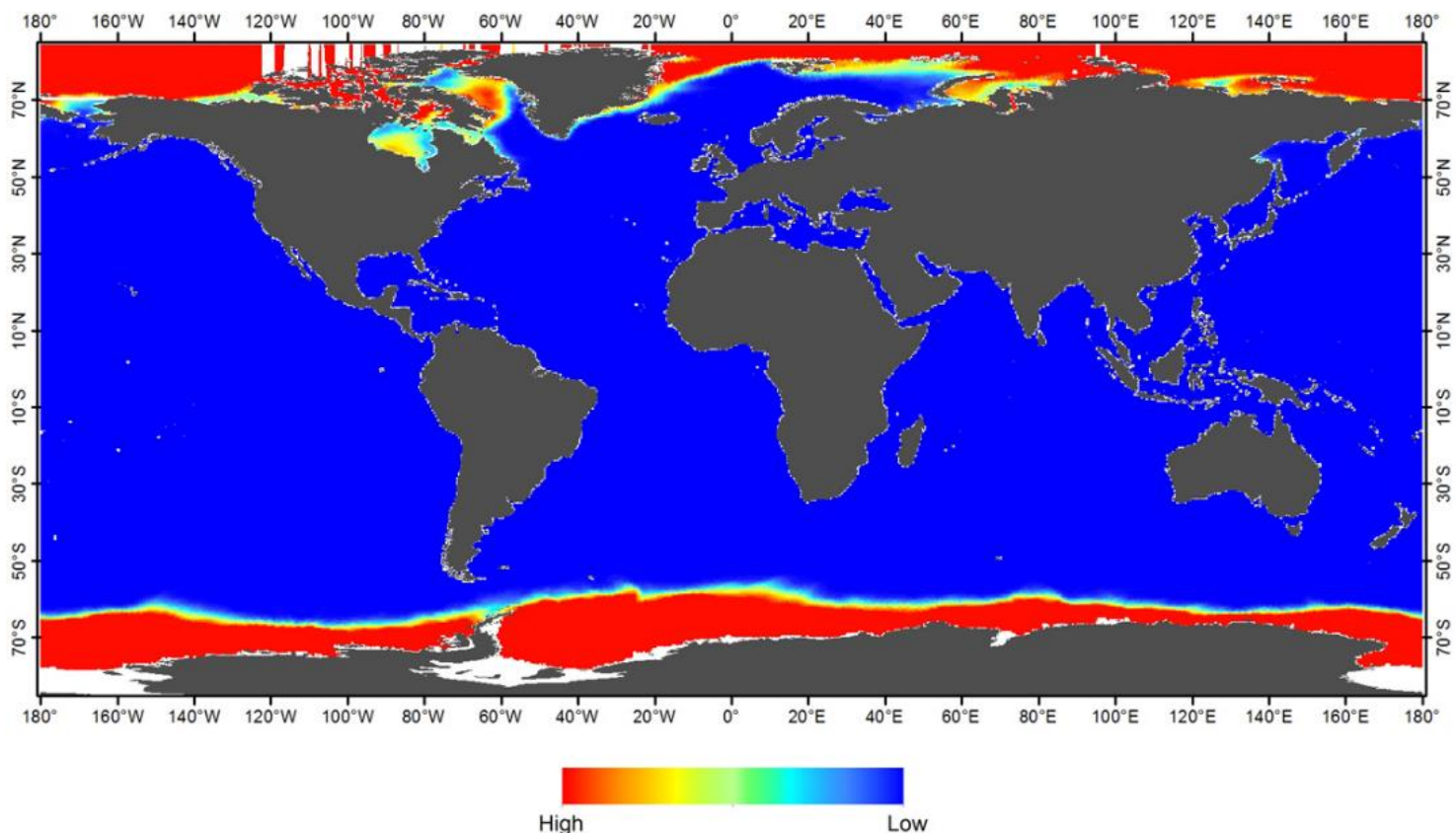


Earth Syst. Sci. Data Discuss., https://doi.org/10.5194/essd-2018-64

Manuscript under review for journal Earth Syst. Sci. Data

Discussion started: 27 July 2018

(c) Author(s) 2018. CC BY 4.0 License.

(c) (i)

Figure A9. Ice Cover (Nov- Apr)

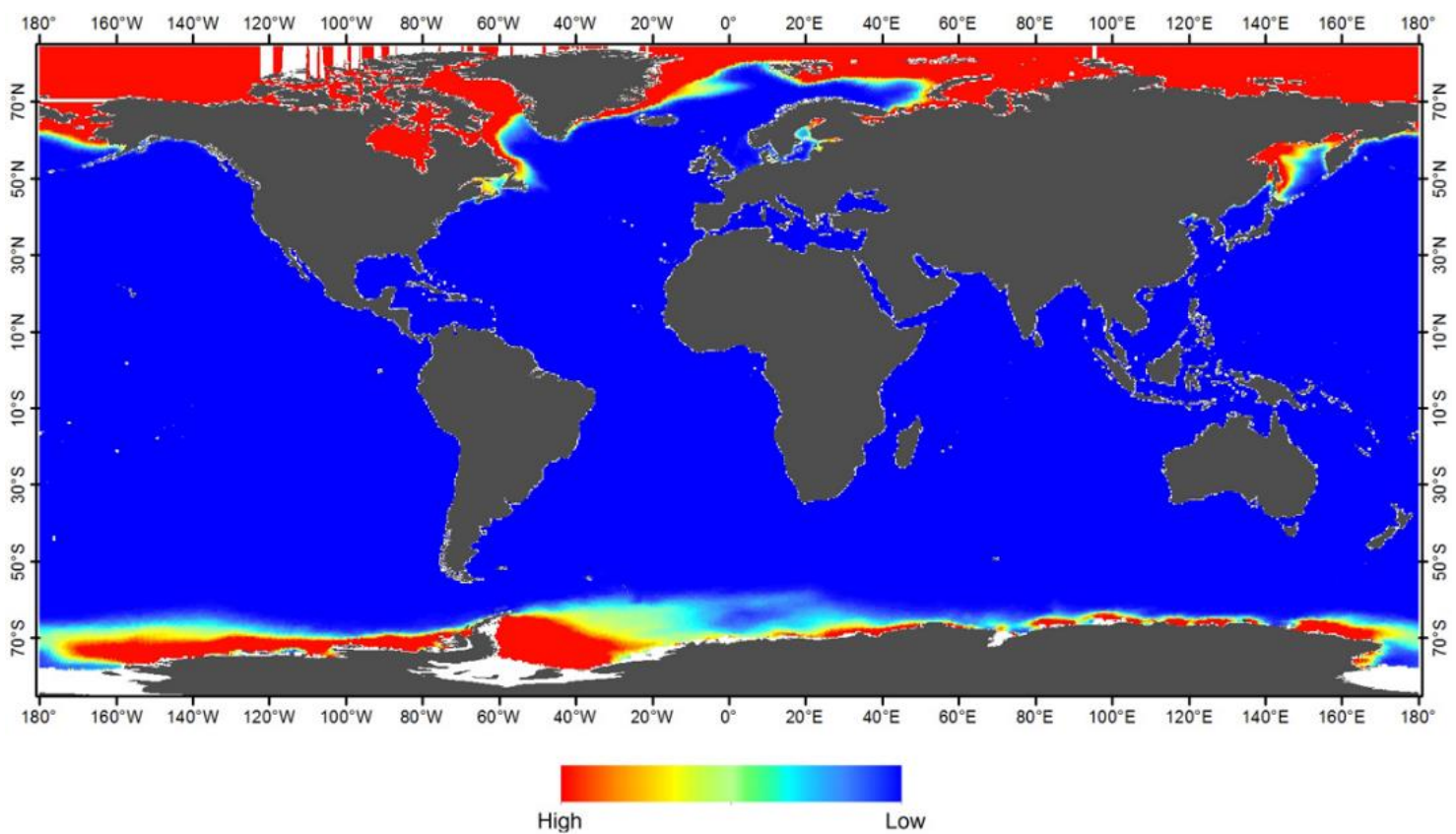

Figure A10. Wave Height

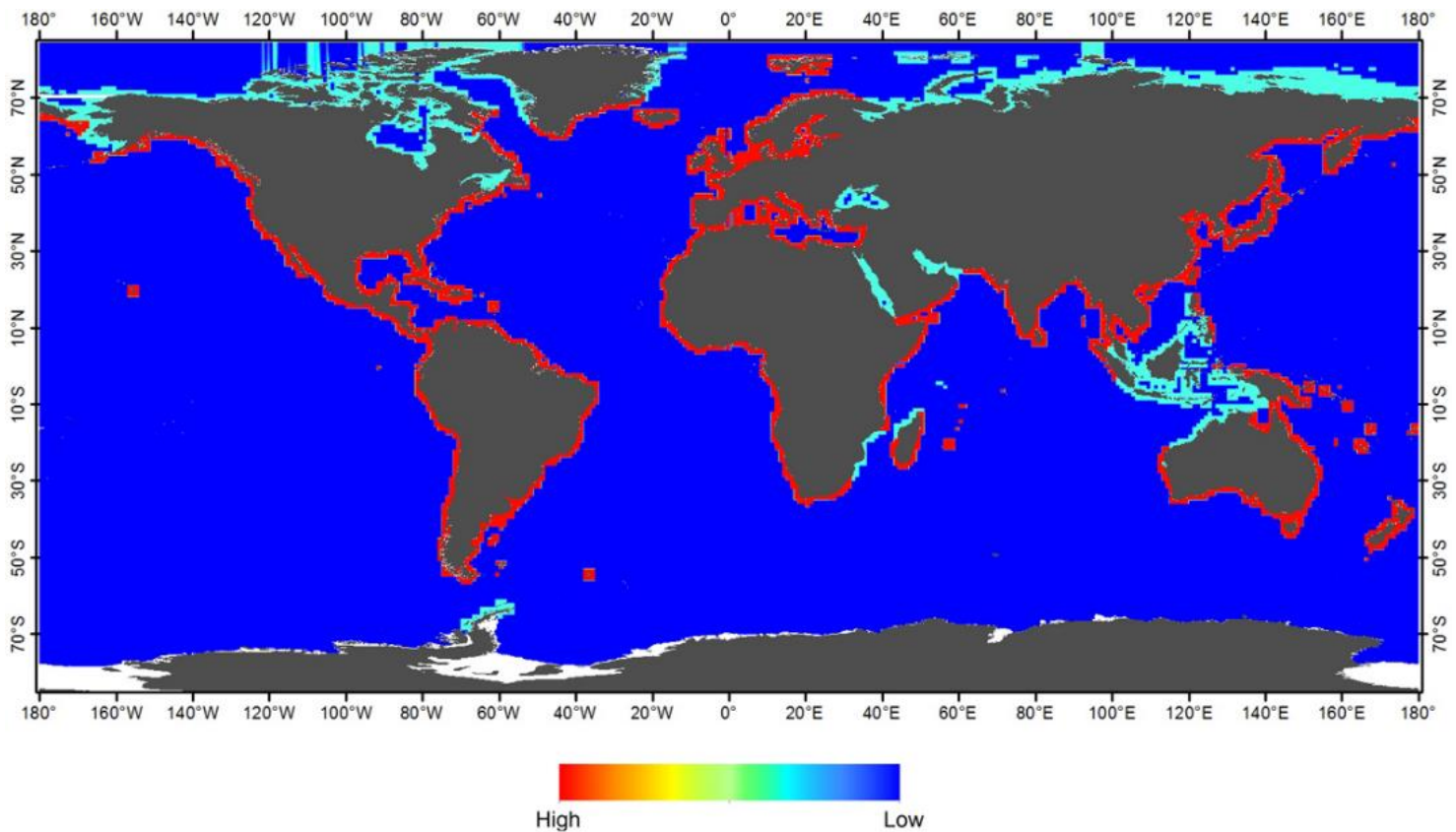


Earth Syst. Sci. Data Discuss., https://doi.org/10.5194/essd-2018-64

Manuscript under review for journal Earth Syst. Sci. Data

Discussion started: 27 July 2018

(c) Author(s) 2018. CC BY 4.0 License.

(c) (i)

Figure A11. Wind Speed

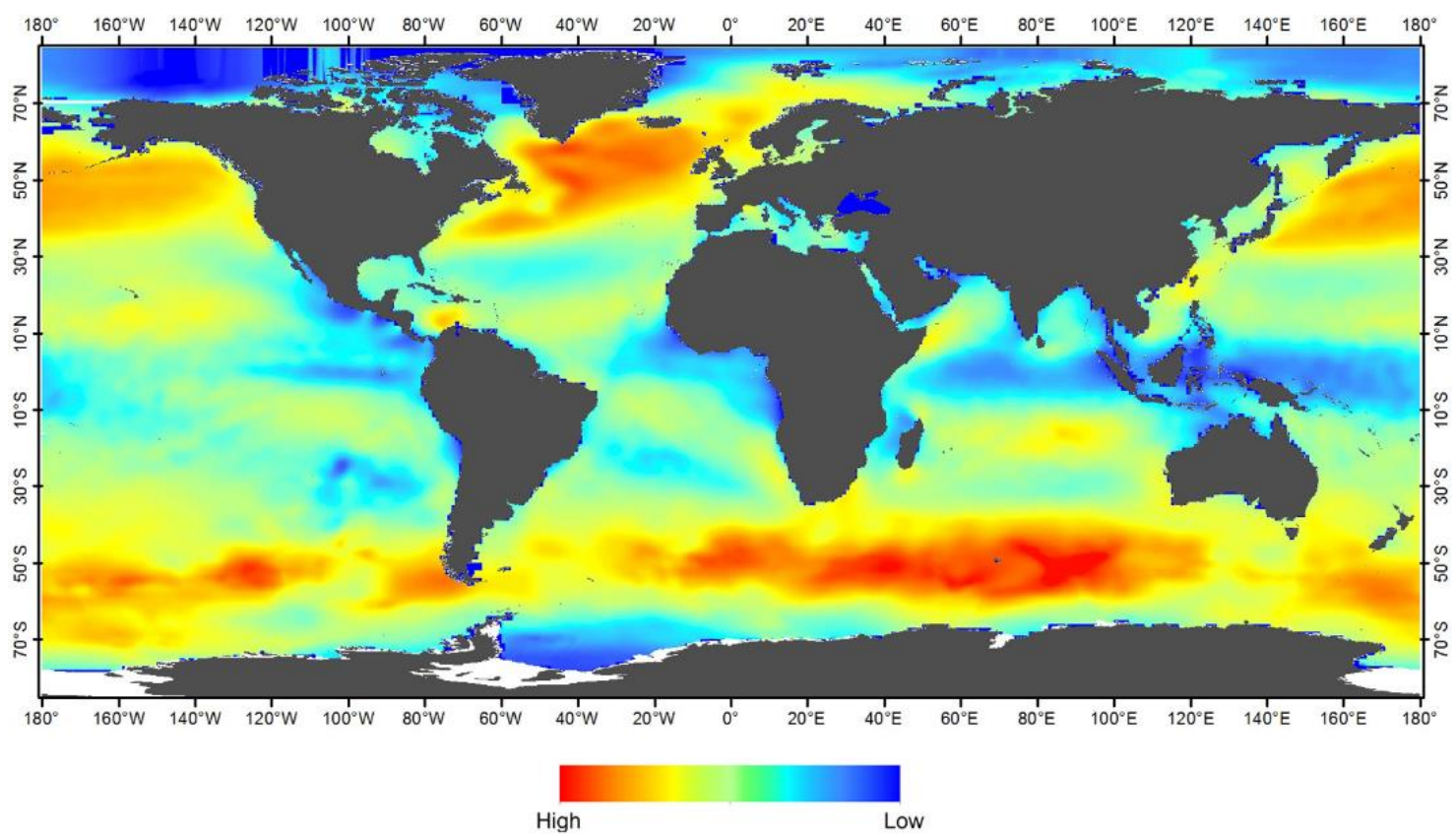

Figure A12. Tide average

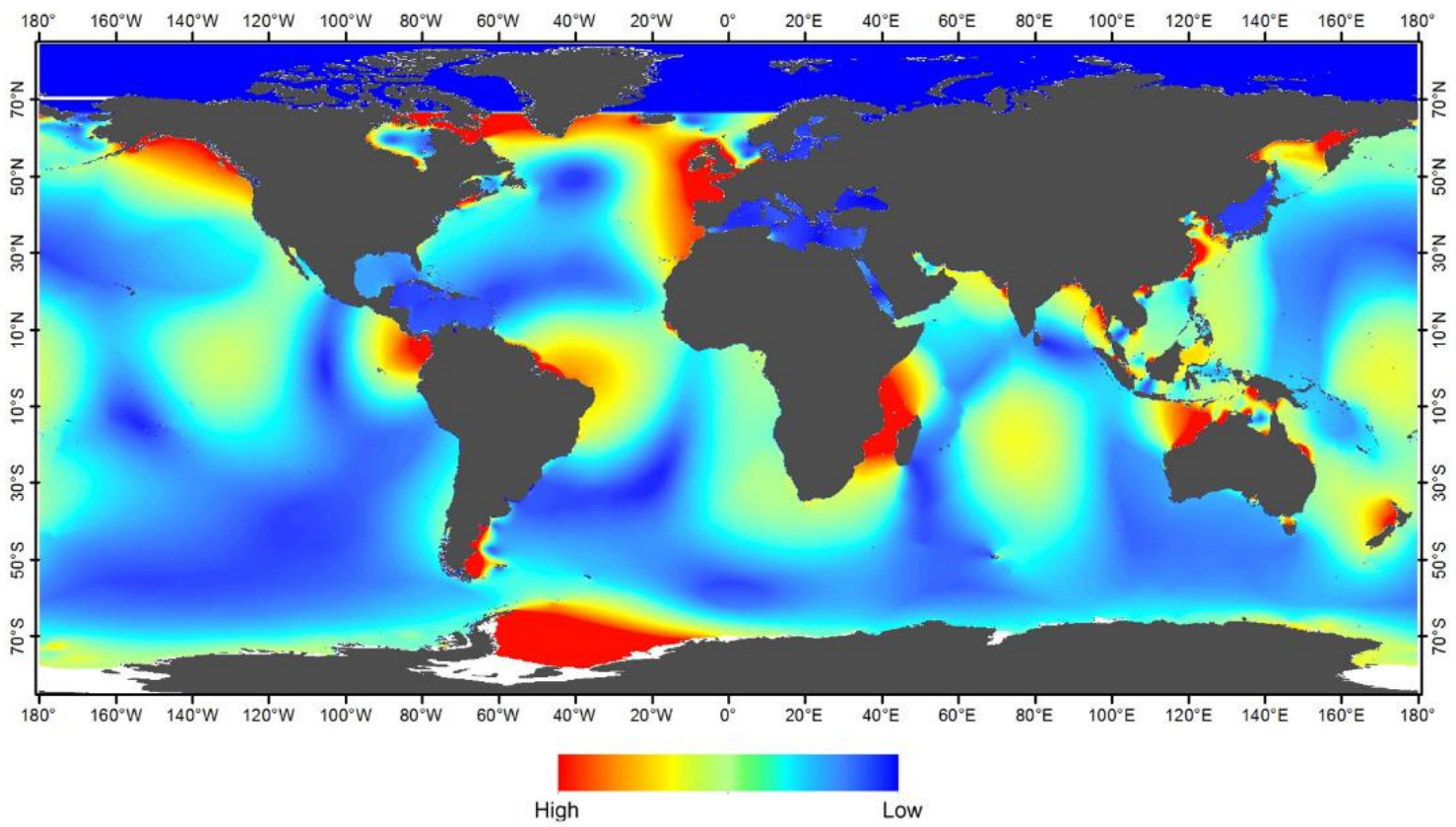


Earth Syst. Sci. Data Discuss., https://doi.org/10.5194/essd-2018-64

Manuscript under review for journal Earth Syst. Sci. Data

Discussion started: 27 July 2018

(c) Author(s) 2018. CC BY 4.0 License.

Figure A13. Surface Current

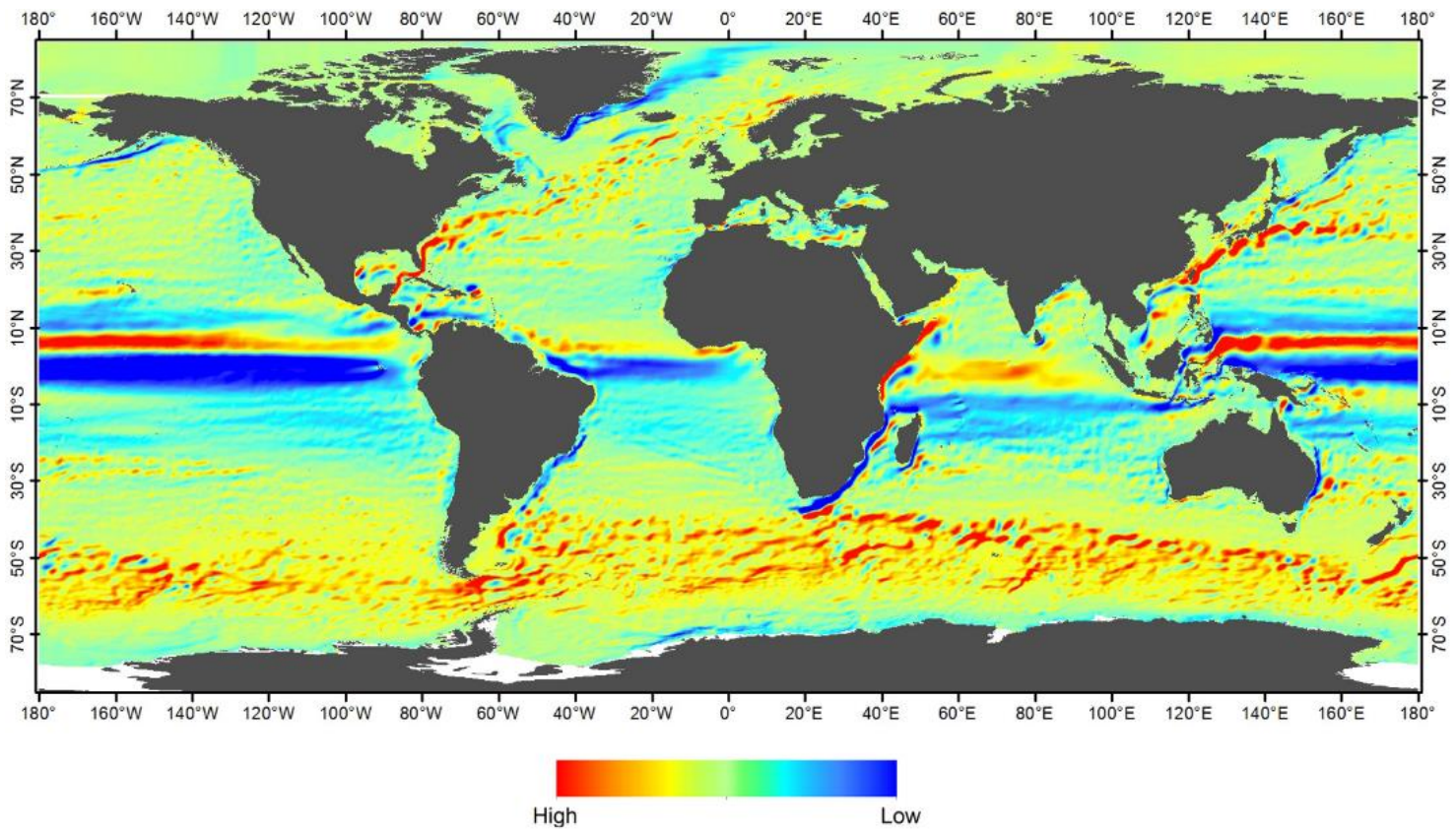

Figure A14. Euphotic Layer Bottom Depth

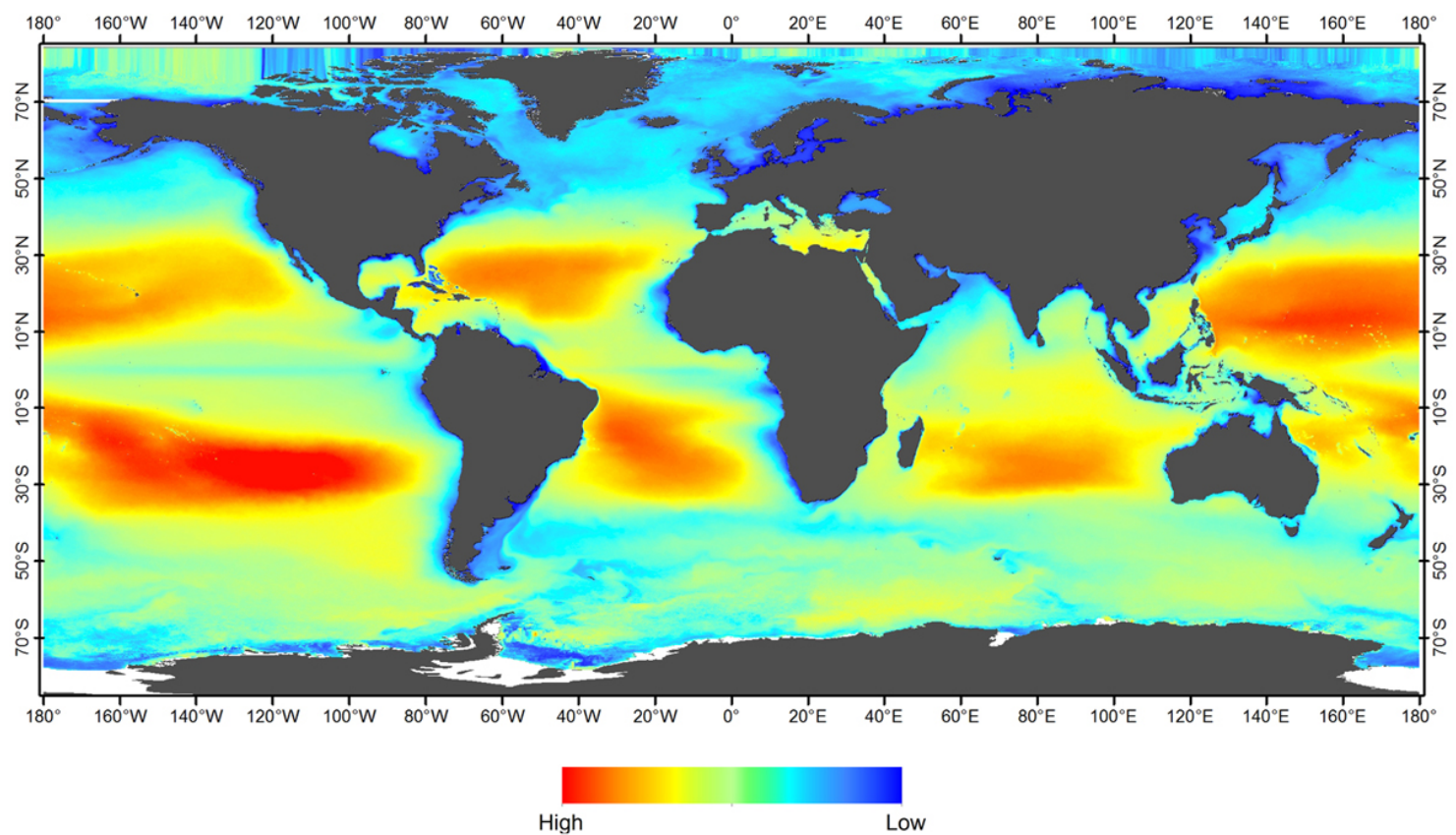


Earth Syst. Sci. Data Discuss., https://doi.org/10.5194/essd-2018-64

Manuscript under review for journal Earth Syst. Sci. Data

Discussion started: 27 July 2018

(c) Author(s) 2018. CC BY 4.0 License.

(c) (i)

Figure A15. Diffuse Attenuation Coefficient

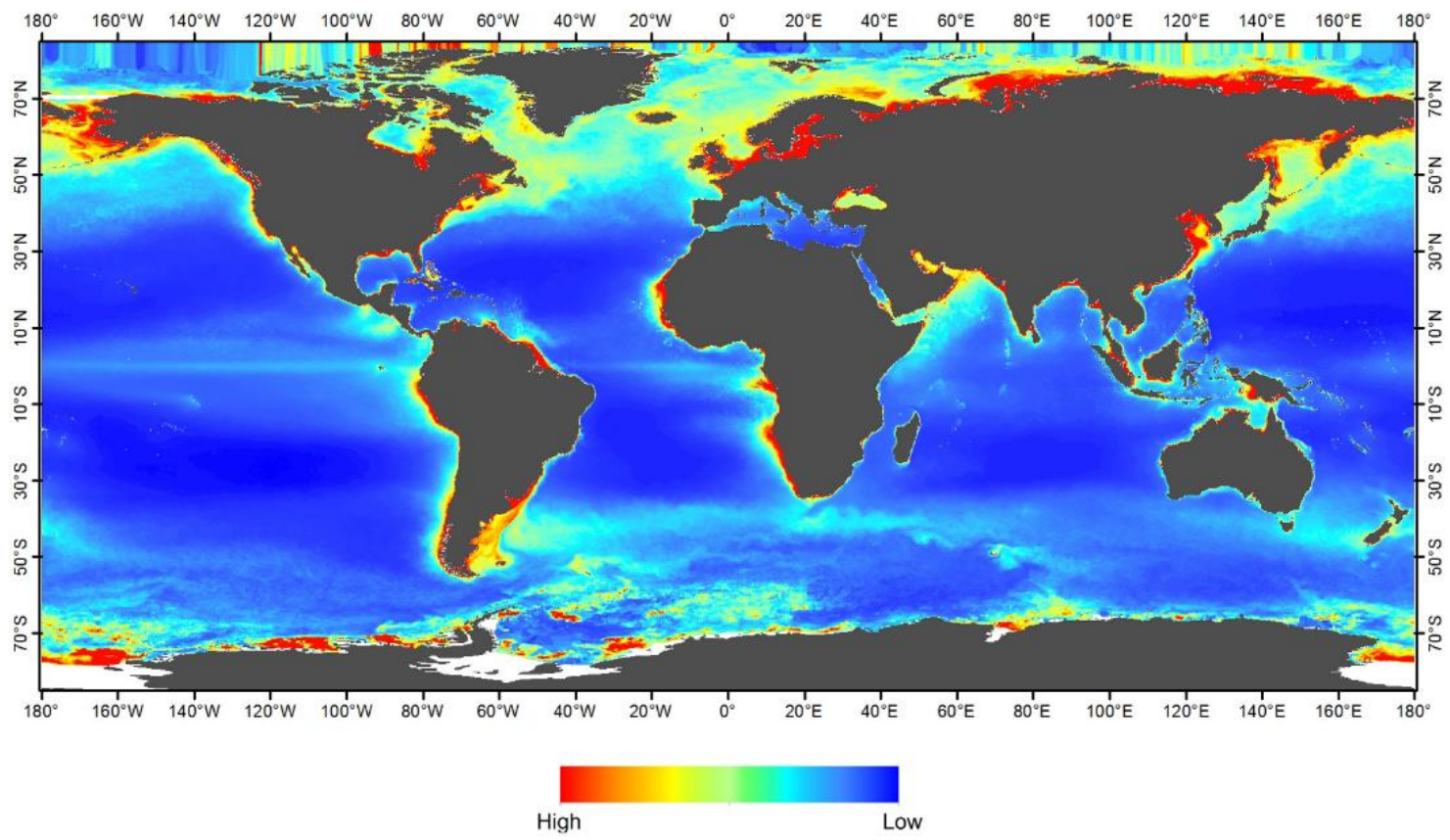

Figure A16. Sea Surface Temperature Mean 
Earth Syst. Sci. Data Discuss., https://doi.org/10.5194/essd-2018-64

Manuscript under review for journal Earth Syst. Sci. Data

Discussion started: 27 July 2018

(c) Author(s) 2018. CC BY 4.0 License.

(c) (1)

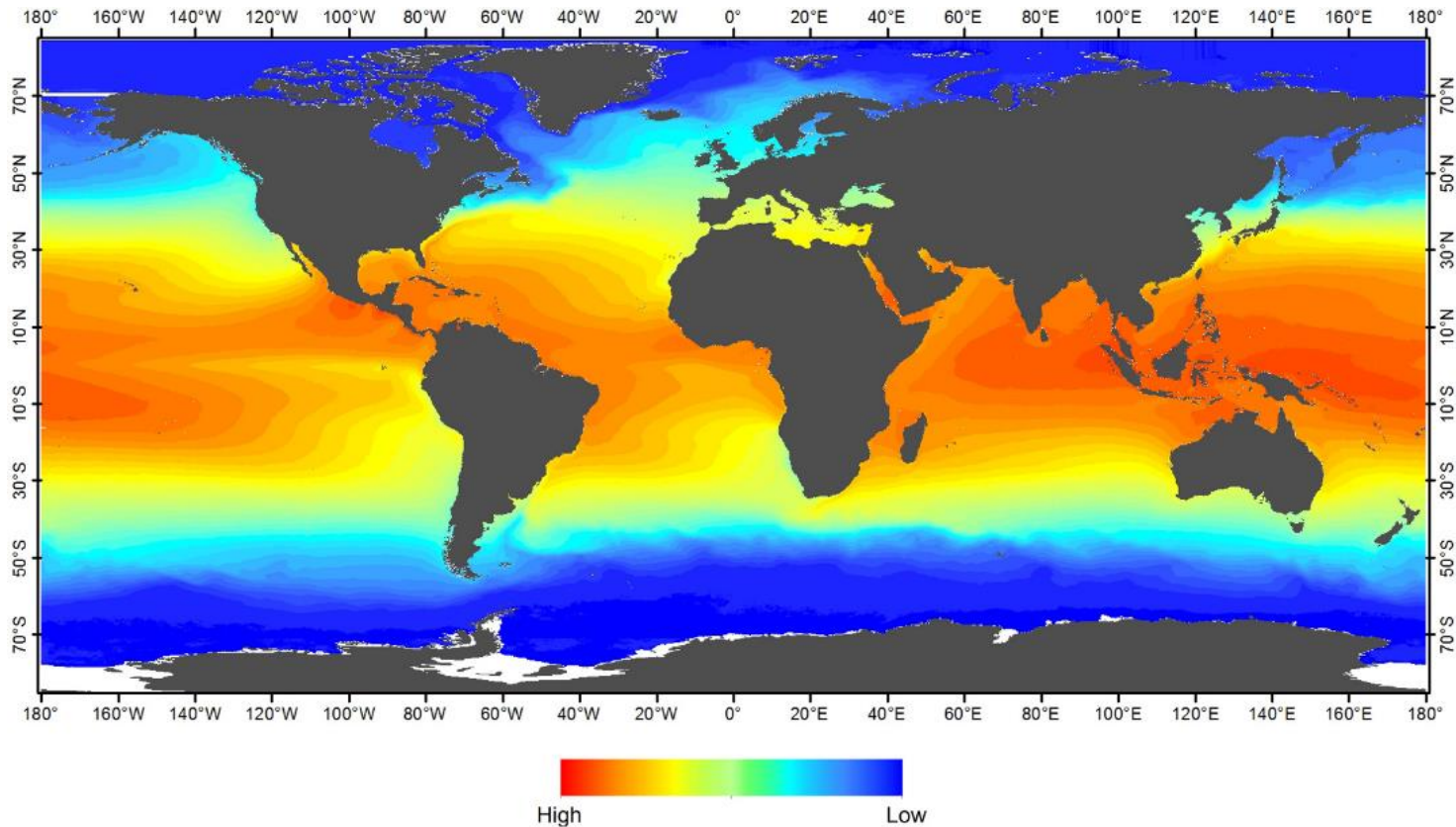

Figure A17. Sea Surface Temperature Maximum

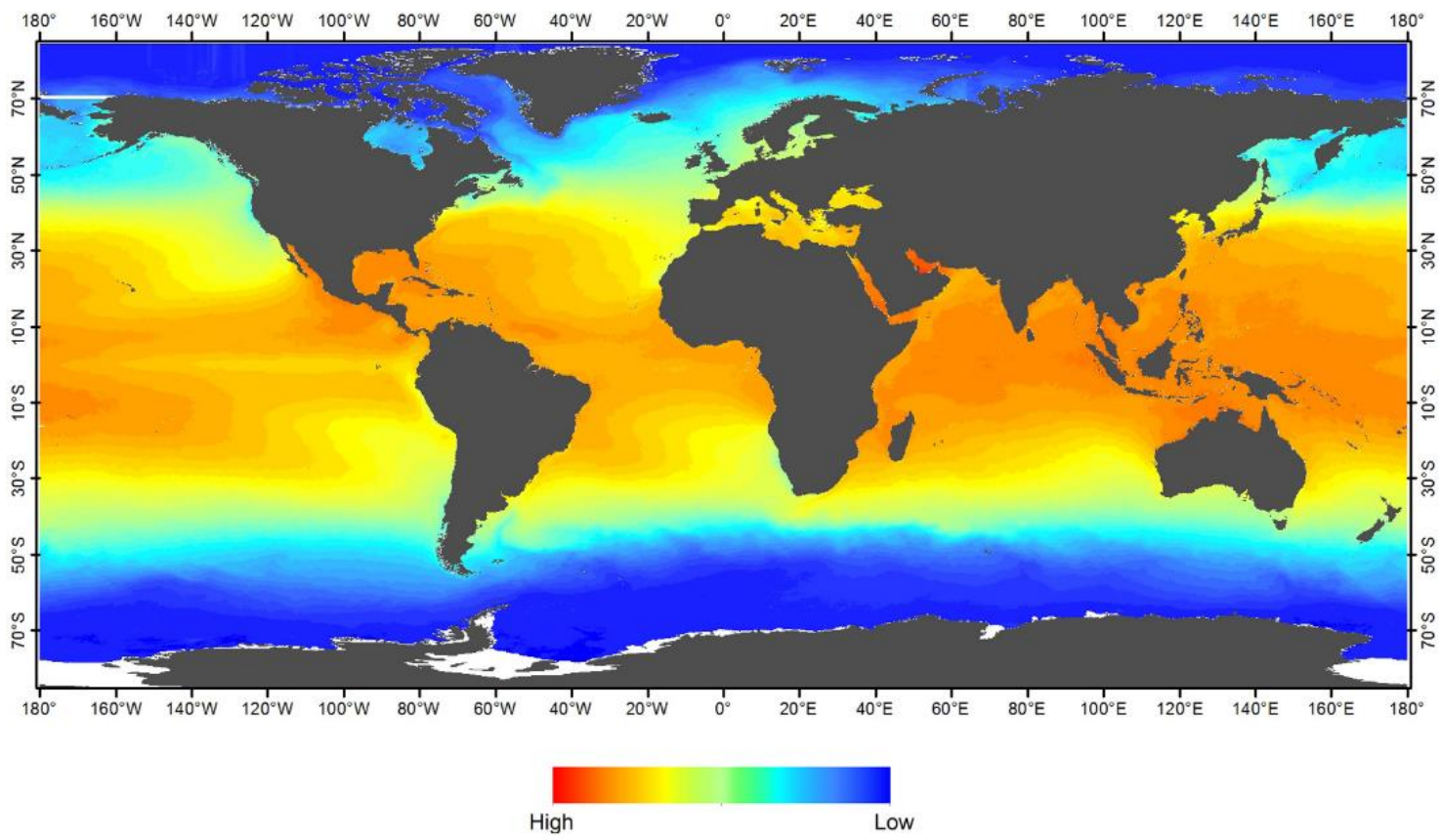

Figure A18. Sea Surface Temperature Minimum 
Earth Syst. Sci. Data Discuss., https://doi.org/10.5194/essd-2018-64

Manuscript under review for journal Earth Syst. Sci. Data

Discussion started: 27 July 2018

(c) Author(s) 2018. CC BY 4.0 License.

(c) (i)

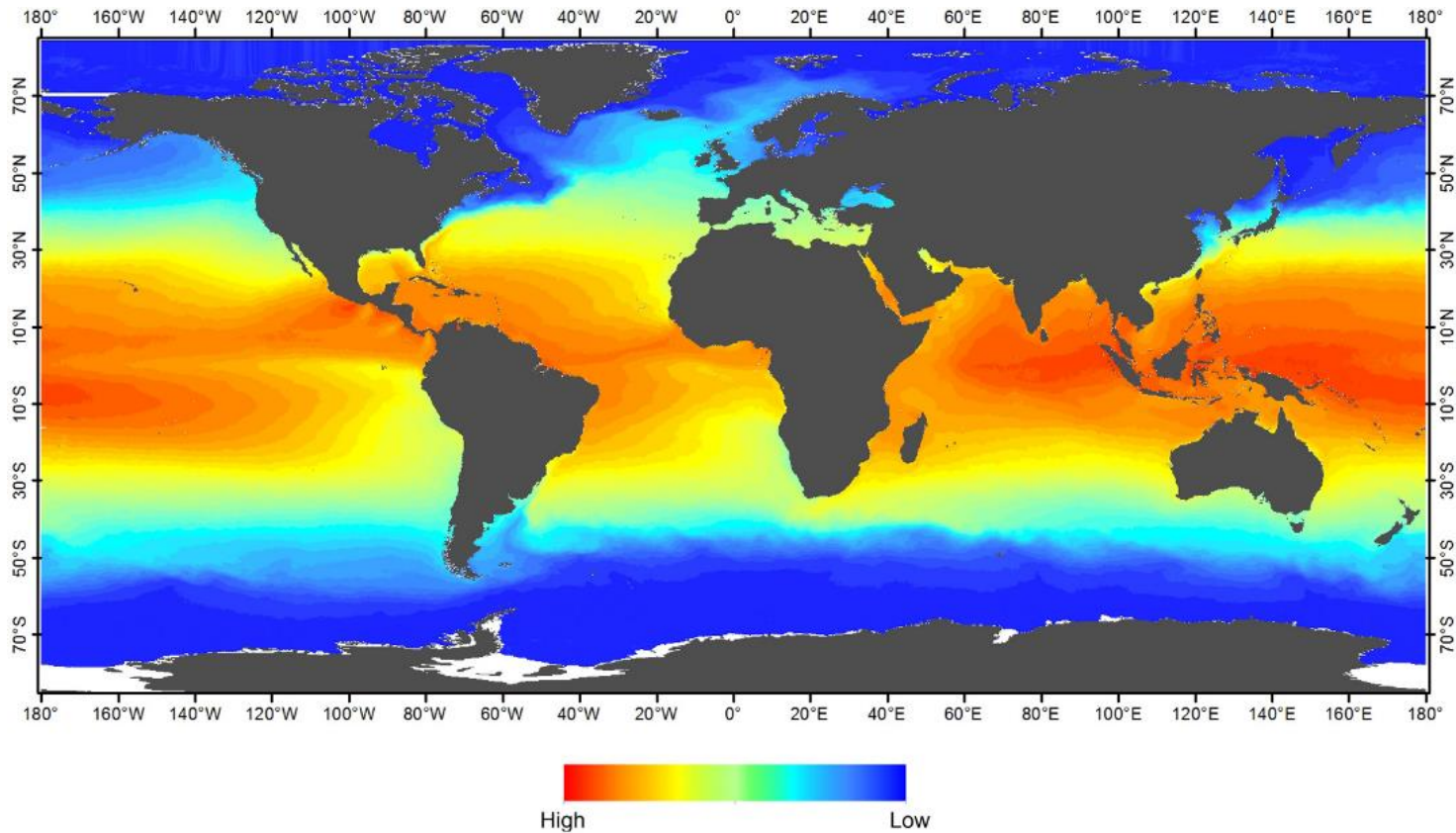

Figure A19. Sea Surface Temperature Range

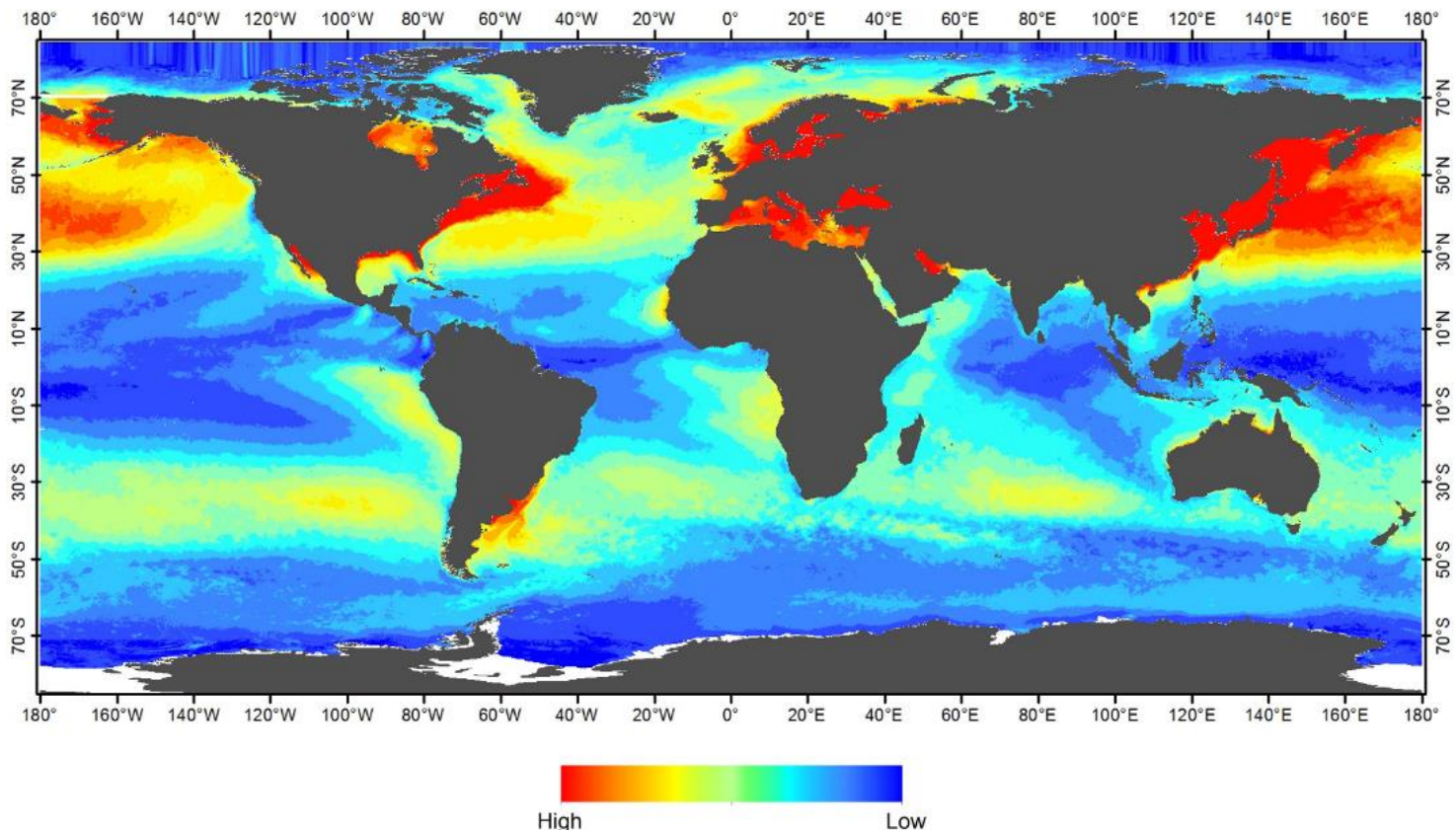


Earth Syst. Sci. Data Discuss., https://doi.org/10.5194/essd-2018-64

Manuscript under review for journal Earth Syst. Sci. Data

Discussion started: 27 July 2018

(c) Author(s) 2018. CC BY 4.0 License.

(c) (1)

Figure A20. Sea Surface Temperature (May-Oct)

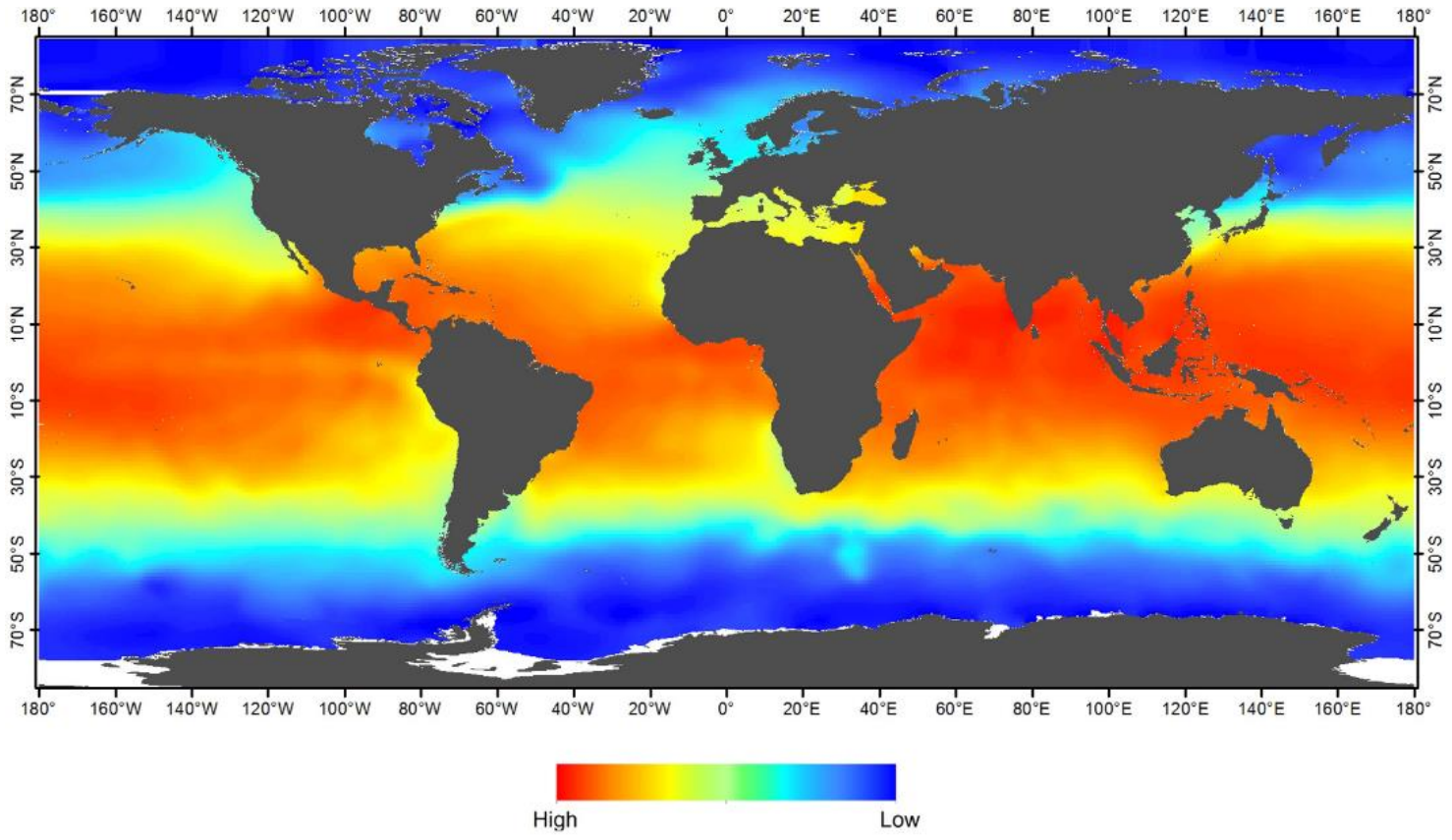

Figure A21. Sea Surface Temperature (Nov-Apr) 
Earth Syst. Sci. Data Discuss., https://doi.org/10.5194/essd-2018-64

Manuscript under review for journal Earth Syst. Sci. Data

Discussion started: 27 July 2018

(c) Author(s) 2018. CC BY 4.0 License.

(c) (9)

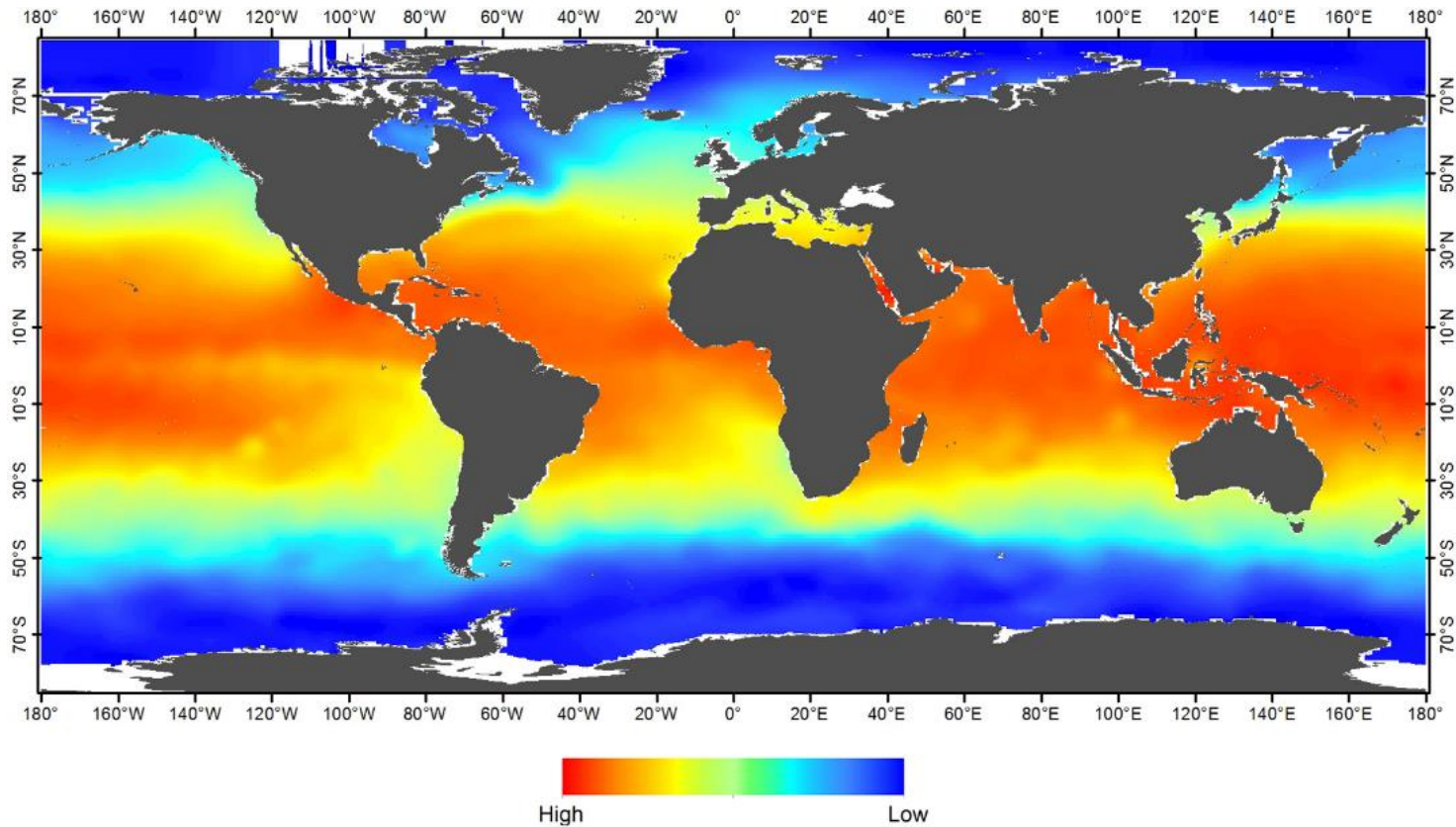

Figure A22. Seabed Temperature

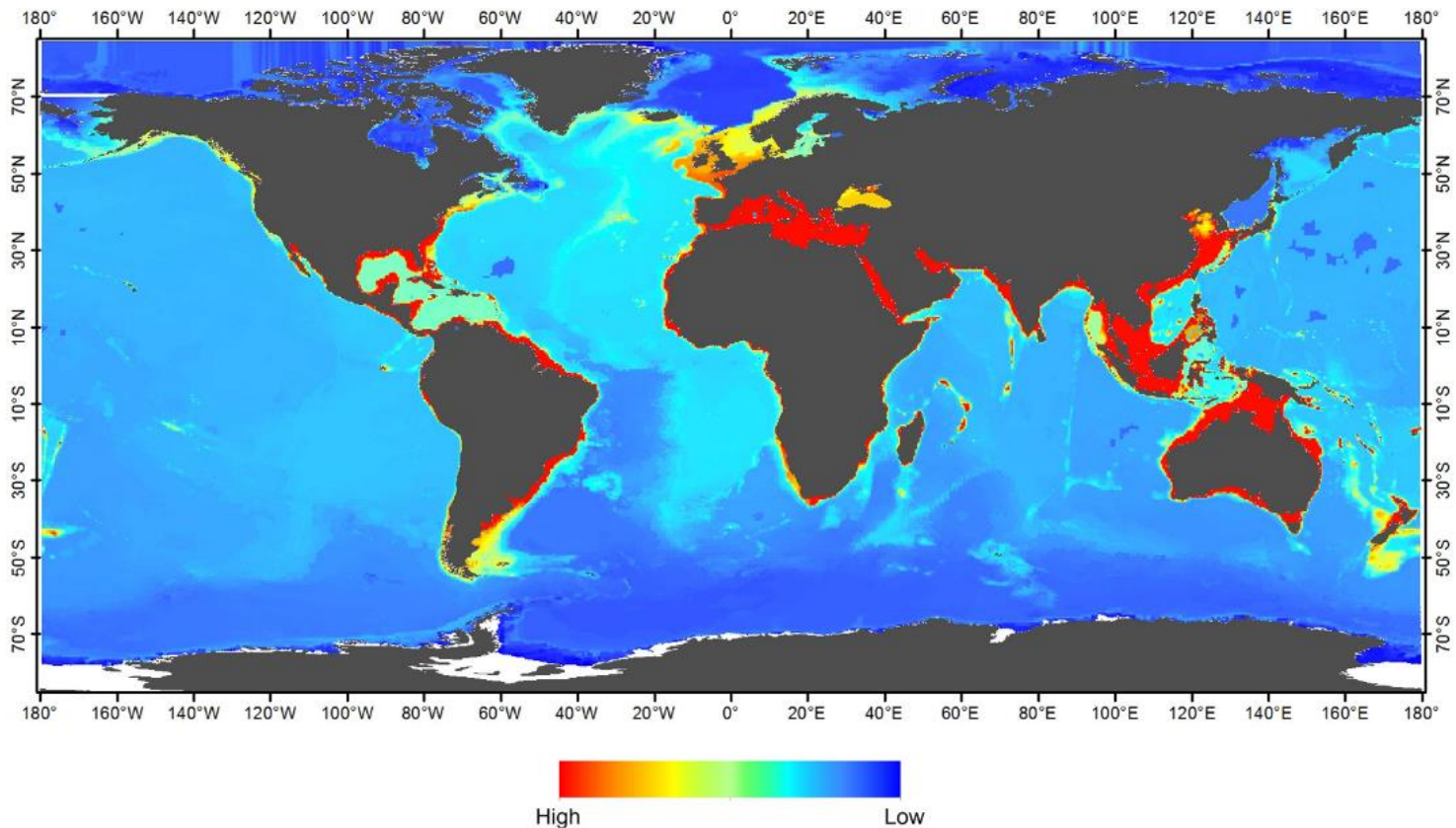

Figure A23. Water Column Temperature 
Earth Syst. Sci. Data Discuss., https://doi.org/10.5194/essd-2018-64

Manuscript under review for journal Earth Syst. Sci. Data

Discussion started: 27 July 2018

(c) Author(s) 2018. CC BY 4.0 License.

(c) (1)

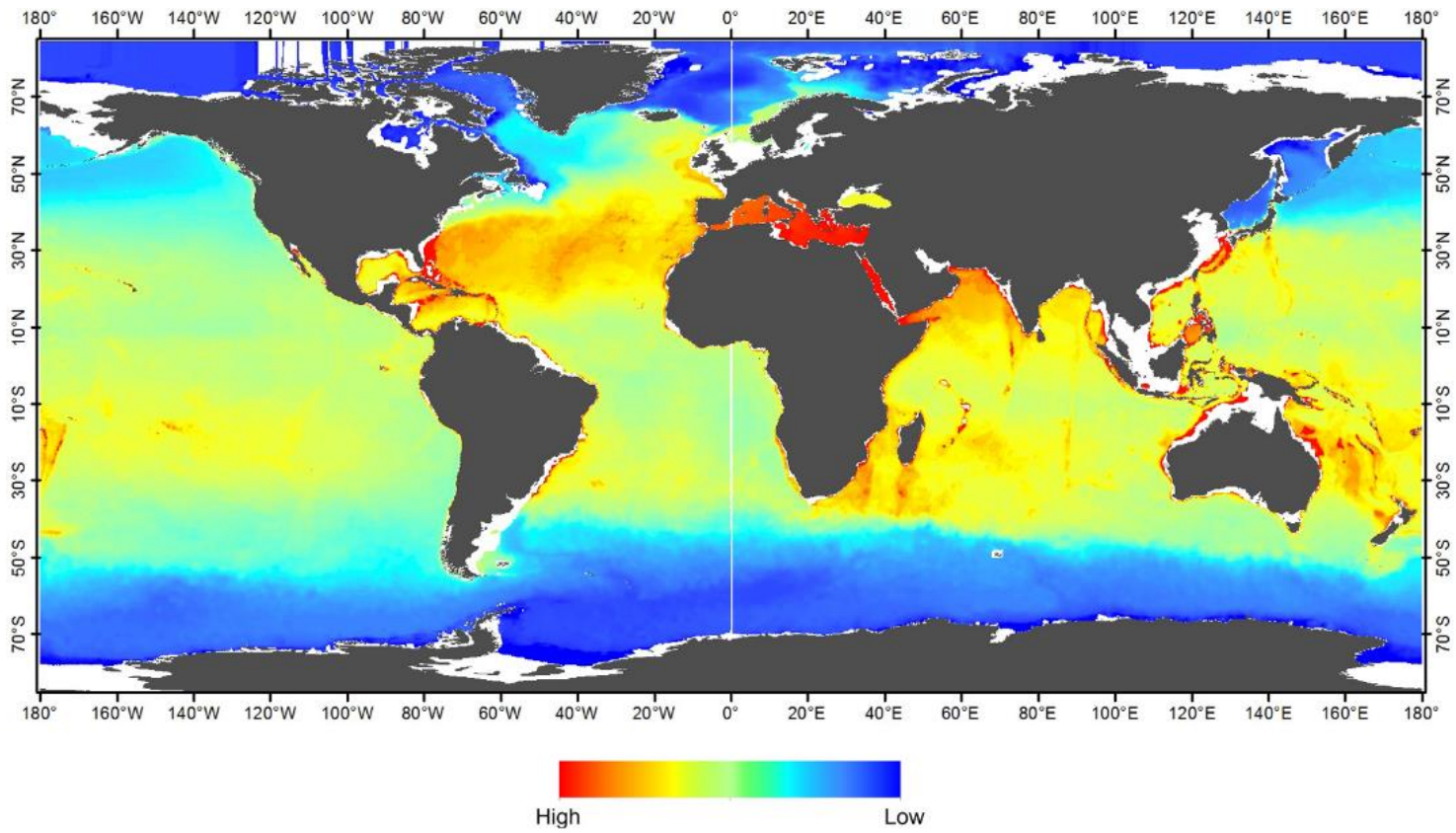

Figure A24. Surface Salinity

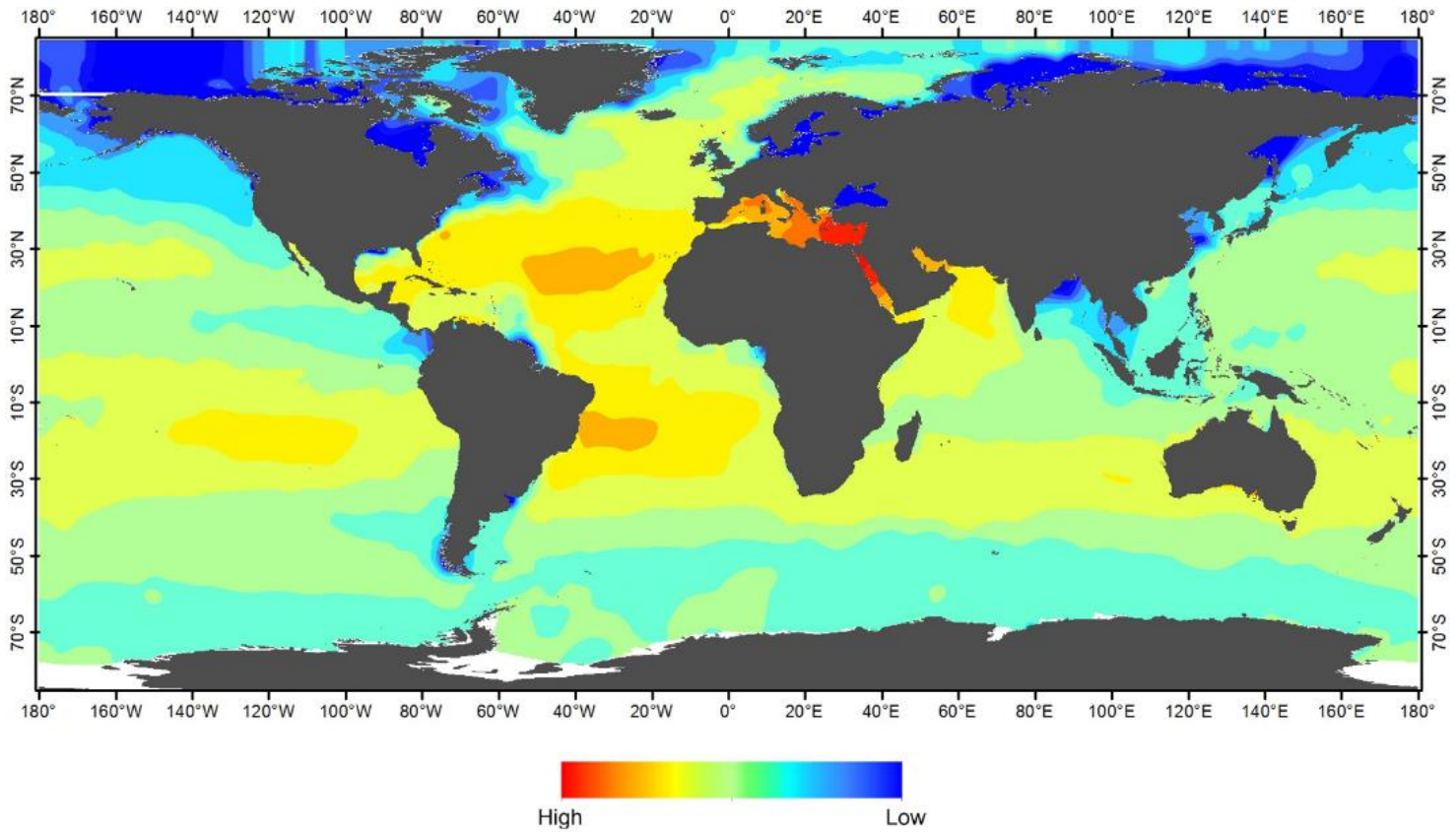


Earth Syst. Sci. Data Discuss., https://doi.org/10.5194/essd-2018-64

Manuscript under review for journal Earth Syst. Sci. Data

Discussion started: 27 July 2018

(c) Author(s) 2018. CC BY 4.0 License.

Figure A25. Water Column Salinity

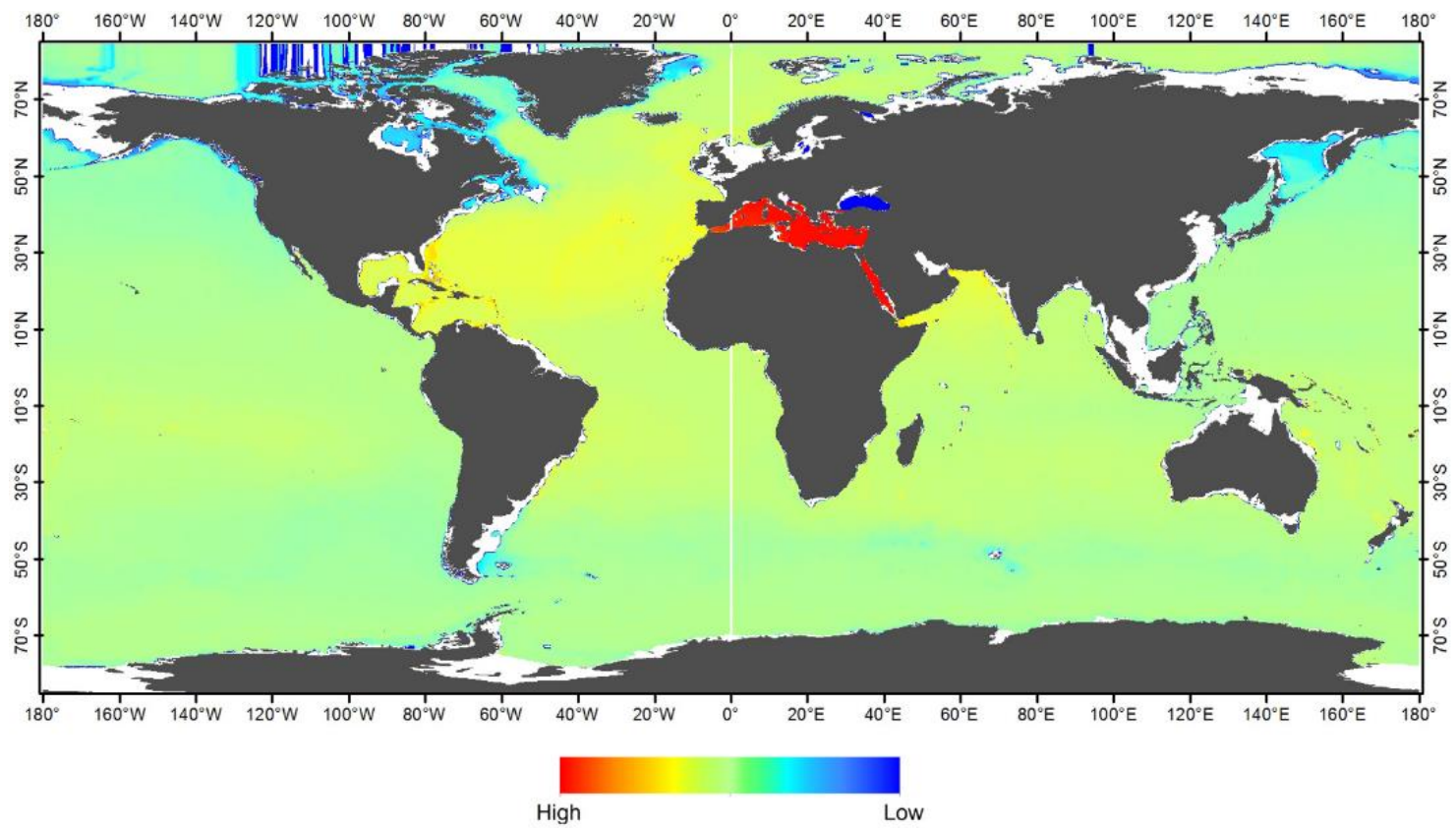

Figure A26. Photosynthetically Active Radiation 
Earth Syst. Sci. Data Discuss., https://doi.org/10.5194/essd-2018-64

Manuscript under review for journal Earth Syst. Sci. Data

Discussion started: 27 July 2018

(c) Author(s) 2018. CC BY 4.0 License.

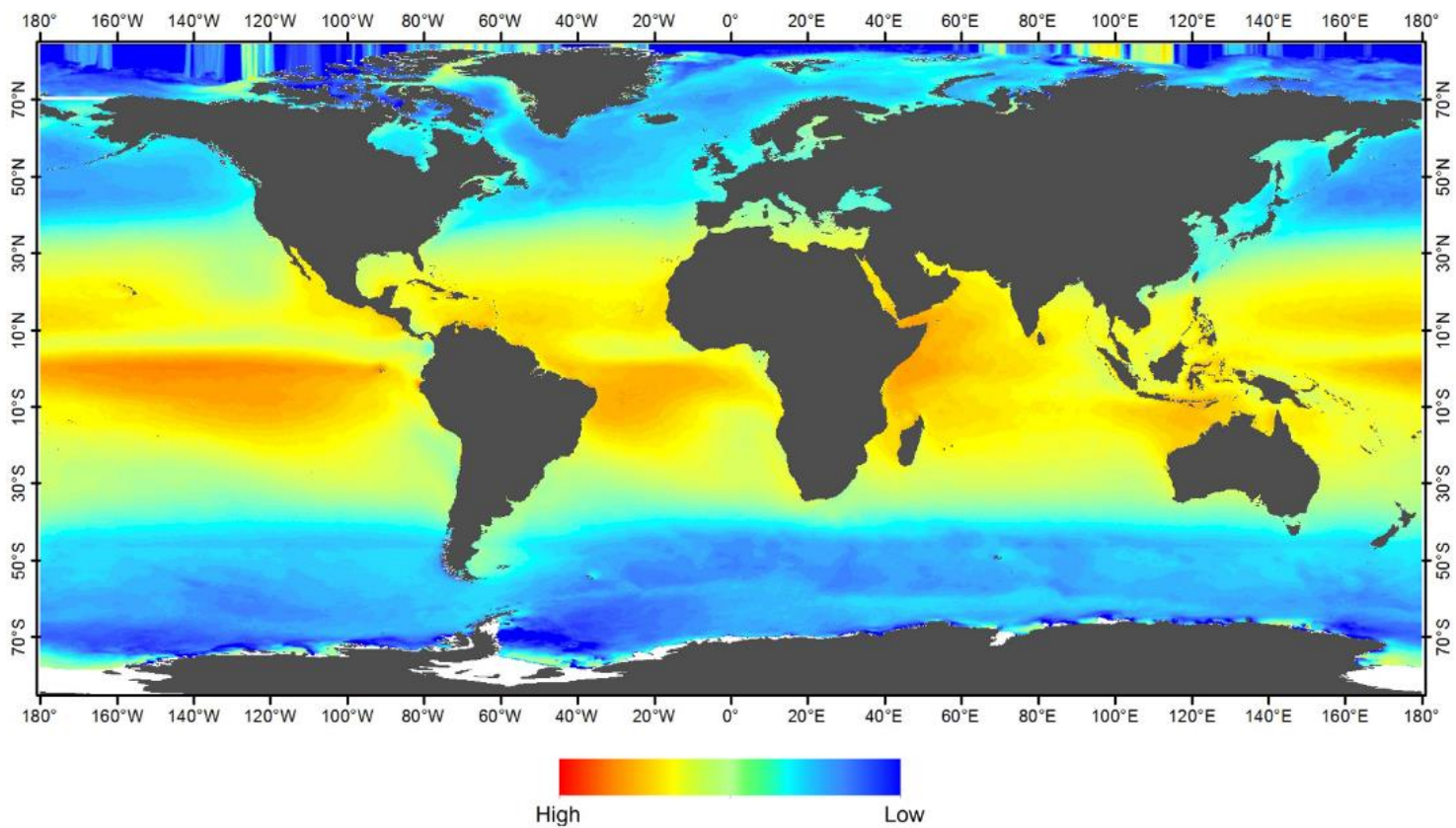

\section{Chemical}

Figure A27. Chlorophyll-a Mean

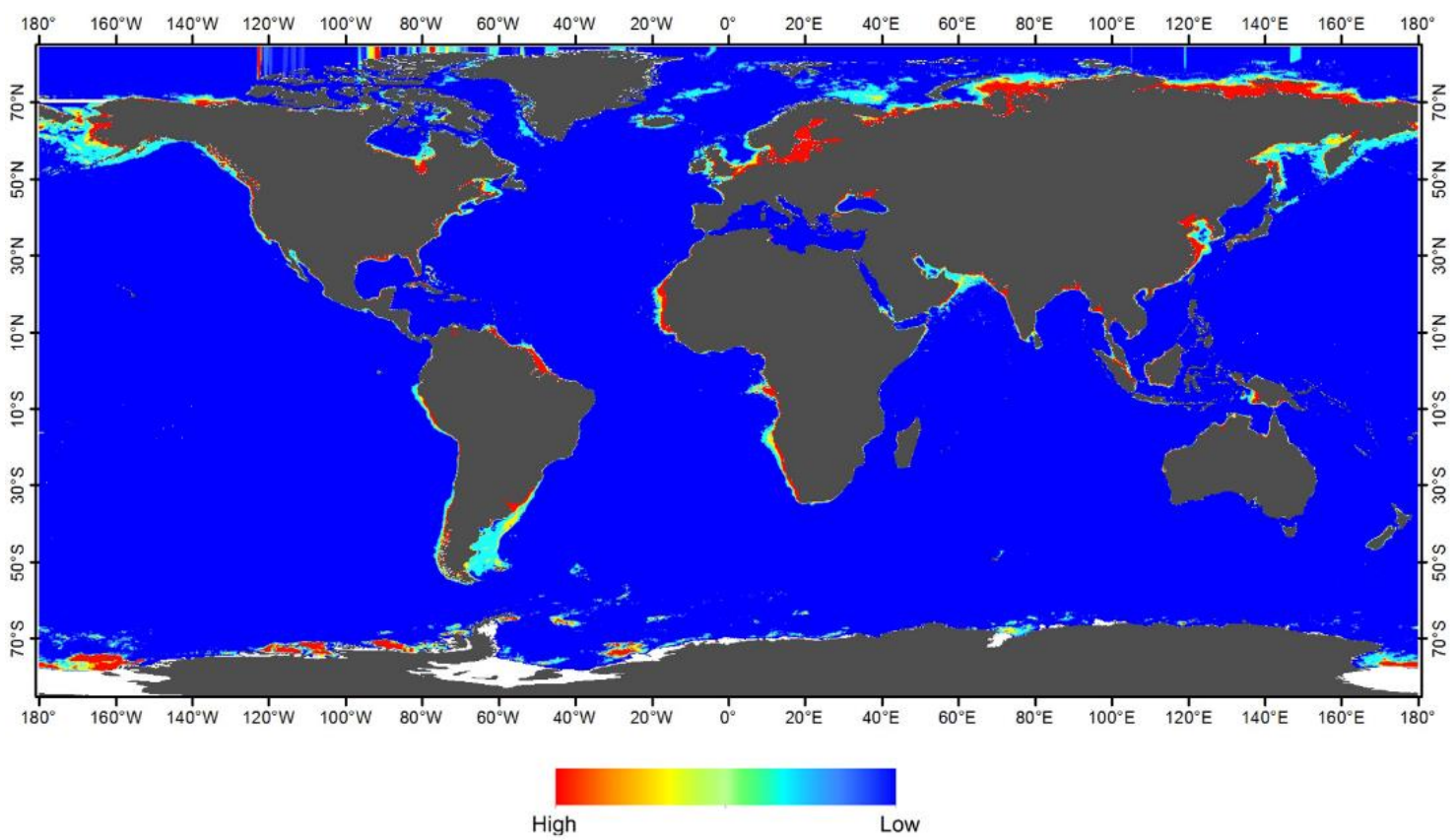


Earth Syst. Sci. Data Discuss., https://doi.org/10.5194/essd-2018-64

Manuscript under review for journal Earth Syst. Sci. Data

Discussion started: 27 July 2018

(c) Author(s) 2018. CC BY 4.0 License.

Figure A28. Chlorophyll-a Maximum

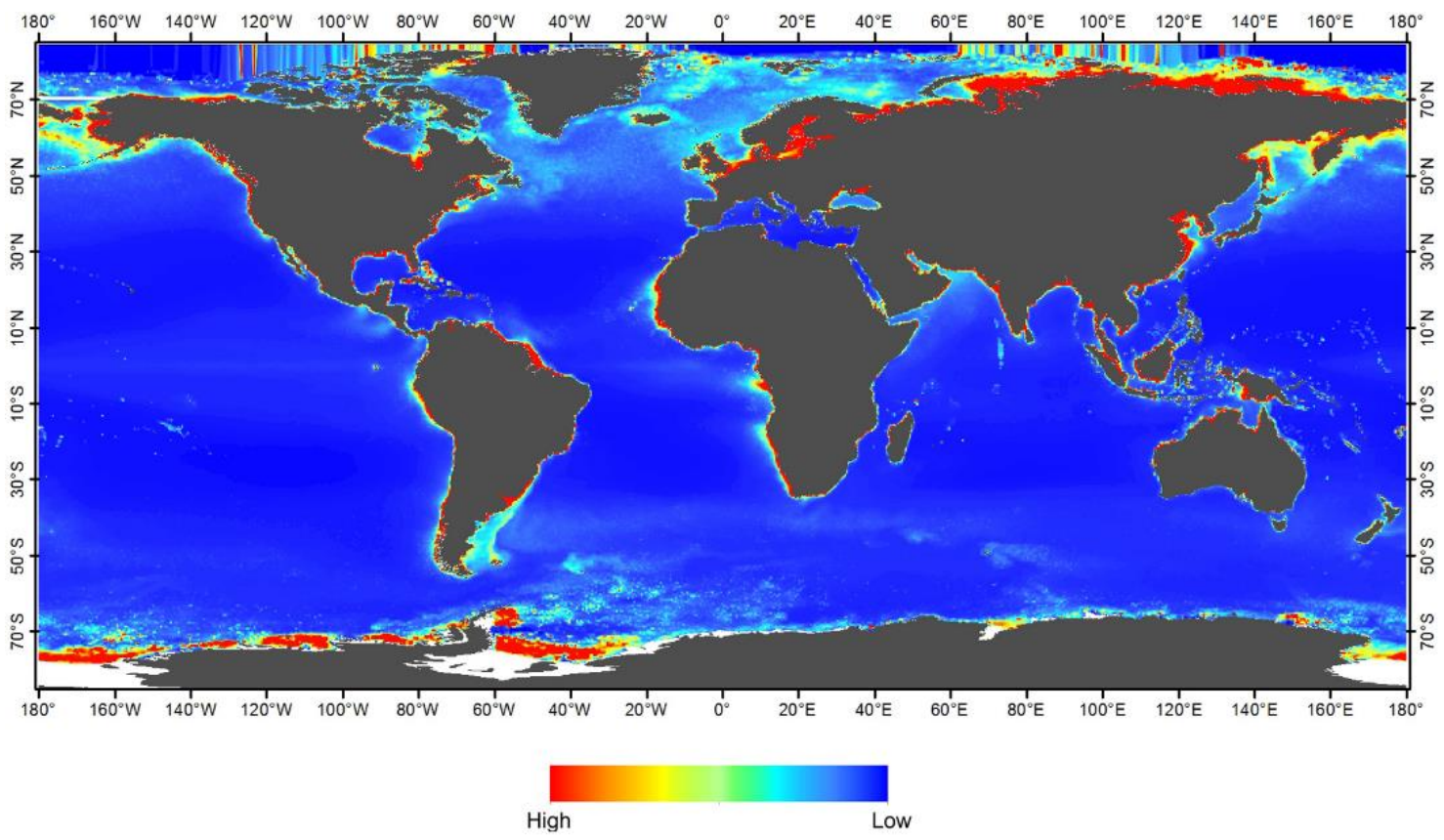

Figure A29. Chlorophyll-a Minimum

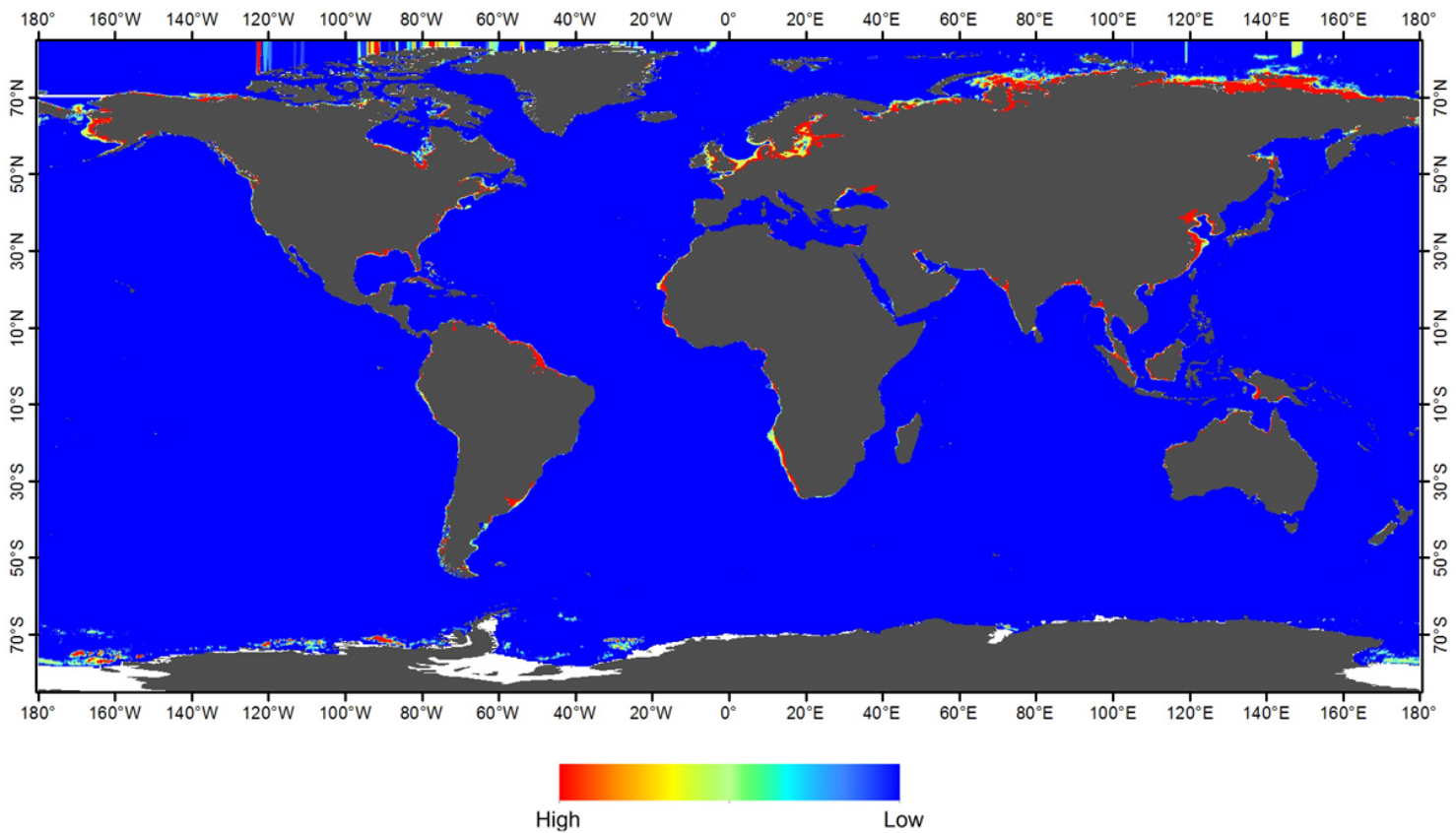


Earth Syst. Sci. Data Discuss., https://doi.org/10.5194/essd-2018-64

Manuscript under review for journal Earth Syst. Sci. Data

Discussion started: 27 July 2018

(c) Author(s) 2018. CC BY 4.0 License.

Figure A30. Chlorophyll-a Range

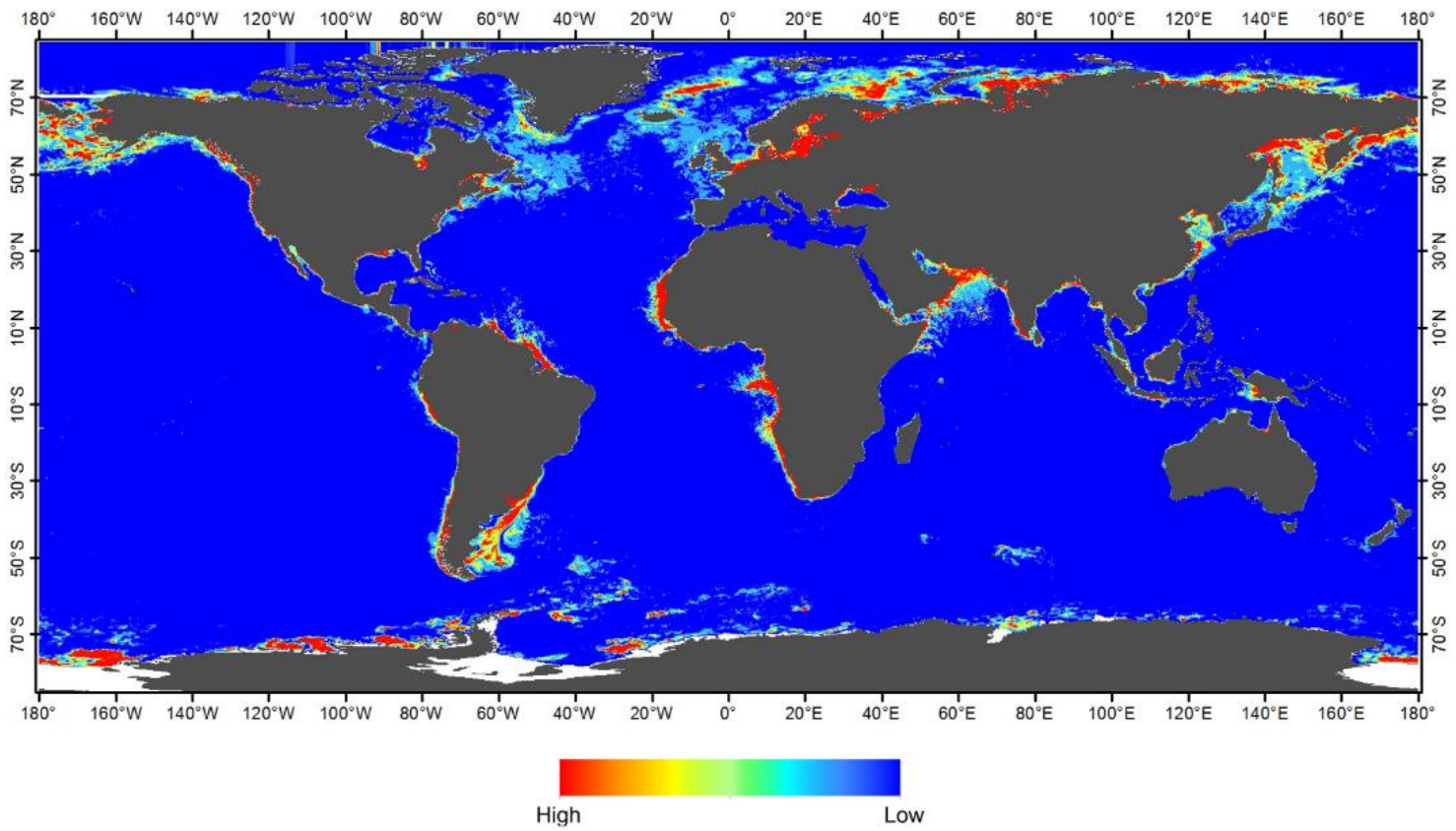

Figure A31. Chlorophyll-a (May-Oct) Maximum

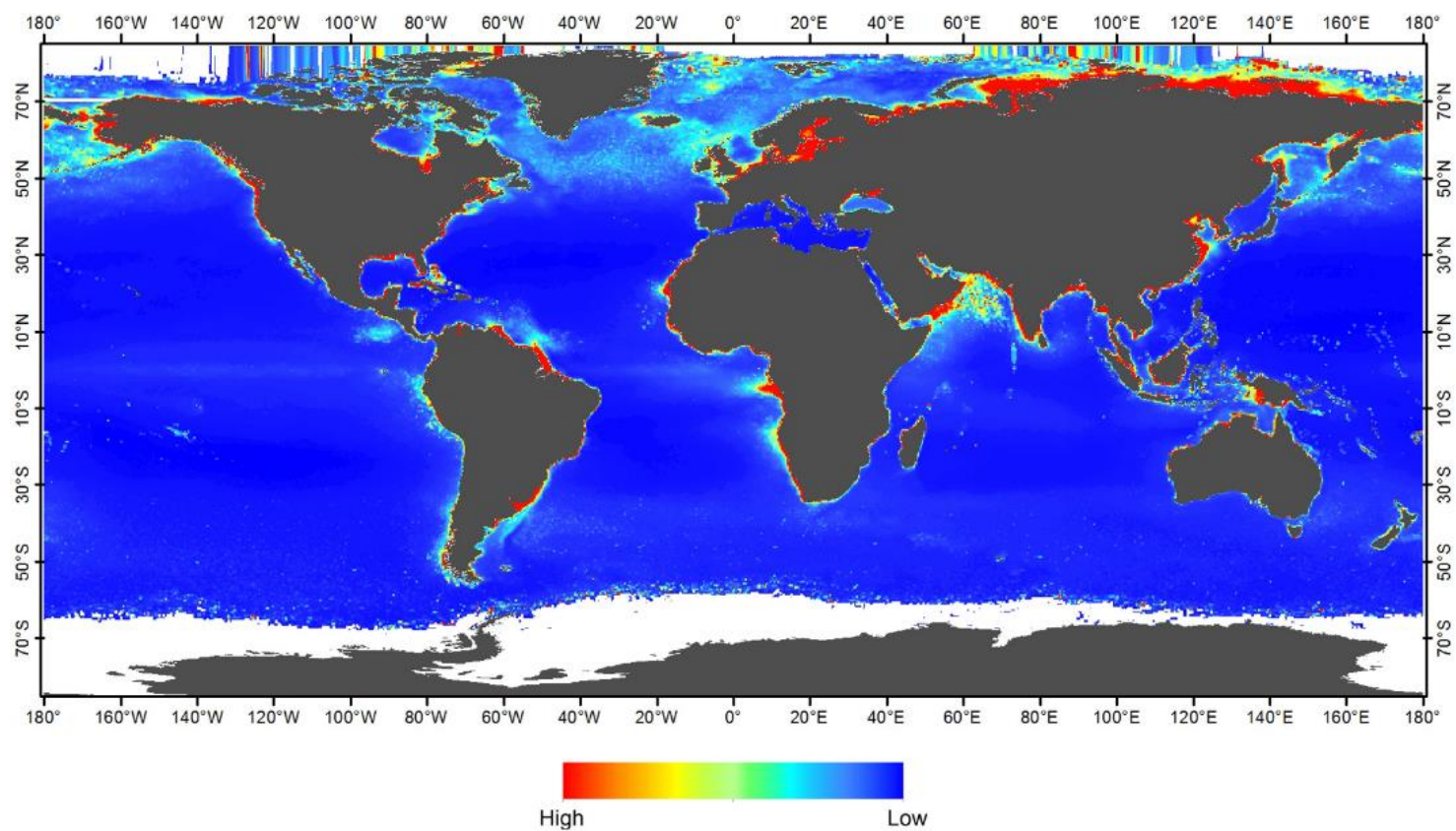


Earth Syst. Sci. Data Discuss., https://doi.org/10.5194/essd-2018-64

Manuscript under review for journal Earth Syst. Sci. Data

Discussion started: 27 July 2018

(c) Author(s) 2018. CC BY 4.0 License.

Figure A32. Chlorophyll-a (Nov-Apr) Maximum

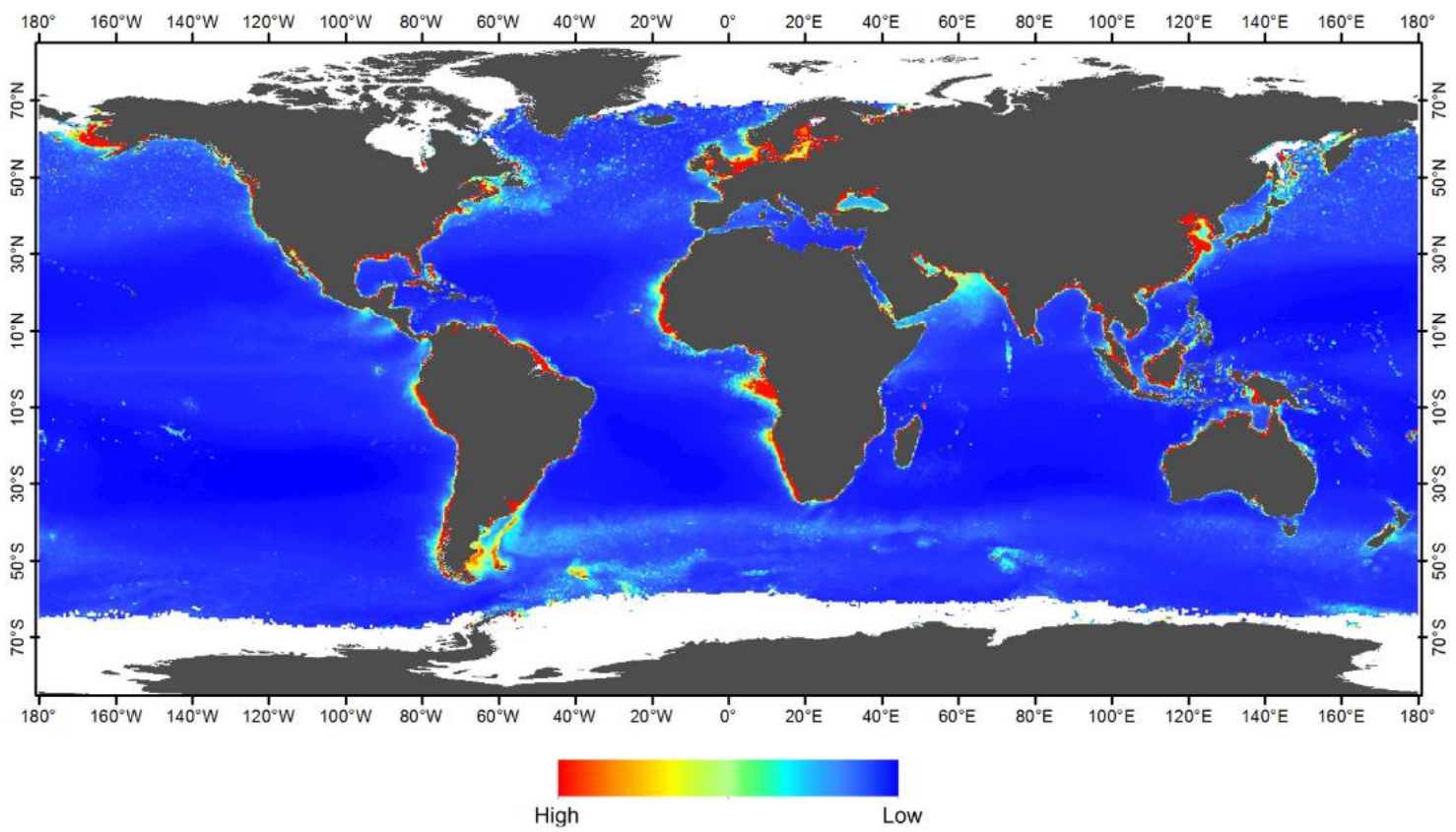

Figure A33. Primary Productivity

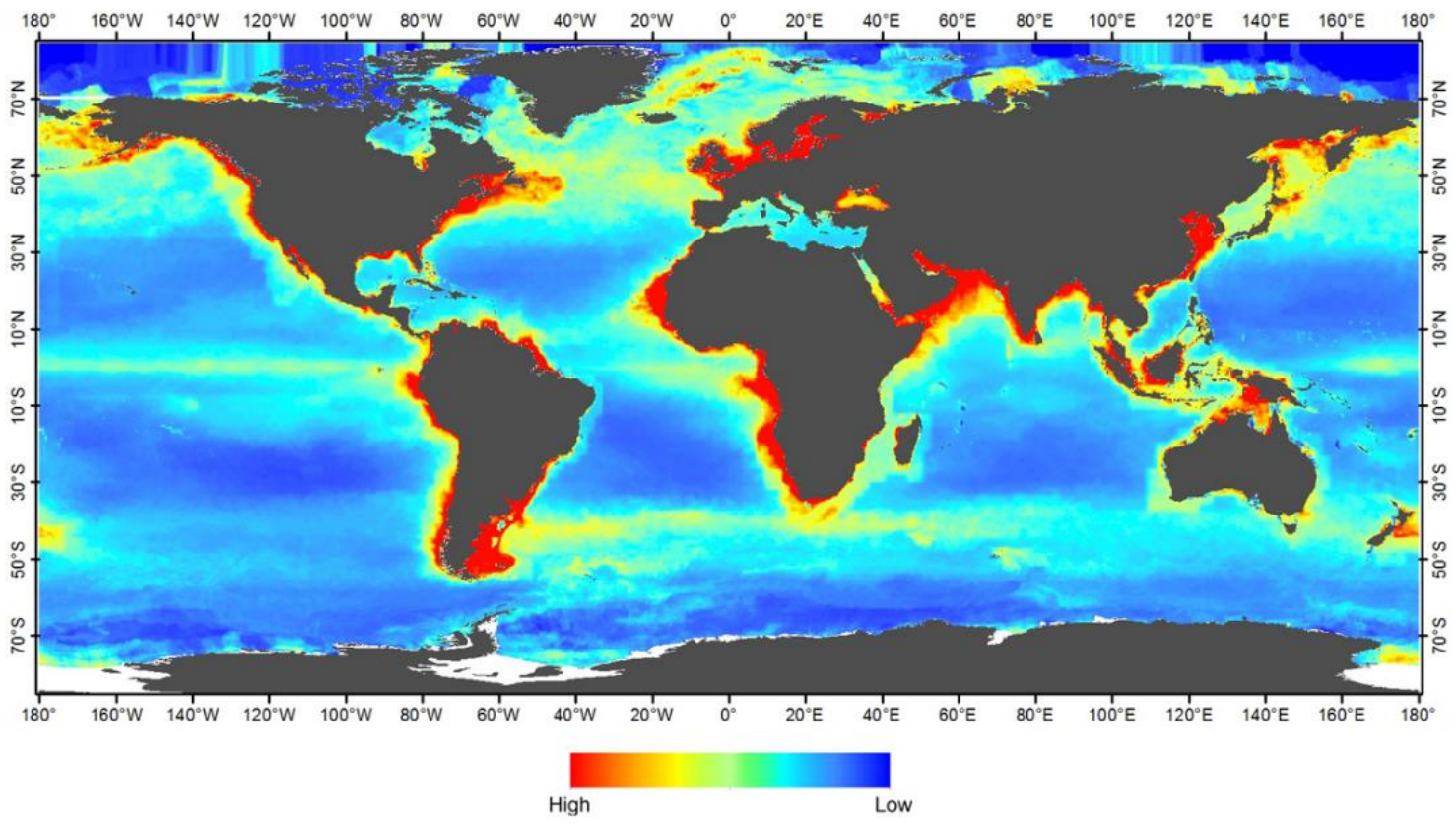


Earth Syst. Sci. Data Discuss., https://doi.org/10.5194/essd-2018-64

Manuscript under review for journal Earth Syst. Sci. Data

Discussion started: 27 July 2018

(c) Author(s) 2018. CC BY 4.0 License.

Figure A34. pH

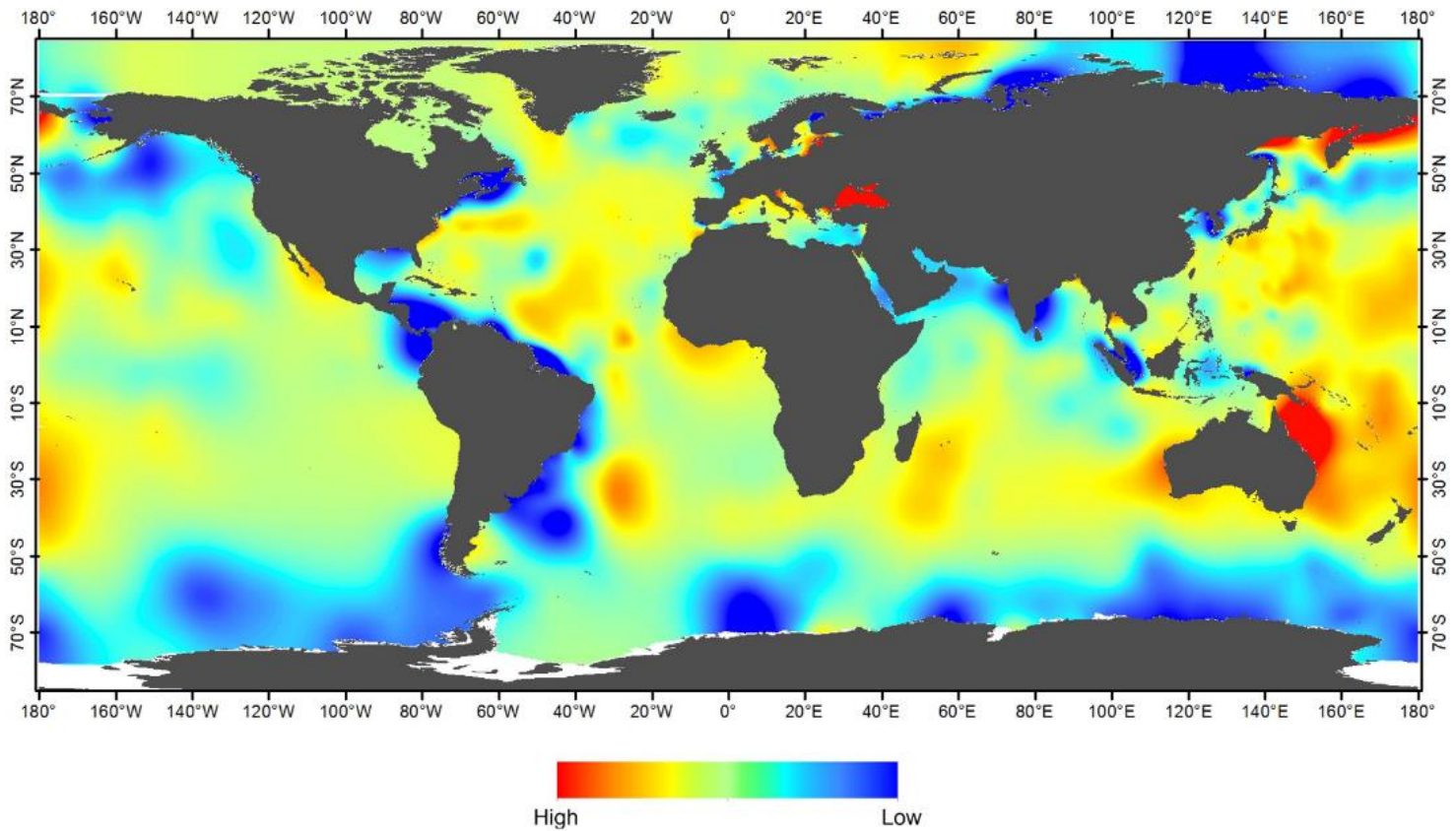

Figure A35. Total Suspended Matter 
Earth Syst. Sci. Data Discuss., https://doi.org/10.5194/essd-2018-64

Manuscript under review for journal Earth Syst. Sci. Data

Discussion started: 27 July 2018

(c) Author(s) 2018. CC BY 4.0 License.

(c) (i)

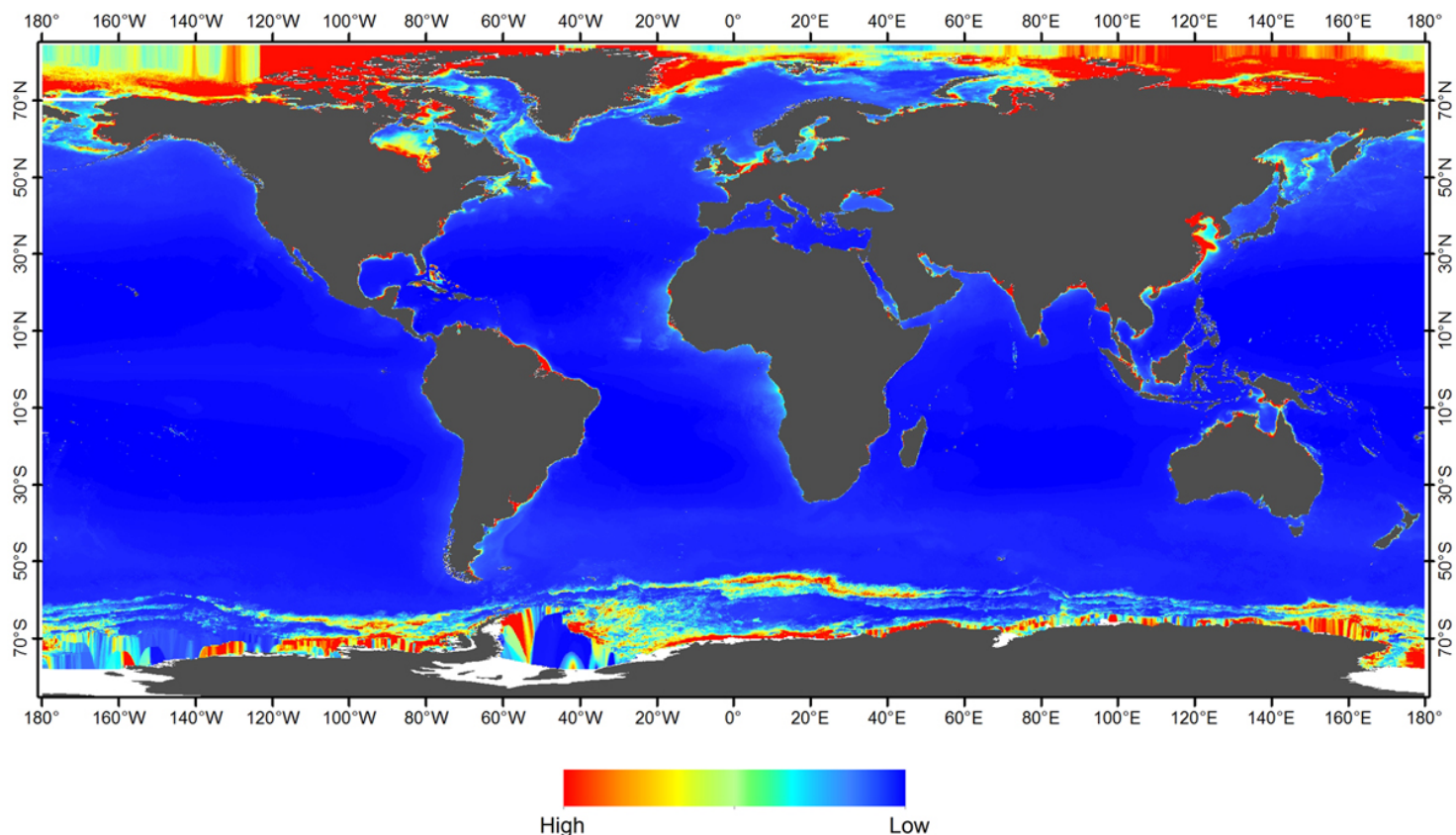


Earth Syst. Sci. Data Discuss., https://doi.org/10.5194/essd-2018-64

Manuscript under review for journal Earth Syst. Sci. Data

Discussion started: 27 July 2018

(c) Author(s) 2018. CC BY 4.0 License.

(c) (i)

\section{Nutrients}

Figure A36. Calcite

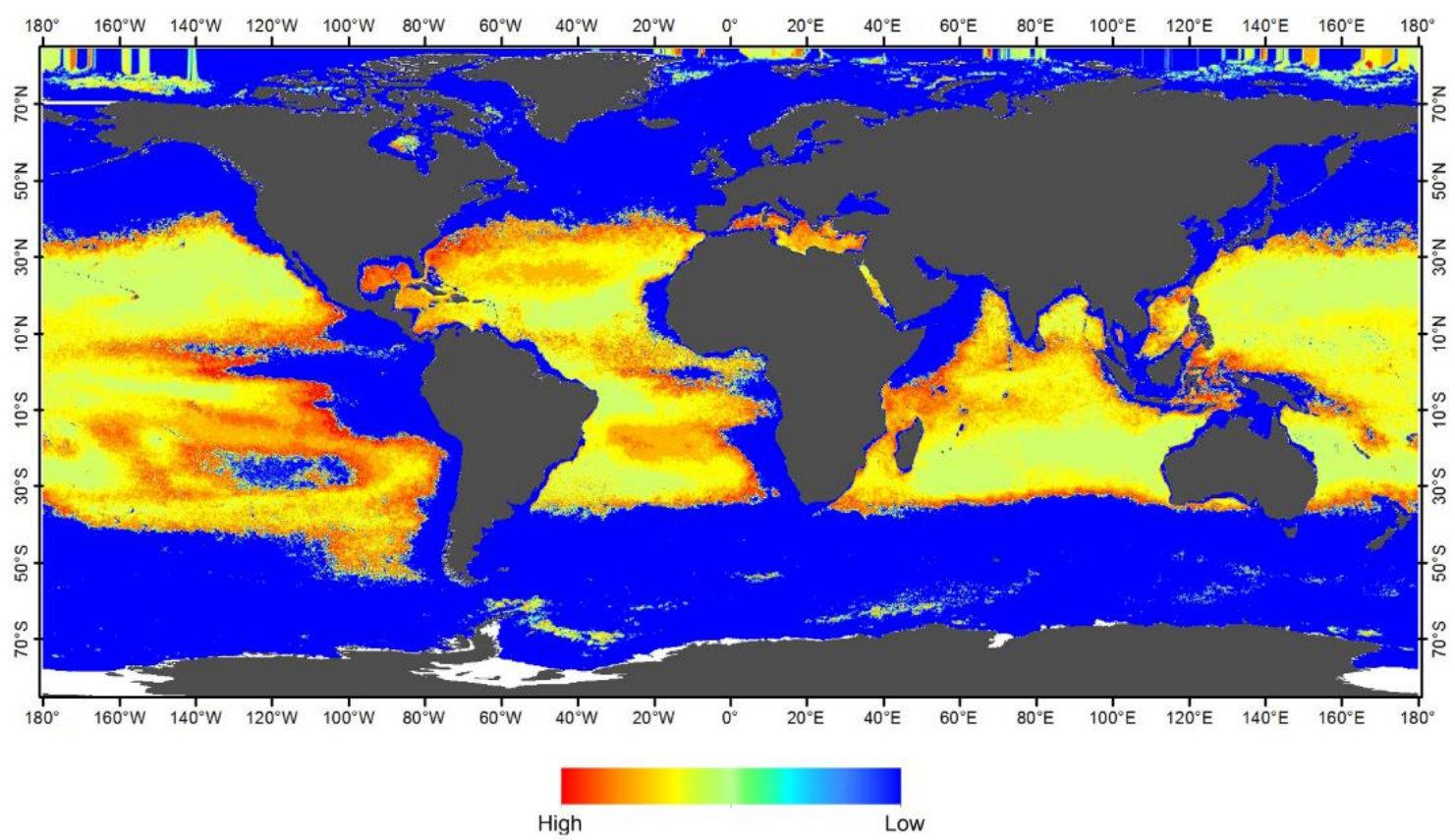

Figure A37. Nitrate

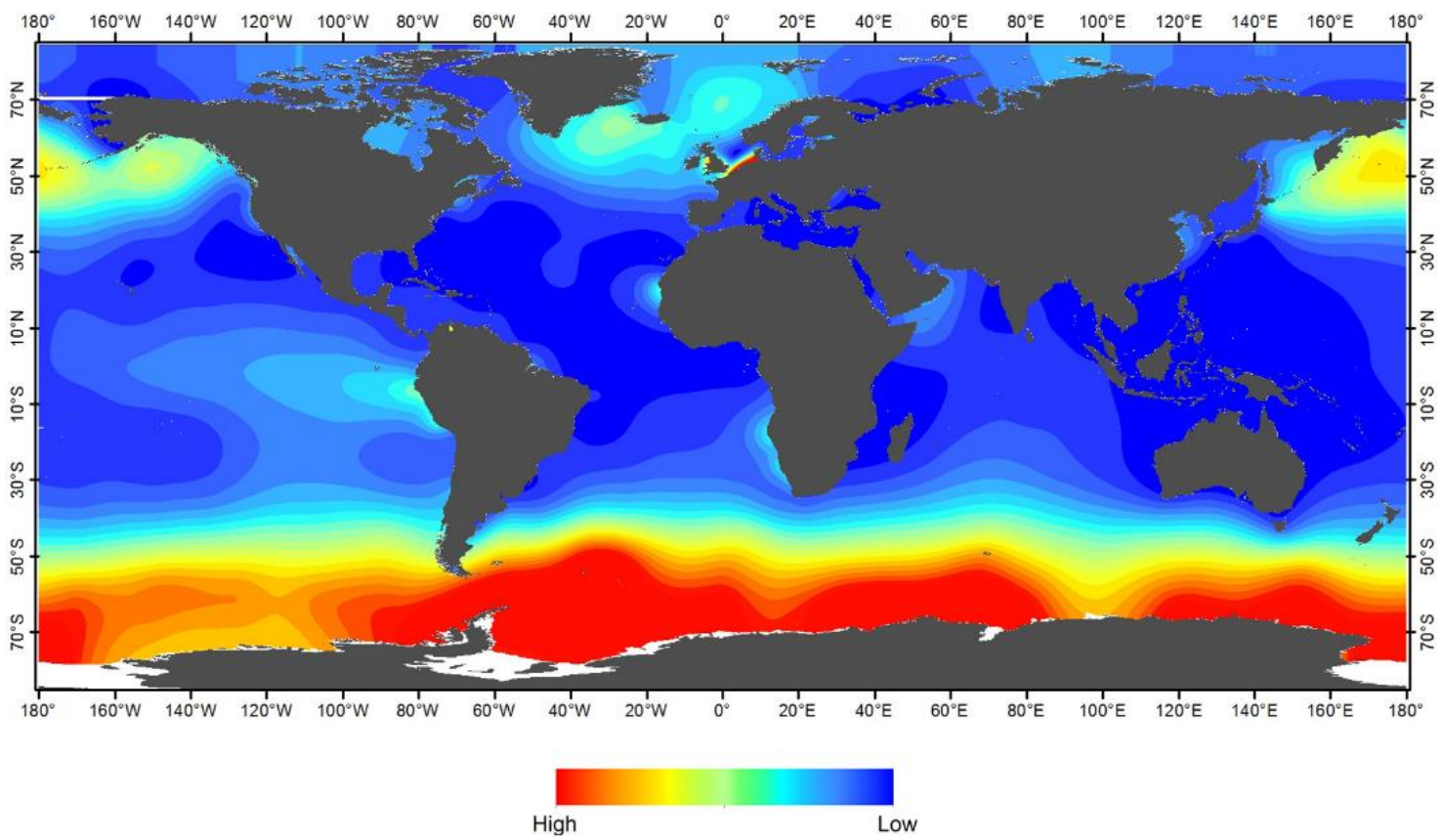


Earth Syst. Sci. Data Discuss., https://doi.org/10.5194/essd-2018-64

Manuscript under review for journal Earth Syst. Sci. Data

Discussion started: 27 July 2018

(c) Author(s) 2018. CC BY 4.0 License.

(c) (i)

Figure A38. Seabed Nitrate

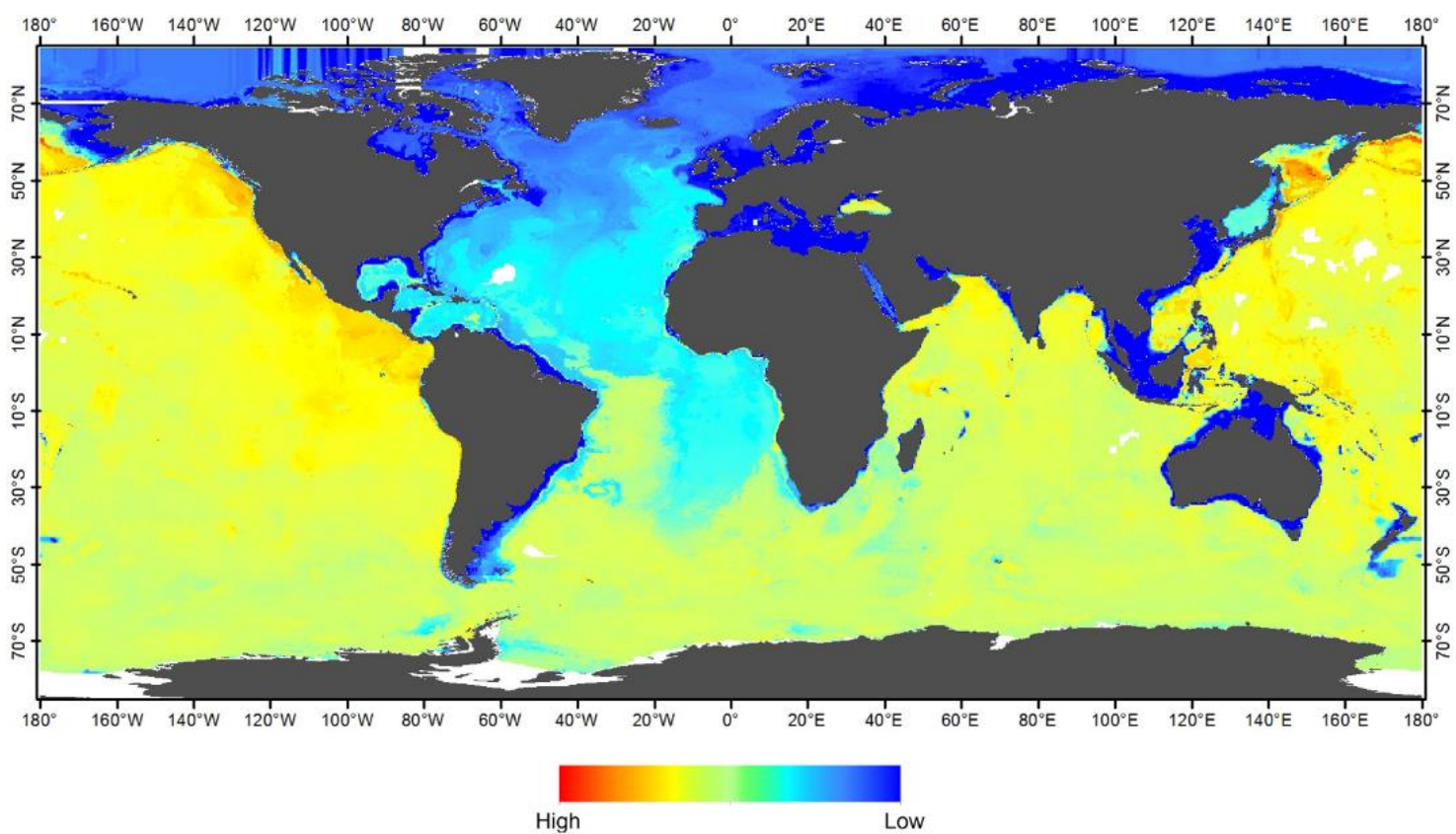

Figure A39. Phosphate

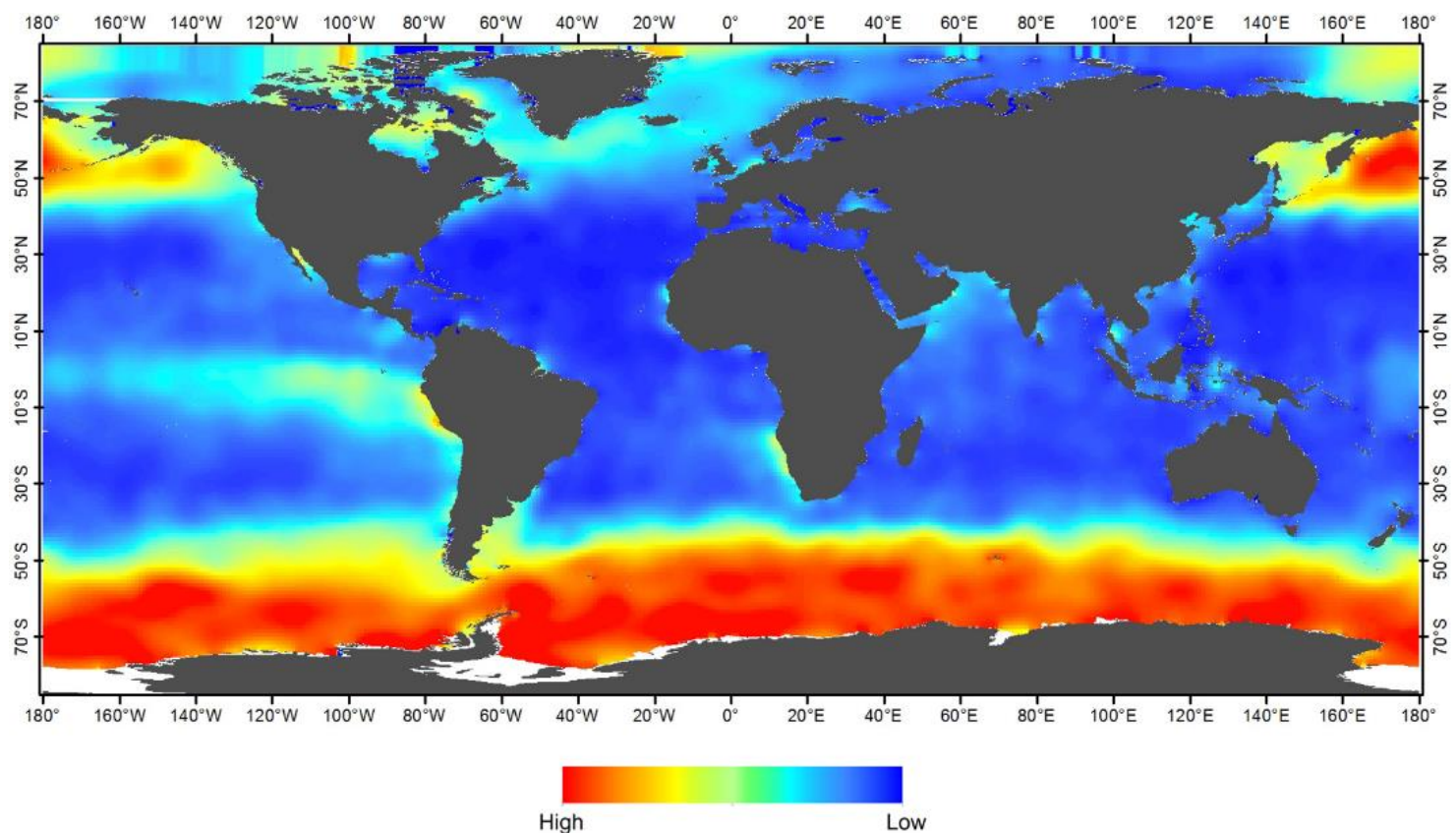


Earth Syst. Sci. Data Discuss., https://doi.org/10.5194/essd-2018-64

Manuscript under review for journal Earth Syst. Sci. Data

Discussion started: 27 July 2018

(c) Author(s) 2018. CC BY 4.0 License.

(c) (1)

Figure A40. Seabed Phosphate

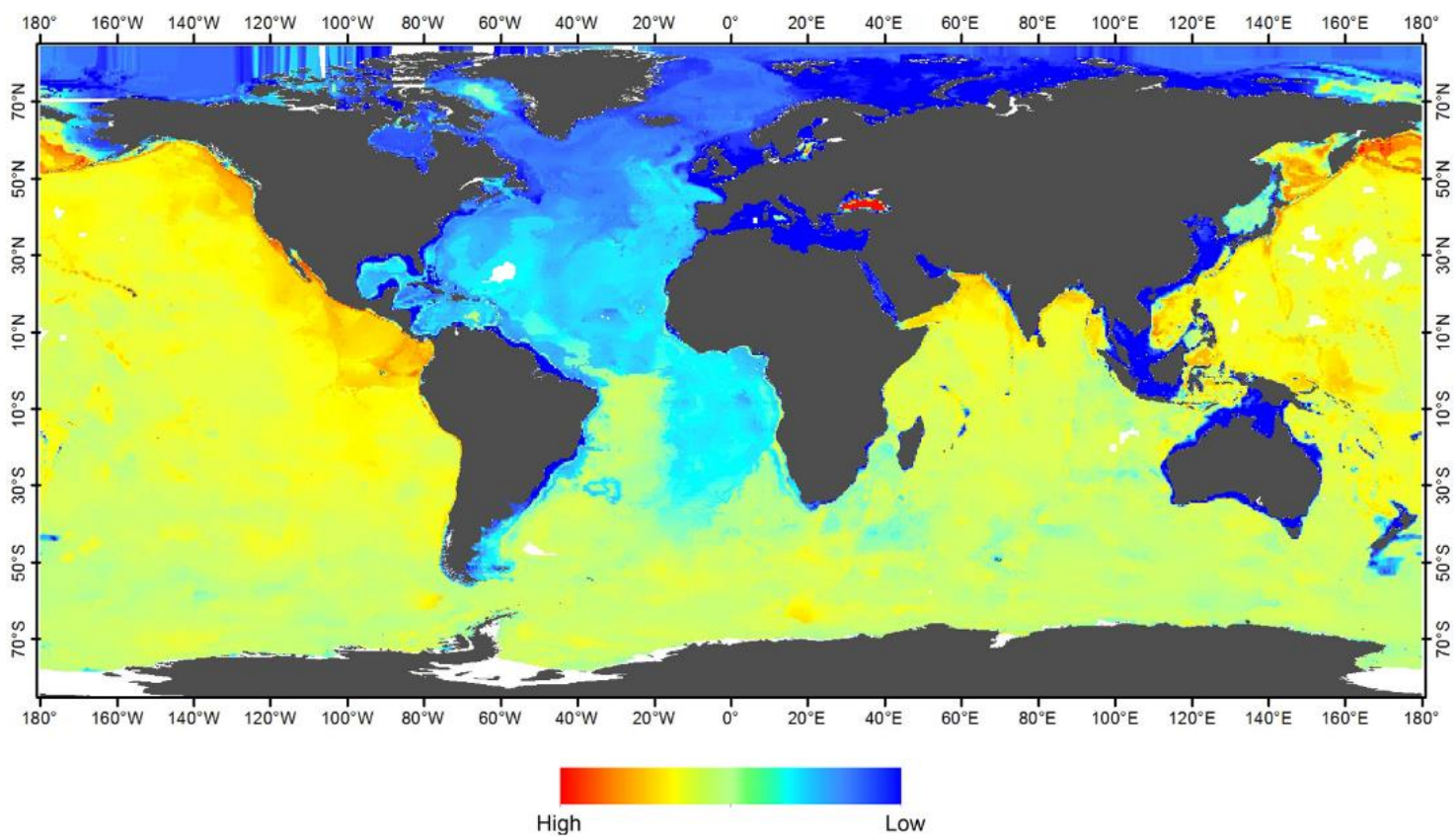

Figure A41. Silicate

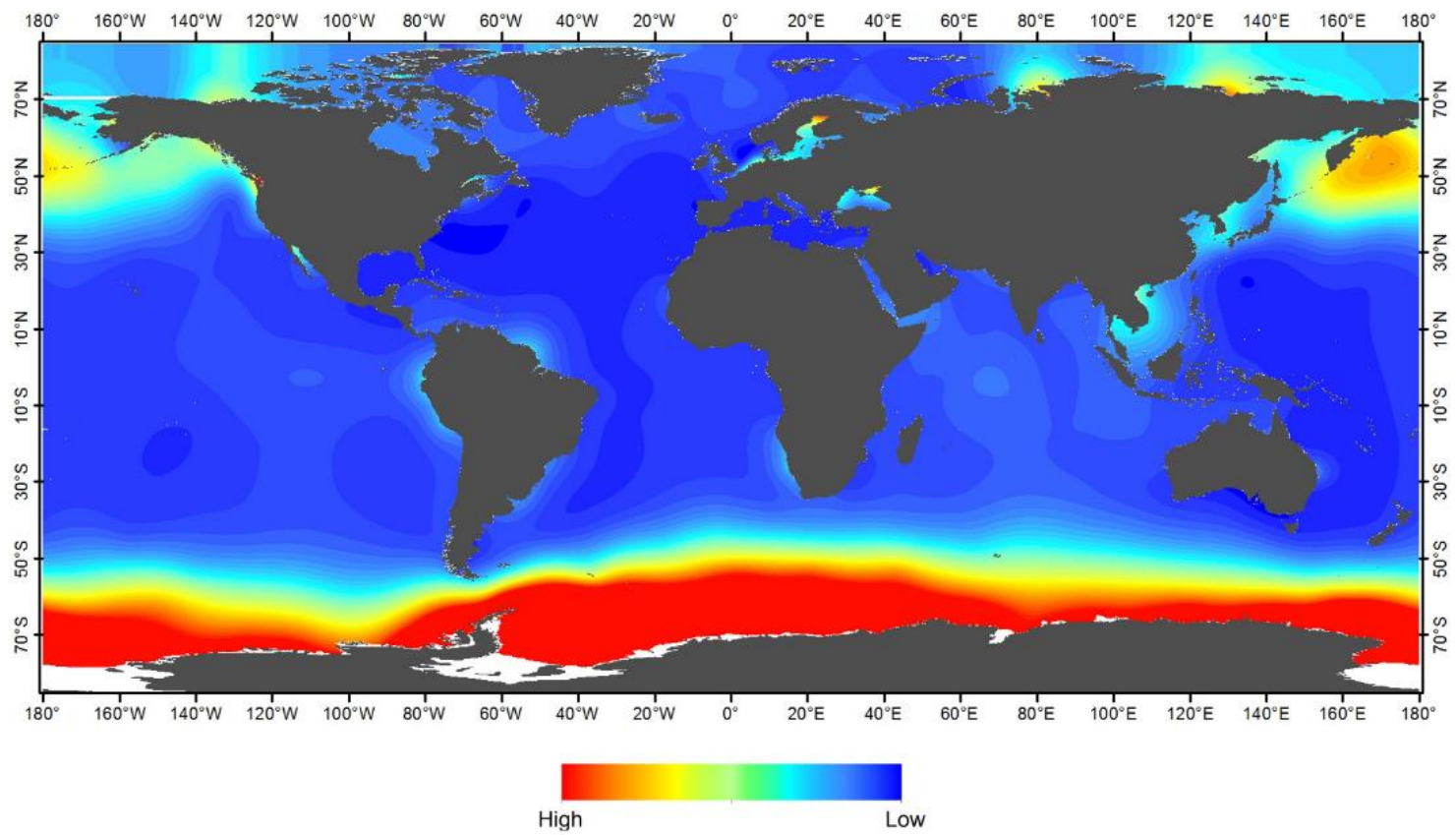


Earth Syst. Sci. Data Discuss., https://doi.org/10.5194/essd-2018-64

Manuscript under review for journal Earth Syst. Sci. Data

Discussion started: 27 July 2018

(c) Author(s) 2018. CC BY 4.0 License.

(c) (1)

Figure A42. Seabed Silicate

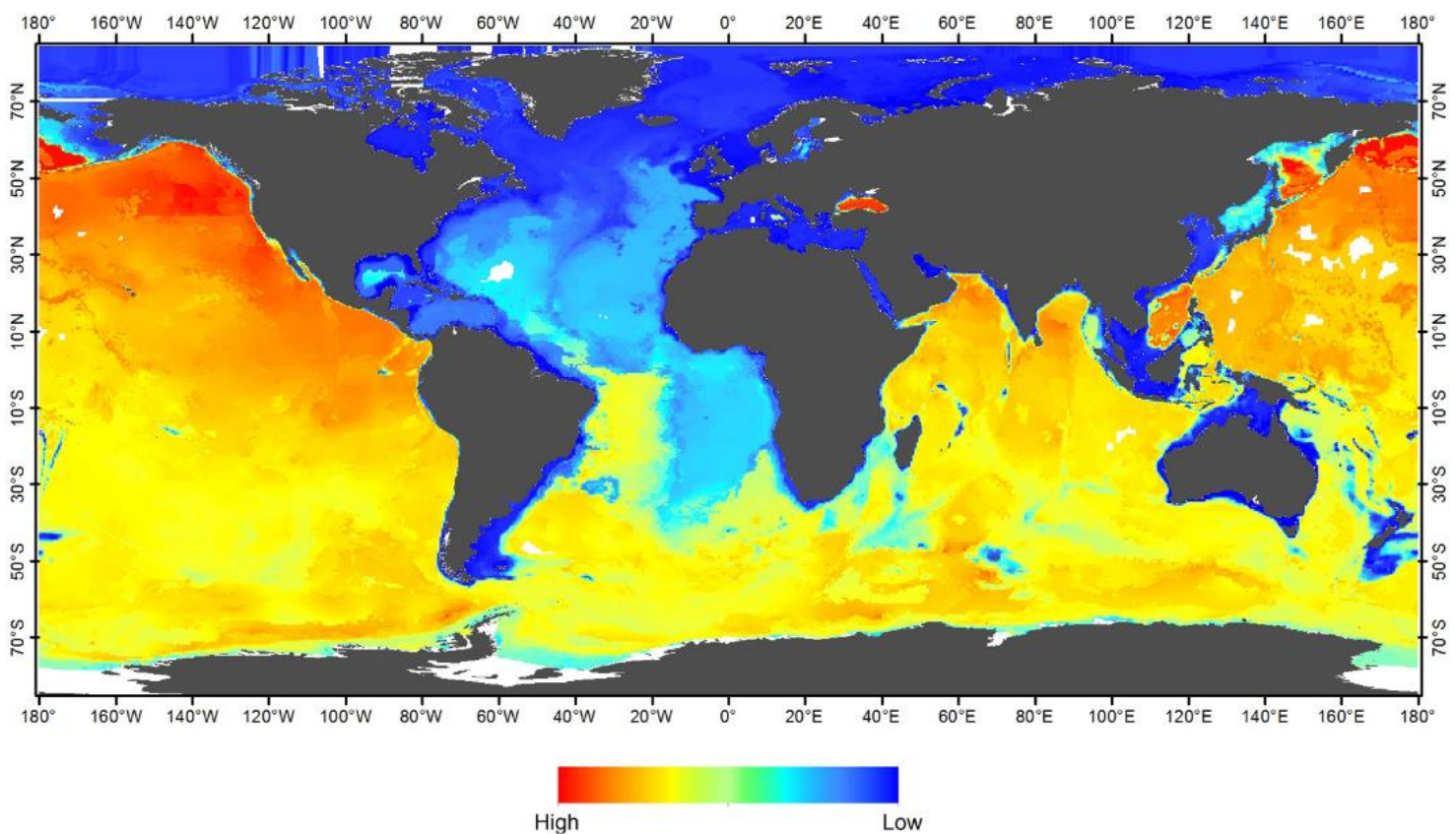

Figure A43. Dissolved $\mathrm{O}_{2}$

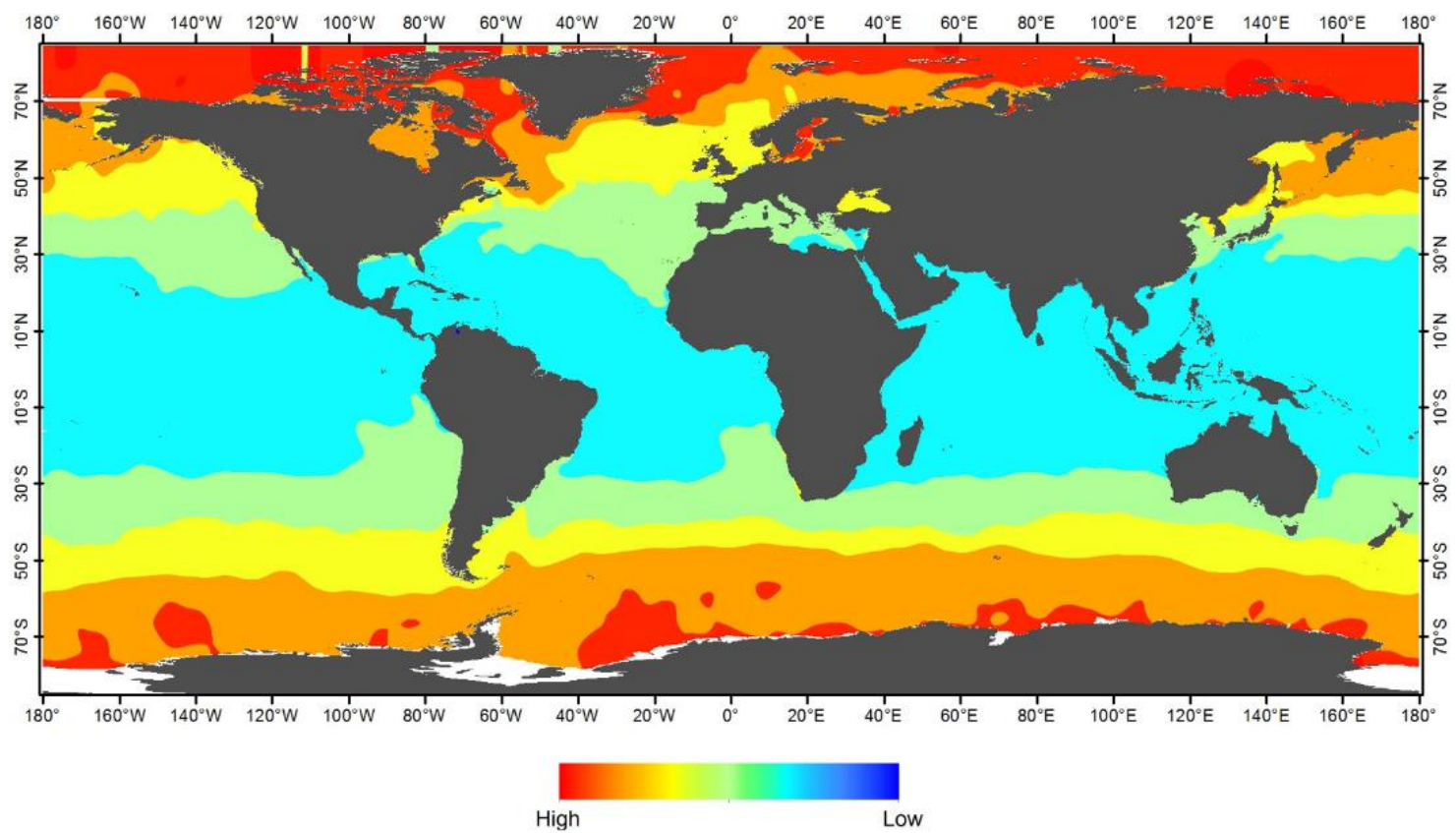


Earth Syst. Sci. Data Discuss., https://doi.org/10.5194/essd-2018-64

Manuscript under review for journal Earth Syst. Sci. Data

Discussion started: 27 July 2018

(c) Author(s) 2018. CC BY 4.0 License.

(c) (1)

Figure A44. Seabed Dissolved $\mathrm{O}_{2}$

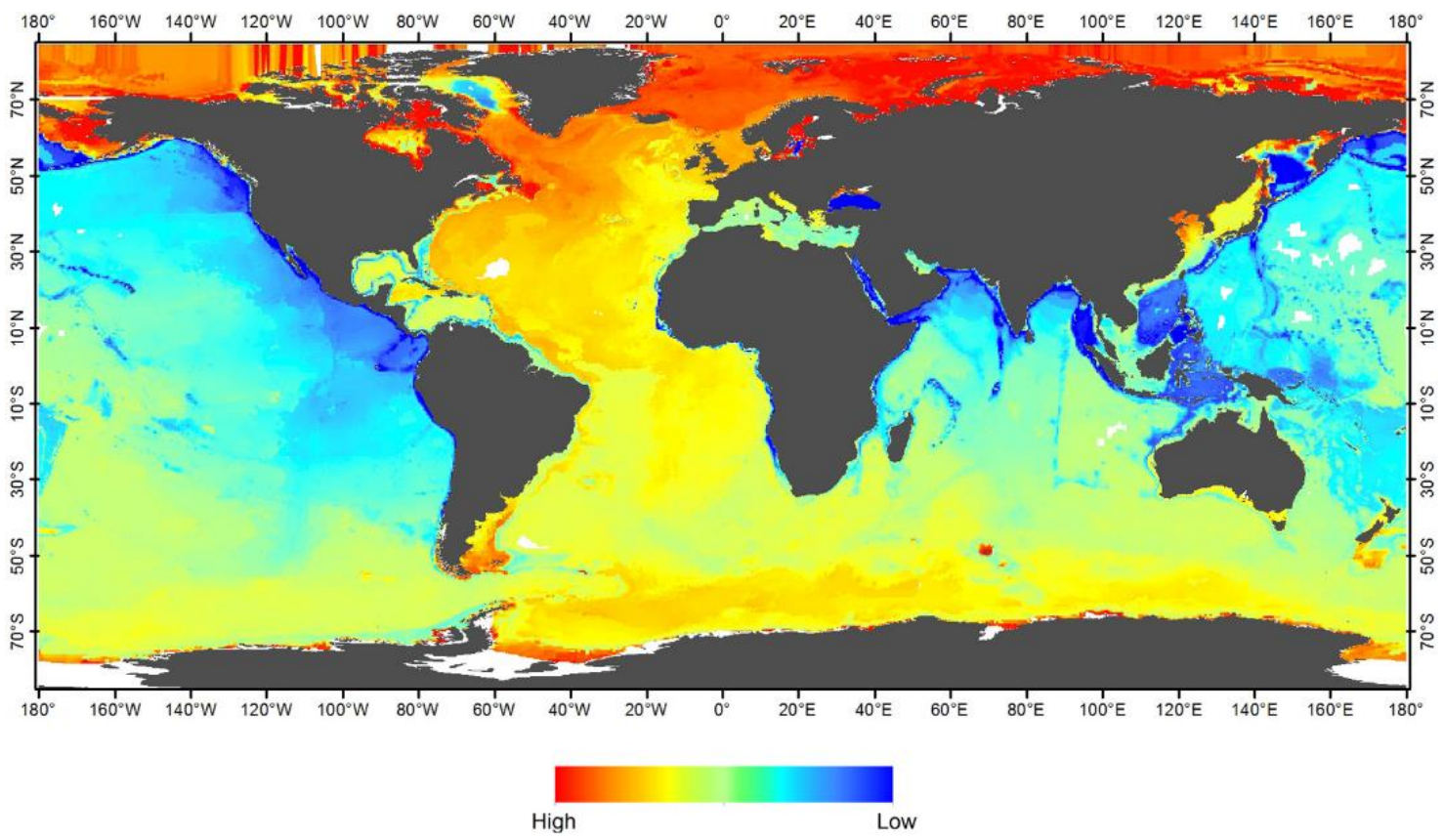

Figure A45. Saturated $\mathrm{O}_{2}$

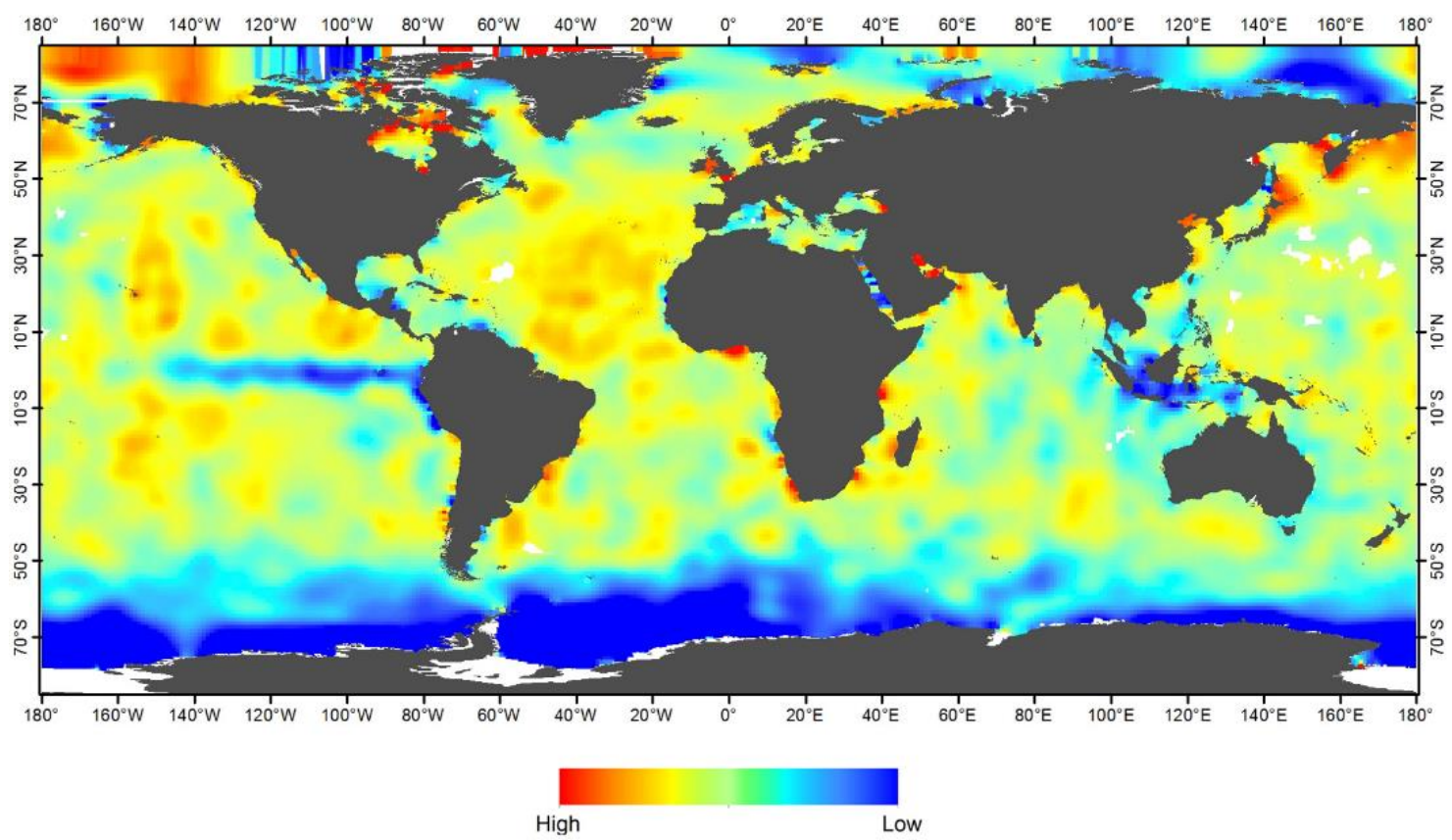


Earth Syst. Sci. Data Discuss., https://doi.org/10.5194/essd-2018-64

Manuscript under review for journal Earth Syst. Sci. Data

Discussion started: 27 July 2018

(c) Author(s) 2018. CC BY 4.0 License.

(c) (1)

Figure A46. Seabed Utilized $\mathrm{O}_{2}$

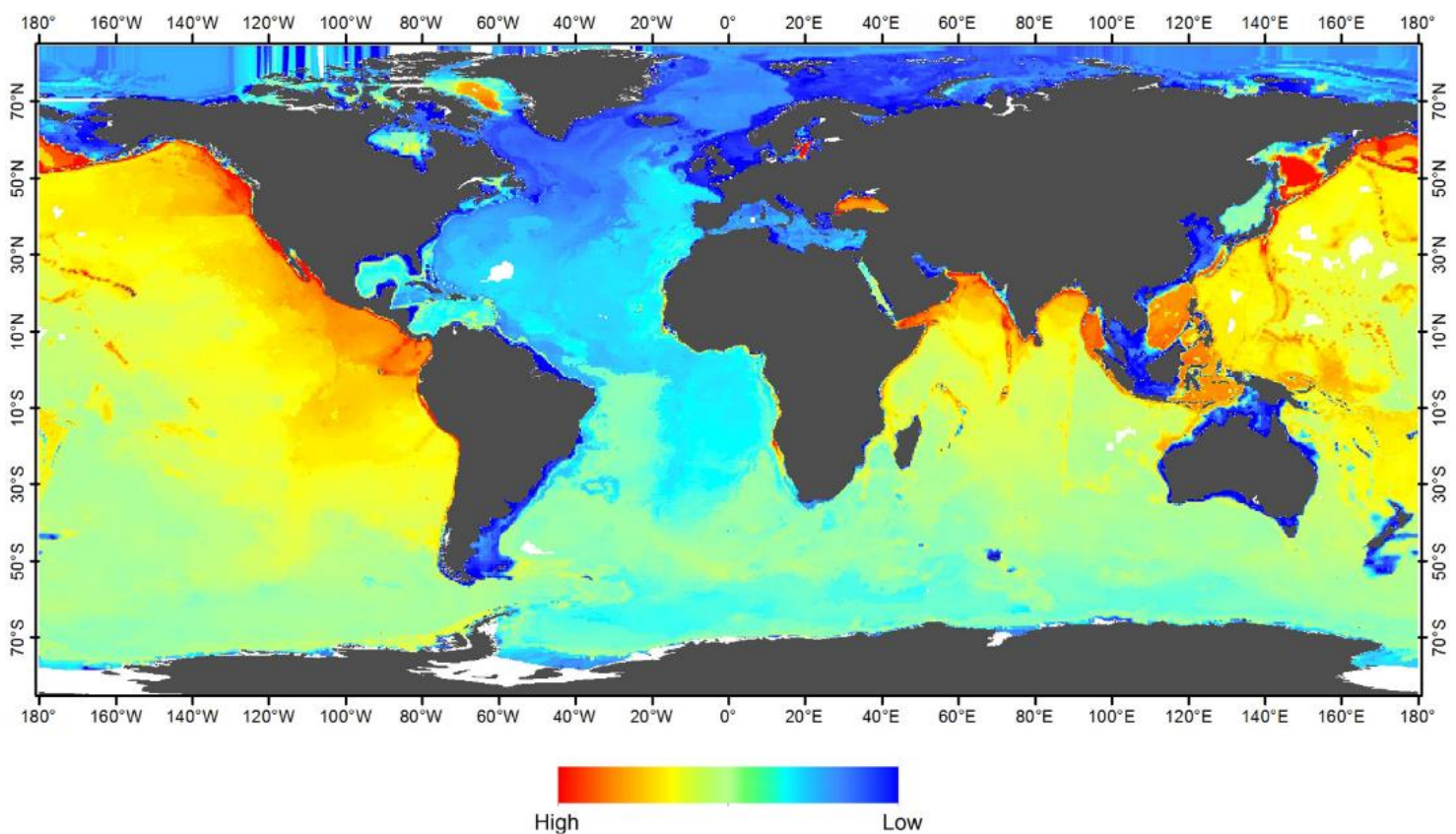

Figure A47. Particulate Organic Carbon

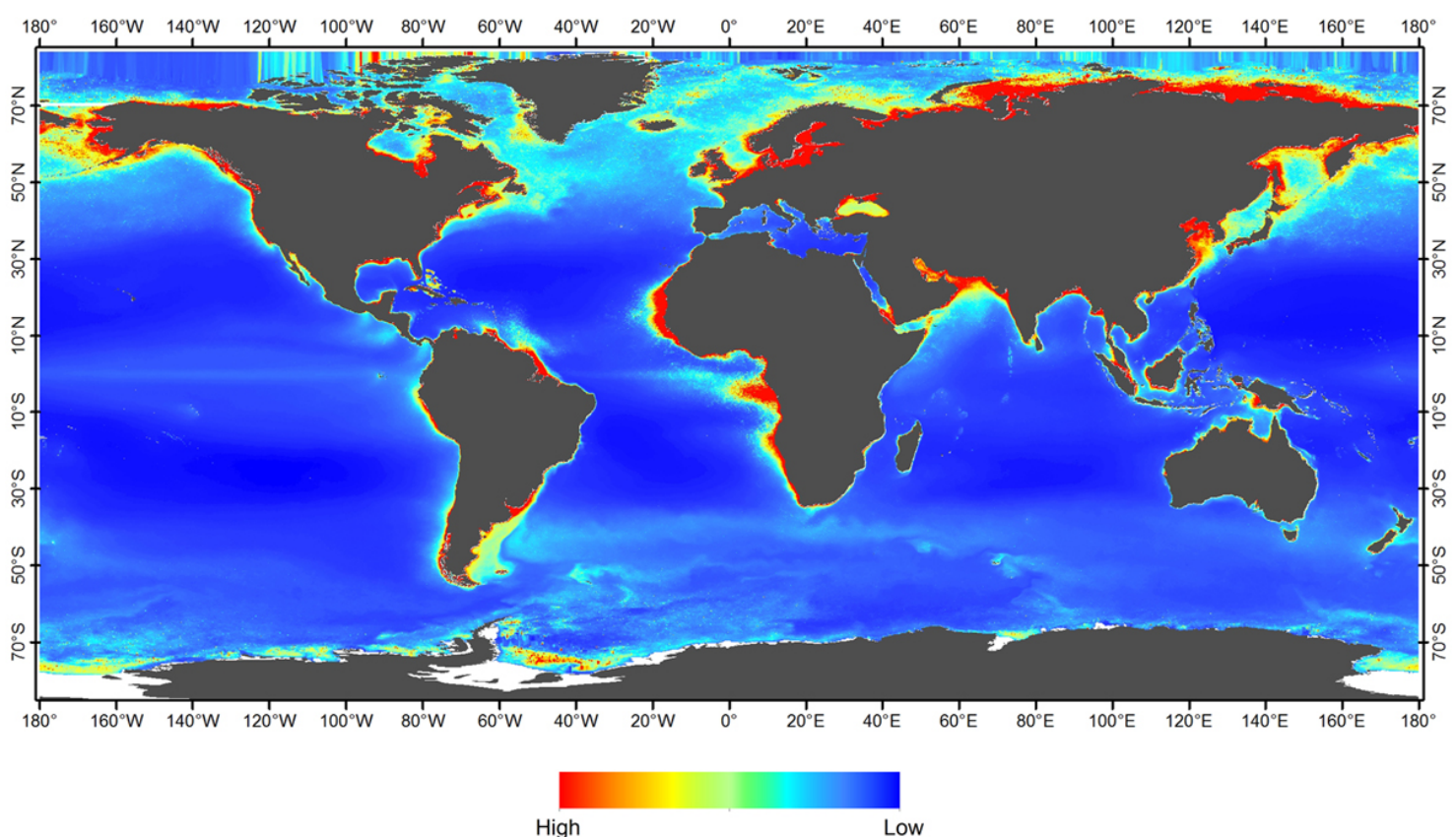


Earth Syst. Sci. Data Discuss., https://doi.org/10.5194/essd-2018-64

Manuscript under review for journal Earth Syst. Sci. Data

Discussion started: 27 July 2018

(c) Author(s) 2018. CC BY 4.0 License.

(c) (i)

Figure A48. Particulate Inorganic Carbon

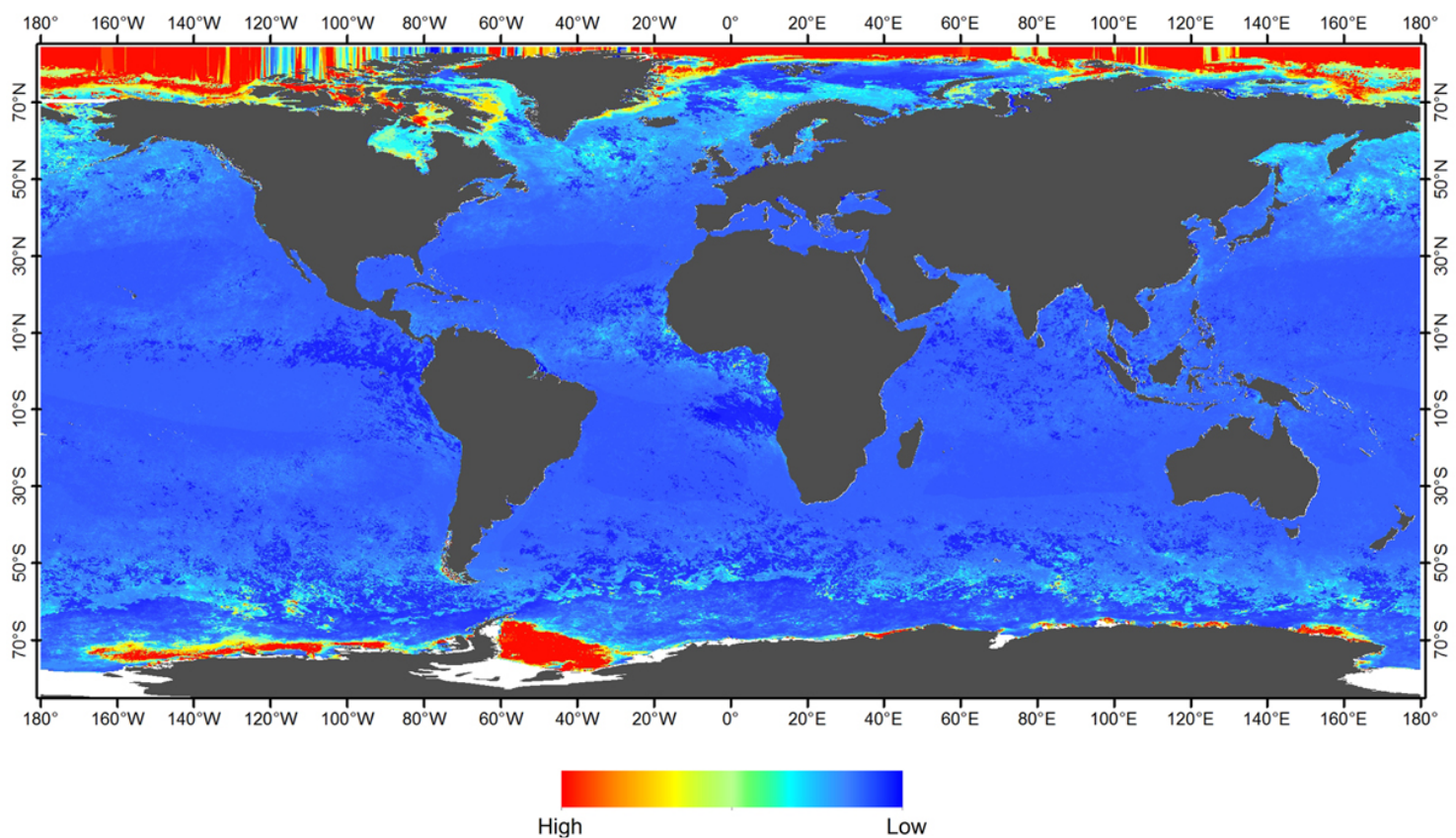


Earth Syst. Sci. Data Discuss., https://doi.org/10.5194/essd-2018-64

Manuscript under review for journal Earth Syst. Sci. Data

Discussion started: 27 July 2018

(c) Author(s) 2018. CC BY 4.0 License.

(c) (i)

Past (Last Glacial Maximum, 22 mya)

Figure A49. Depth

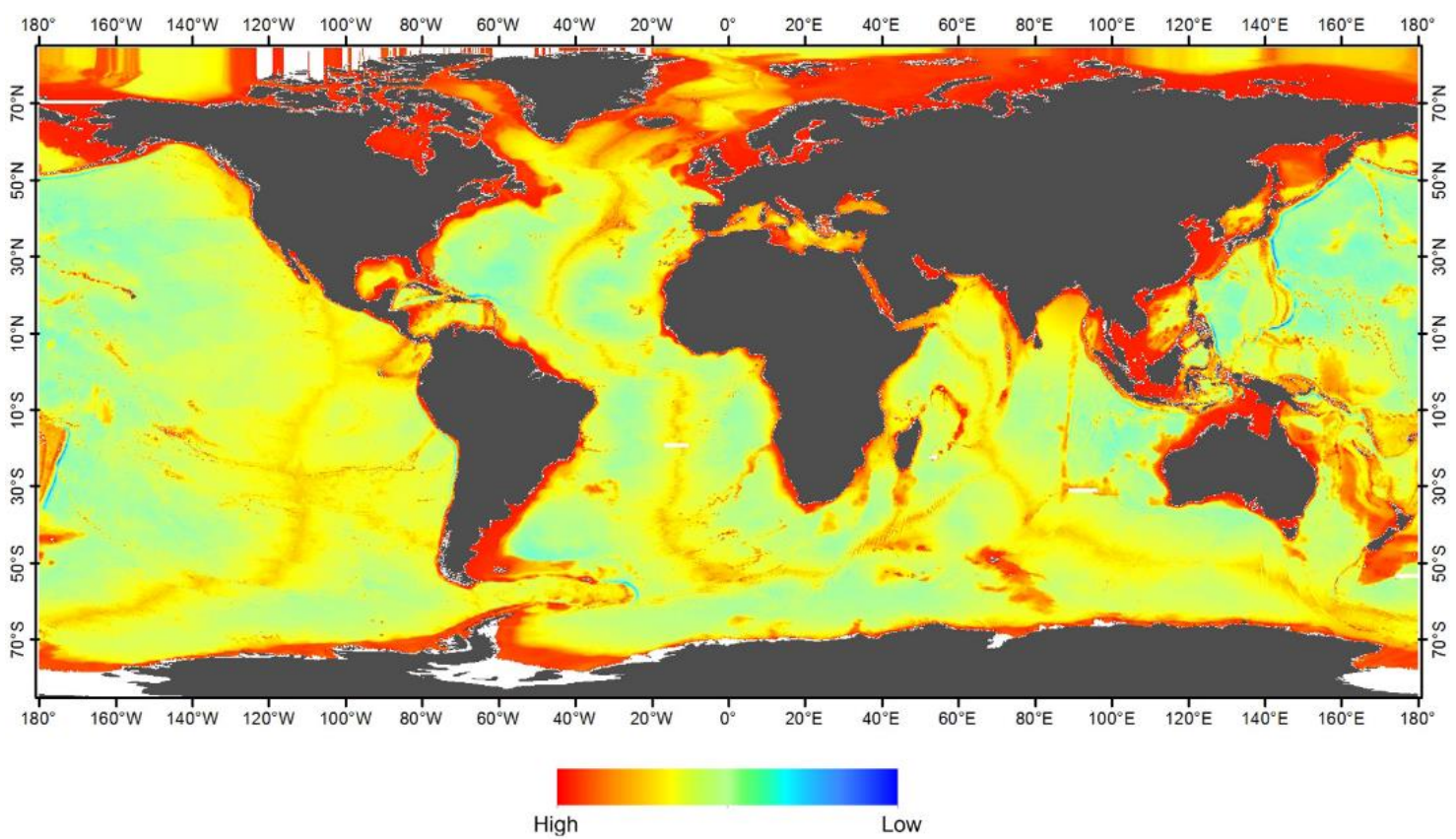

Figure A50. Temperature

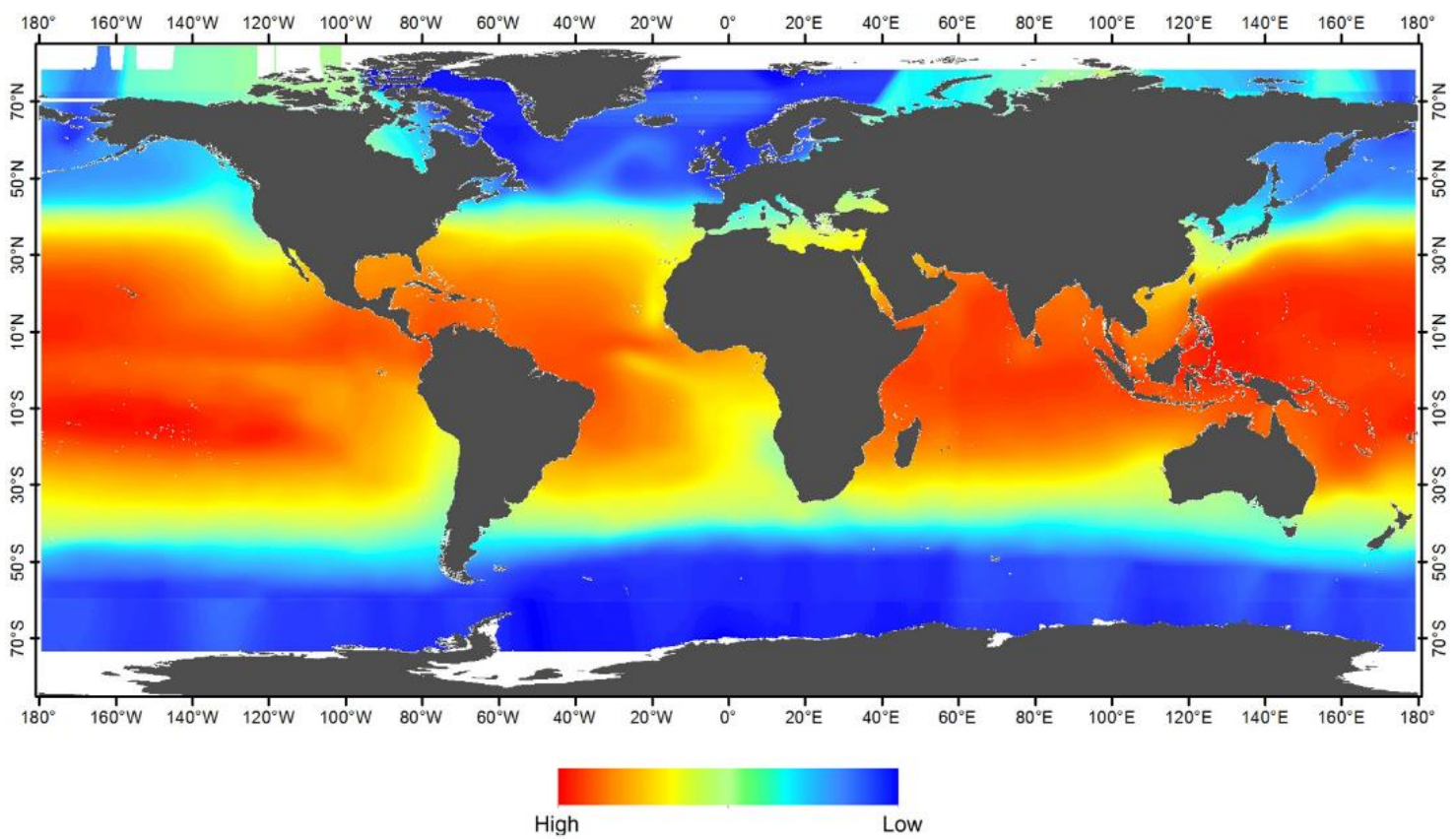


Earth Syst. Sci. Data Discuss., https://doi.org/10.5194/essd-2018-64

Manuscript under review for journal Earth Syst. Sci. Data

Discussion started: 27 July 2018

(c) Author(s) 2018. CC BY 4.0 License.

(c) (1)

Figure A51. Salinity

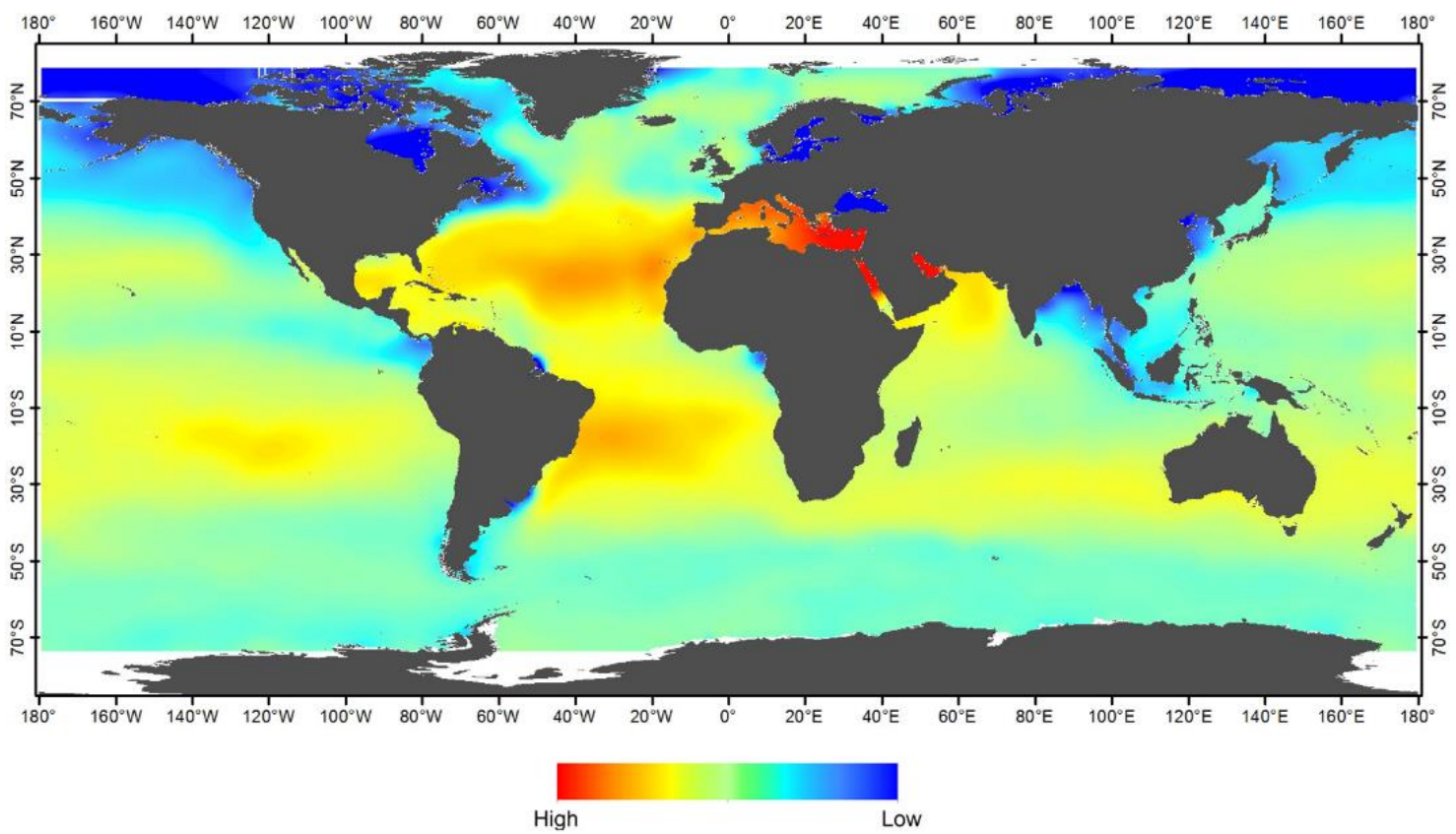

Figure A52. Ice Thickness

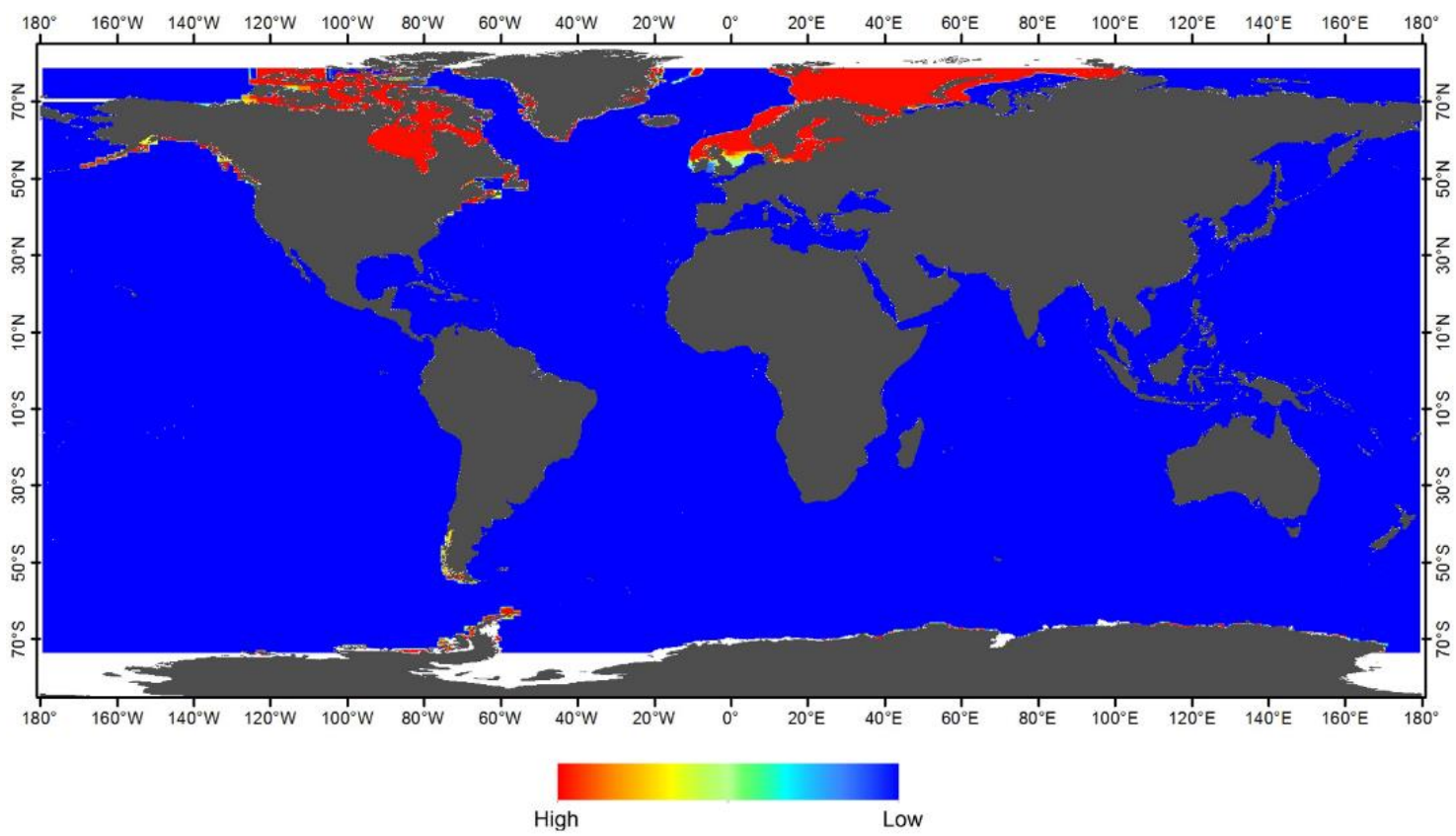


Earth Syst. Sci. Data Discuss., https://doi.org/10.5194/essd-2018-64

Manuscript under review for journal Earth Syst. Sci. Data

Discussion started: 27 July 2018

(c) Author(s) 2018. CC BY 4.0 License.

(c) (i)

\section{Future (Year 2100)}

Figure A53. Temperature A1B Scenario

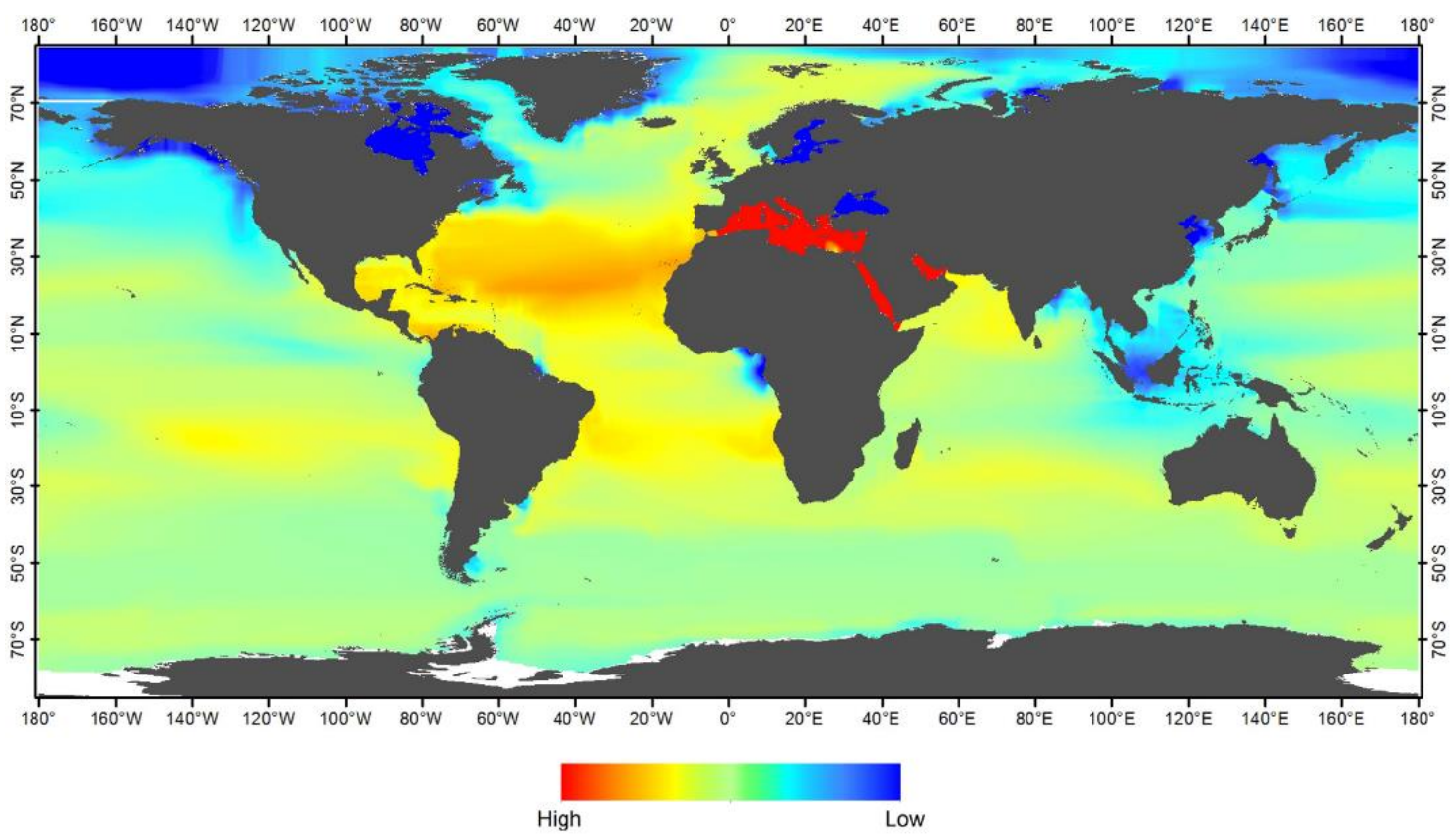

Figure A54. Temperature A2 Scenario

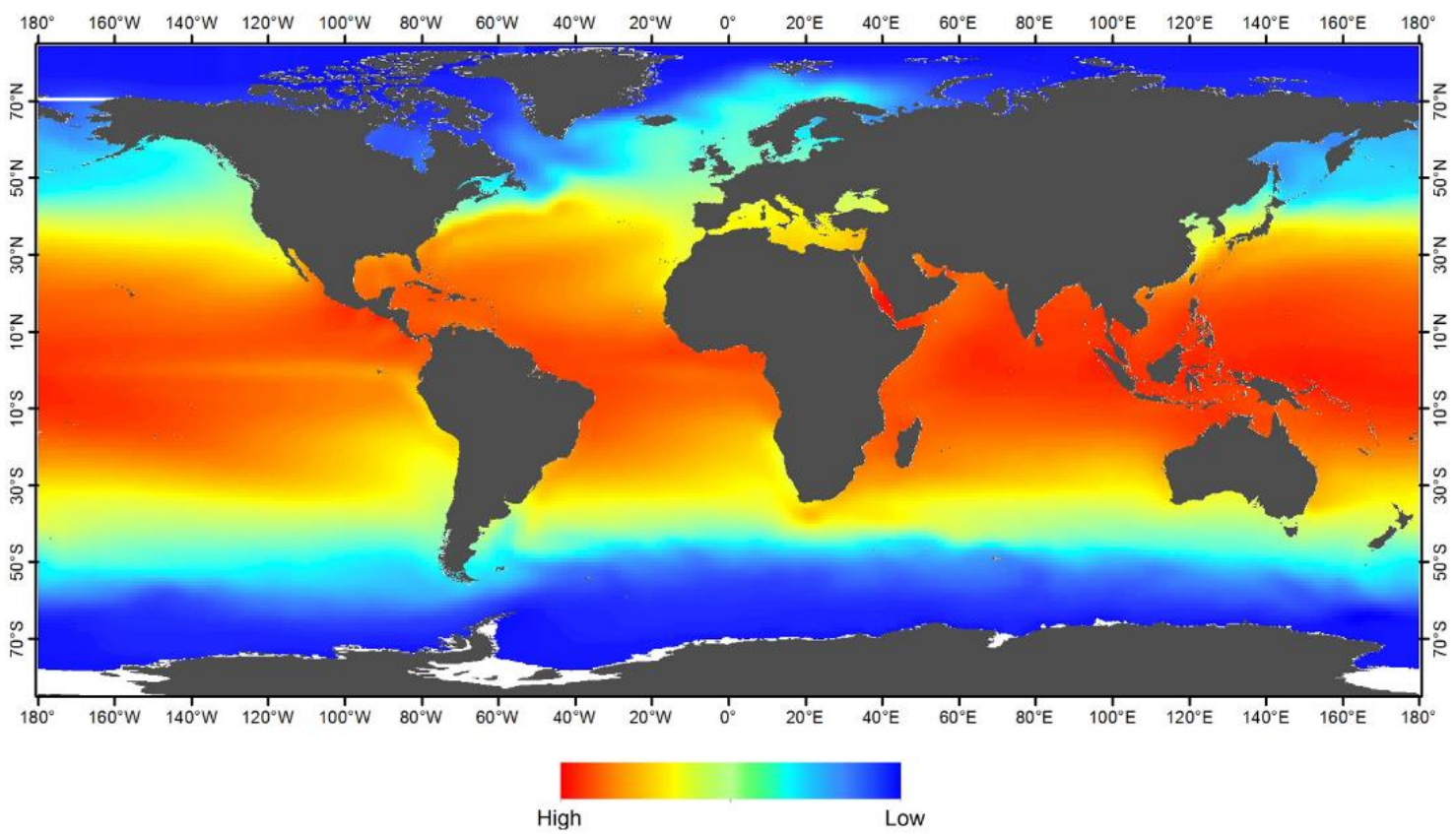


Earth Syst. Sci. Data Discuss., https://doi.org/10.5194/essd-2018-64

Manuscript under review for journal Earth Syst. Sci. Data

Discussion started: 27 July 2018

(c) Author(s) 2018. CC BY 4.0 License.

(c) (i)

Figure A55. Seabed Temperature

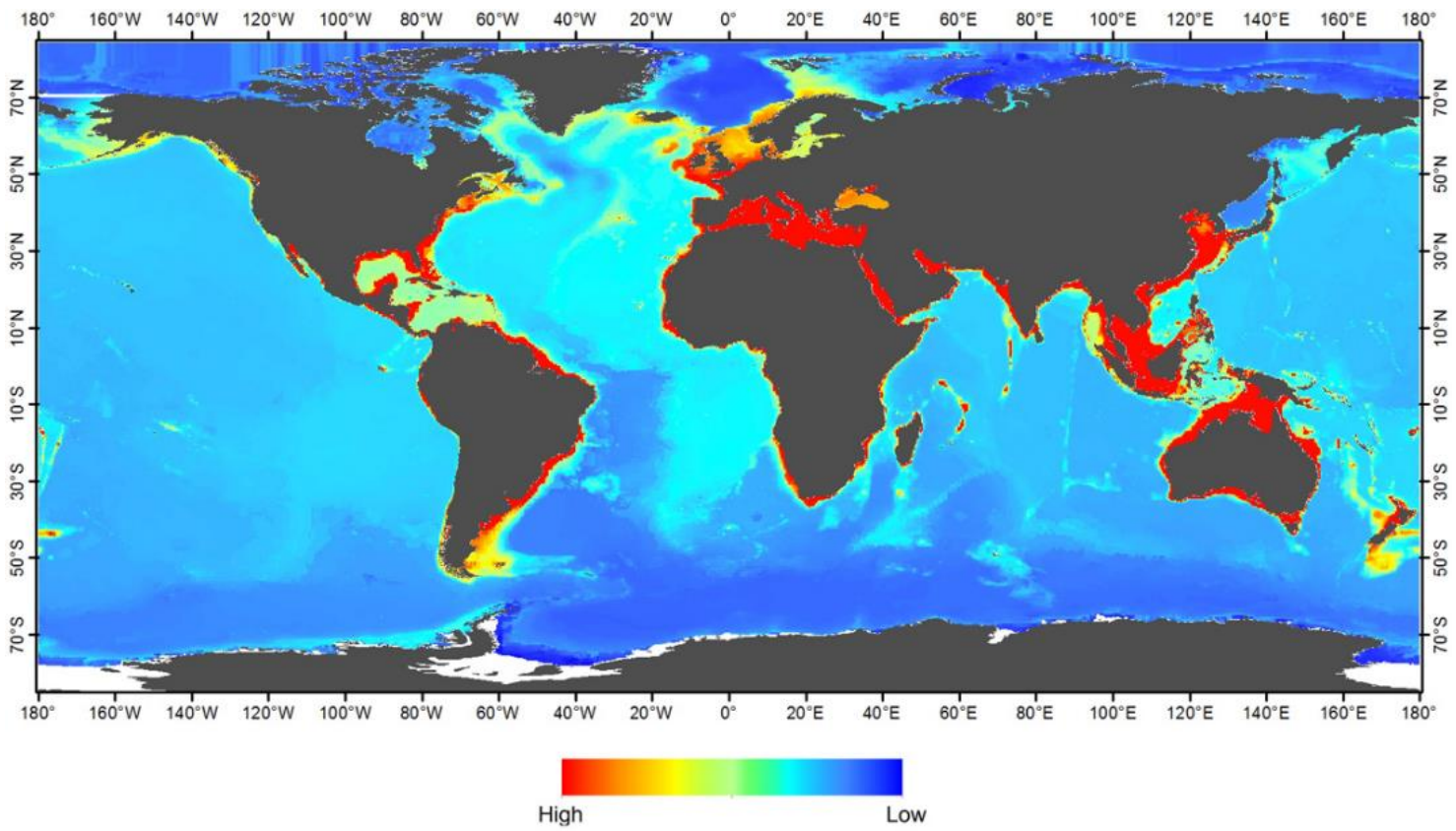

Figure A56. Salinity A1B Scenario

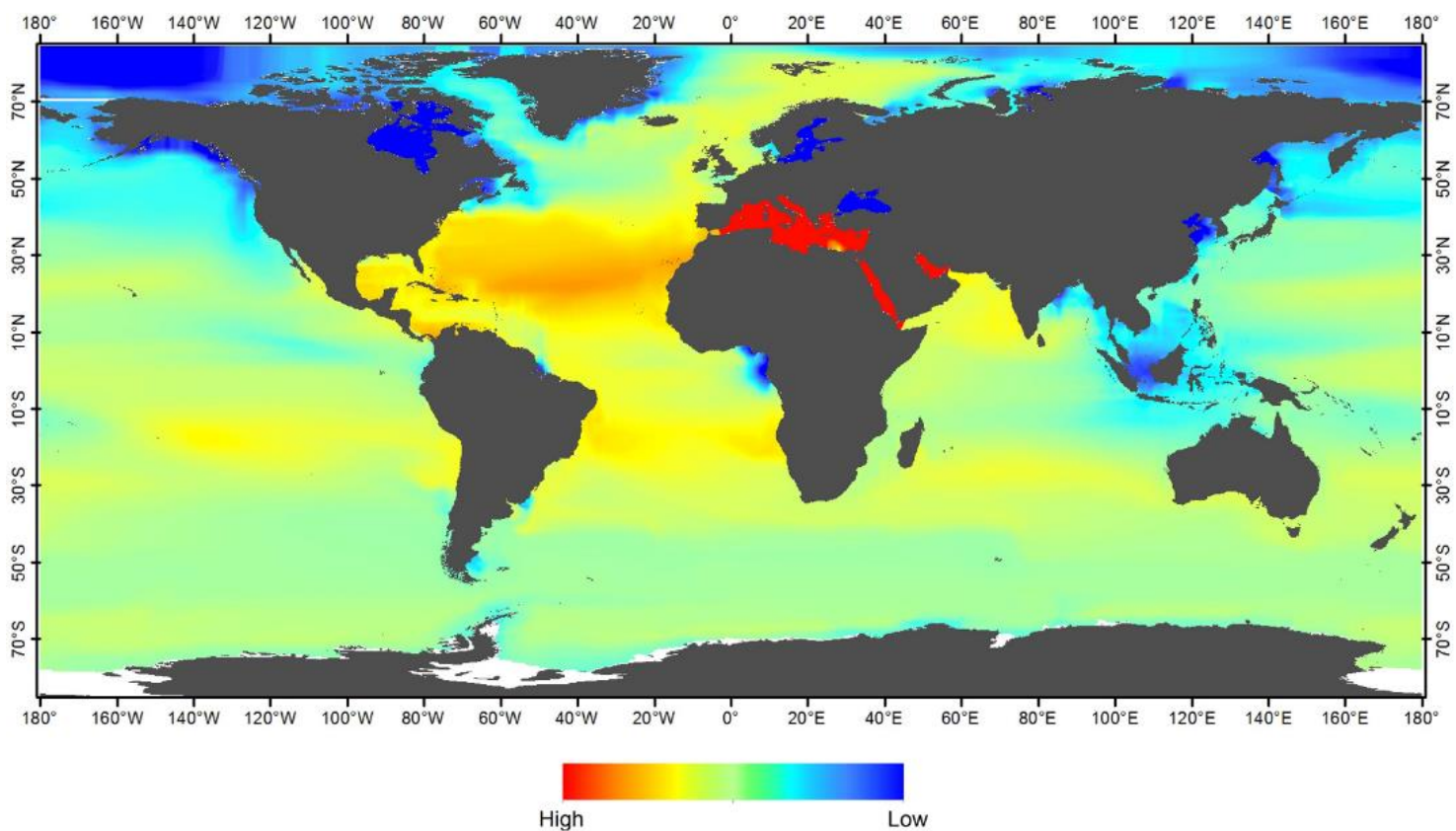


Earth Syst. Sci. Data Discuss., https://doi.org/10.5194/essd-2018-64

Manuscript under review for journal Earth Syst. Sci. Data

Discussion started: 27 July 2018

(c) Author(s) 2018. CC BY 4.0 License.

(c) (i)

Figure A57. Salinity A2 Scenario

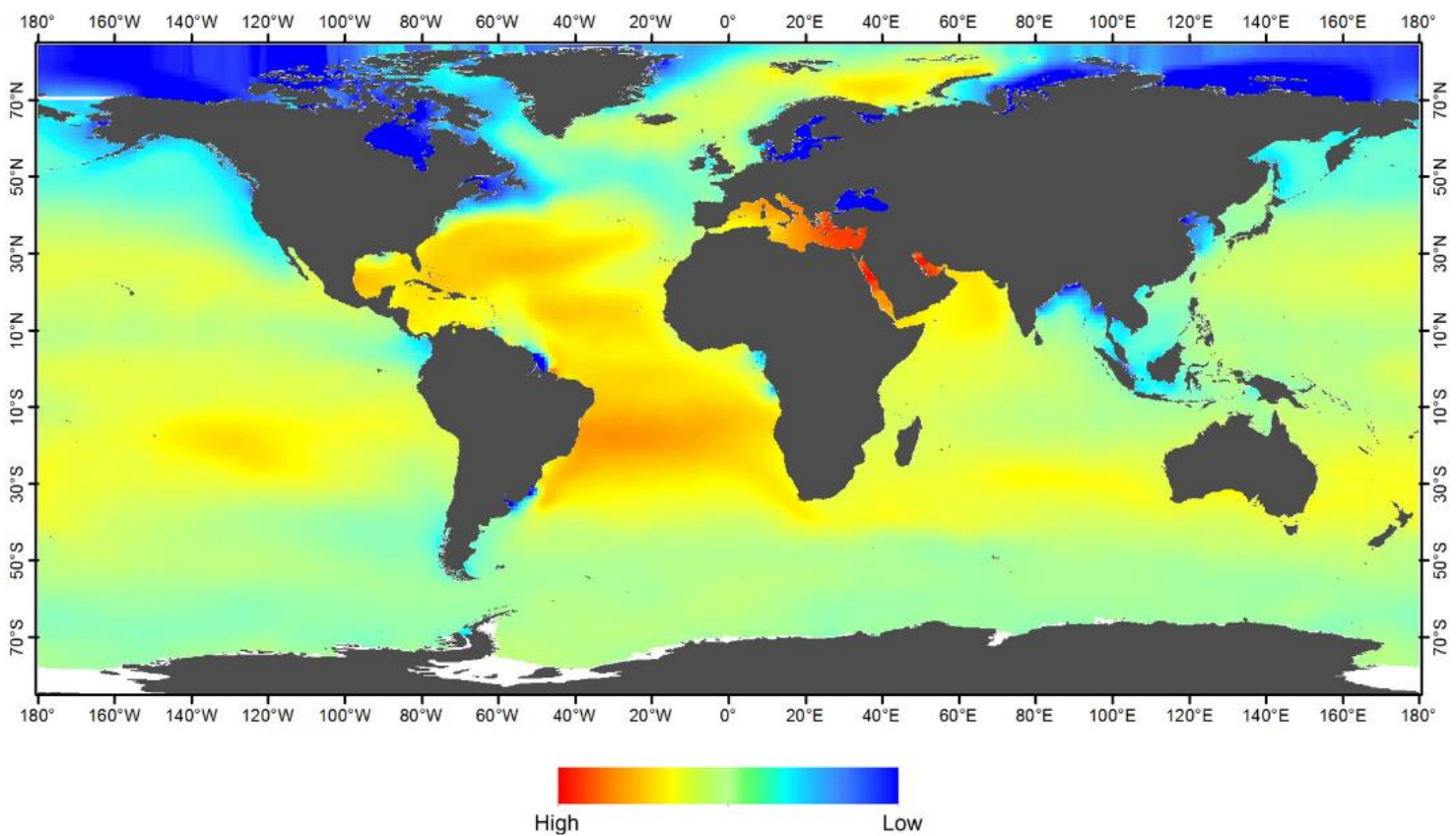

Figure A58. Seabed Salinity

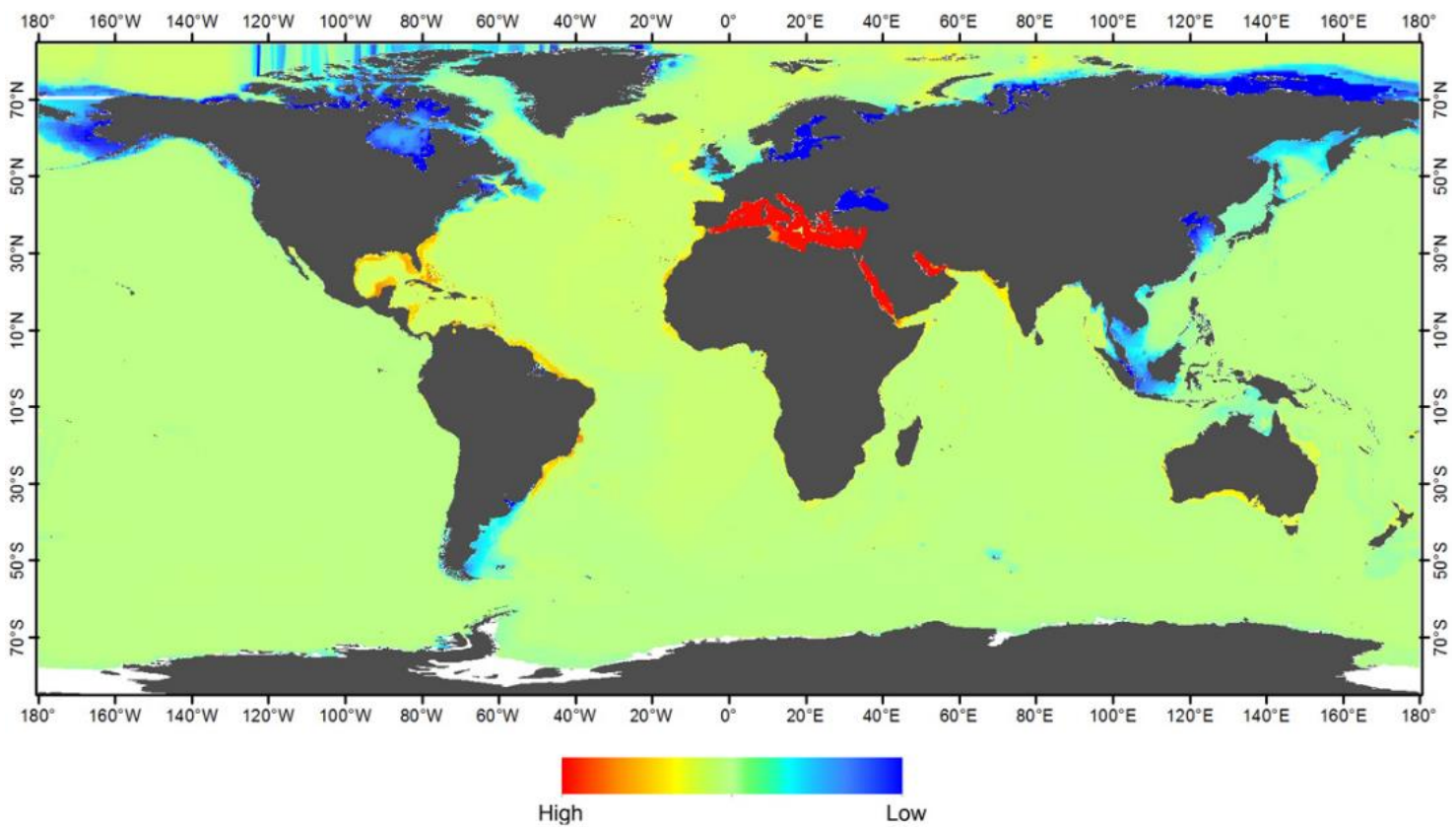


Earth Syst. Sci. Data Discuss., https://doi.org/10.5194/essd-2018-64

Manuscript under review for journal Earth Syst. Sci. Data

Discussion started: 27 July 2018

(c) Author(s) 2018. CC BY 4.0 License.

(c) (i)

Figure A59. Primary Productivity

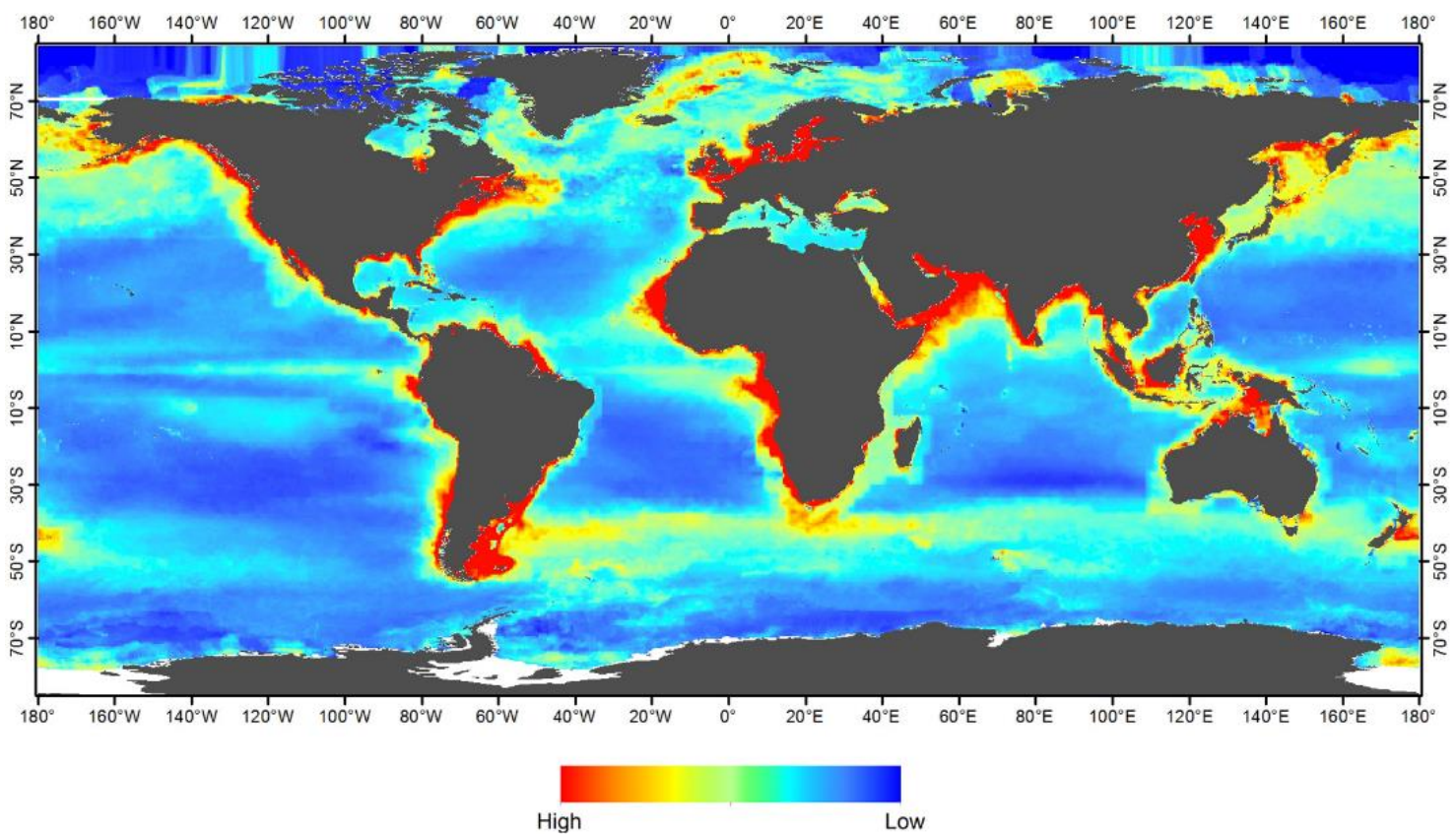

Figure A60. Ice concentration

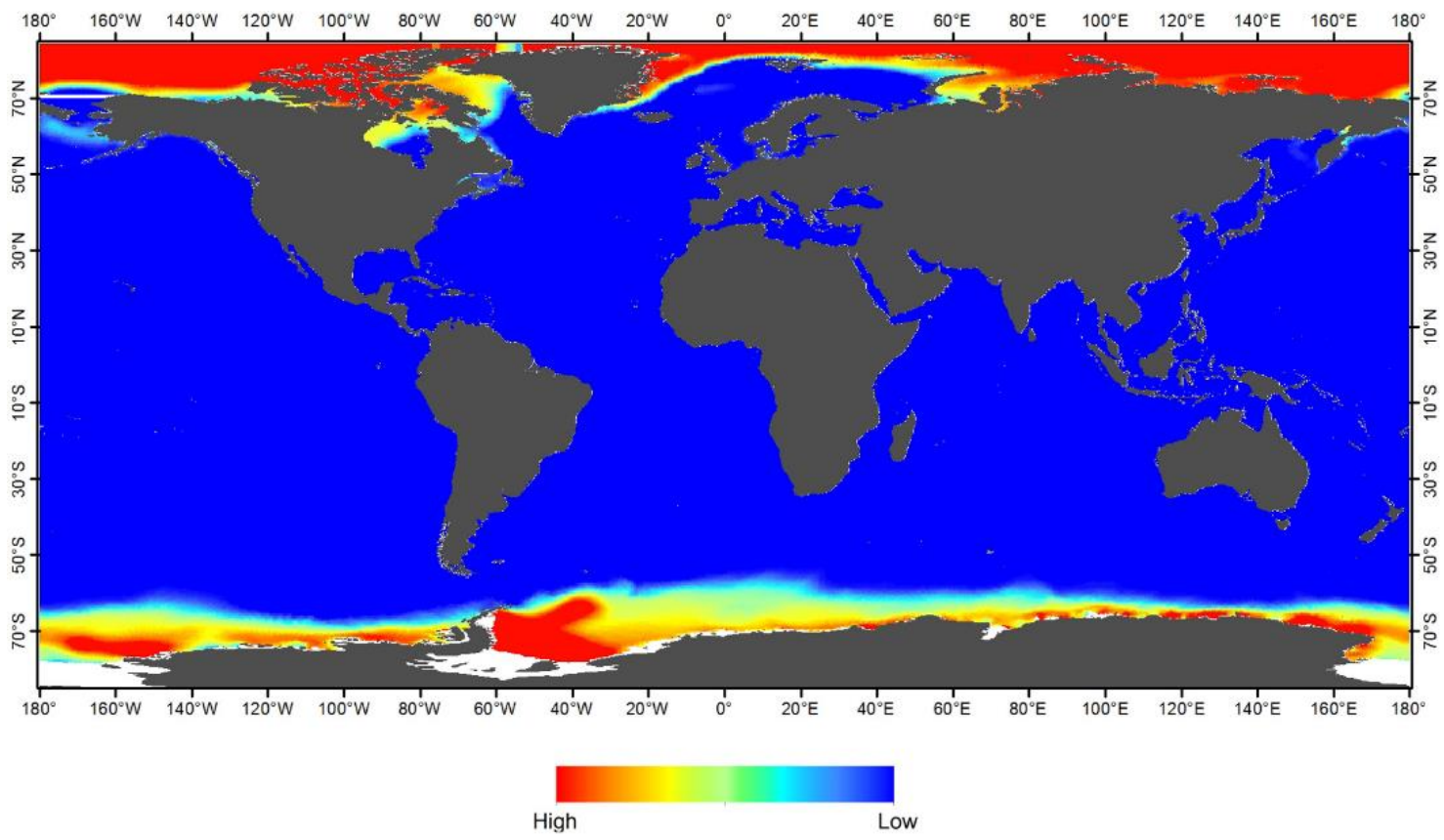

